UNIVERSIDADE DE SÃO PAULO

FACULDADE DE FILOSOFIA, LETRAS E CIÊCIAS HUMANAS DEPARTAMENTO DE LETRAS CLÁSSICAS E VERNÁCULAS PROGRAMA DE PÓS-GRADUAÇÃO EM LITERATURA PORTUGUESA

\title{
A Ordem e o Caos: Plauto e José Saramago.
}


NEFATALIN GONÇALVES NETO

A ORDEM E O CAOS: PLAUTO E JOSÉ SARAMAGO.

Dissertação final apresentada ao Programa de Pós-Graduação em Literatura Portuguesa do Departamento de Letras Clássicas e Vernáculas da Faculdade de filosofia, Letras e Ciências Humanas da Universidade de São Paulo como requisito parcial para obtenção do grau de mestre em Literatura Portuguesa.

Orientadora: Profa. Dra. Lílian Lopondo.

São Paulo 
NEFATALIN GONÇALVES NETO

A ORDEM E O CAOS: PLAUTO E JOSÉ SARAMAGO.

Dissertação apresentada ao programa de PósGraduação em Literatura Portuguesa do Departamento de Letras Clássicas e Vernáculas da Faculdade de filosofia, Letras e Ciências Humanas da Universidade de São Paulo para obtenção do título de Mestre em Literatura Portuguesa, sob a orientação da Prof ${ }^{a}$. Dra. Lílian Lopondo.

Aprovada em $/ 2011$.

BANCA EXAMINADORA

Dra. LÍLIAN LOPONDO

Universidade de São Paulo

Dra. RAQUEL DE SOUZA RIBEIRO

Universidade de São Paulo

Dra. AURORA GEDRA RUIZ ALVAREZ

Universidade Presbiteriana Mackenzie 
À Deus, caminho, conforto e fortaleza sempre.

Aos meus pais, Carlos Gonçalves e Maria Auxiliadora Alves Gonçalves, por serem o que são e por fazer o que fazem por mim.

À Lilian Lopondo, minha orientadora, pelo apoio e confiança nestes três anos de caminhada e aprendizagens. 


\section{AGRADECIMENTOS}

\section{Só um lembrete...}

A vida é o dever que nós trouxemos para fazer em casa.

Quando se vê, já são seis horas!

Quando se vê, já é sexta-feira...

Quando se vê, já terminou o ano...

Quando se vê, perdemos o amor da nossa vida.

Quando se vê, já se passaram cinqüenta anos!

Agora é tarde demais para ser reprovado.

Se me fosse dado, um dia, outra oportunidade, eu nem olhava o relógio.

Seguiria sempre em frente e iria jogando, pelo caminho, a casca dourada e inútil das horas.

\section{Mário Quintana}

Esta dissertação é fruto de um trabalho polifônico que, com certeza, traz muito de minha vida sendo, muitas vezes, a história desta própria até o momento. Impossível agradecer aqui a todos aqueles que comigo conviveram, seja por conta da dissertação - que colaboraram para que ela fosse o que é -, seja por apoiarem ou acreditarem nela aturando-me e/ou ouvindo minhas inúmeras (e muitas vezes inúteis, chatas e despropositadas) proposições. Os nomes seriam demasiados, escapam na hora de relacionar todas as vozes que se cruzaram na composição desse texto. A tarefa de preparar a lista jamais teria um fim. O que segue é apenas um ponto de partida, uma espécie de relação daqueles que a memória nos permitiu captar.

À Deus, autor da vida e doador da inteligência e sabedoria, que me concedeu o privilégio de vencer mais esta etapa de grande importância em minha vida.

Aos meus familiares que entendiam - ou não - minhas angústias, ausências e a falta de tempo para as demais coisas da vida. Pela energia, apoio, amor, ideias e principalmente por me darem a vida, agradeço aos meus pais, únicos e primeiros grandes iniciadores deste trabalho, a bons 27 anos atrás e que, a oito anos, esperam que eu termine essa loucura toda e volte a viver em casa, na paz e no sossego do lar.

À Natália Bortolacci (por fazer minha matricula na pós-graduação por procuração quando eu ainda nem sonhava com tudo isso), Sueli e Maria Carli (porque acreditarem no meu sonho), aos amigos e professores do CEFAM de Araçatuba (os que primeiro 
acreditaram nos delírios que eu tinha), que me apoiaram e me ajudaram a chegar até aqui. Ficam registrados em especial os nomes de Maria da Graça Palma Picollin e Rosa Garrutti pelo ensino, confiança e amizade; e ao $4^{\circ}$ ano $\mathrm{D}$, sala que me despertou para os estudos sobre Literatura. Ao amigo Eder Rafael de Araújo, pelas intermináveis voltas no quarteirão e pela paciência e auxilio em cada detalhe e vírgula aqui escrito. À Camila pela (im)paciência de todos os dias nesses longos anos.

À UNESP/Assis, nas pessoas de seus professores, que me iniciaram no campo das Letras e me deram a formação base para que eu chegasse até aqui. Dentre eles uma menção especial à Luis Roberto Velloso Cairo, Sandra Aparecida Ferreira, João Luis Tápias Ceccantini, Ana Maria Domingues de Oliveira, Rubens Pereira dos Santos, Odil José de Oliveira Filho e Igor Rossoni. Aos professores de Latim da mesma Universidade nos nomes de Mirtes Rodrigues, Cláudia Valéria Penavel Binato e Enio Aloísio Fonda, que me ensinaram com tanto afinco o amor pela língua latina e seus múltiplos campos de estudos.

As diretoras Gisele Lopes Rodrigues e Senise Camargo Lima Yaslle, e às coordenadoras Marcia Khnaiffes e Maria Ines Lima Sartori que, durante esse período, muito contribuiram com seus esforços para que eu chegasse até aqui. À Bel, pelos galhos quebrados e pelas ajudas sempre oportunas. E aos secretários da Educação de Assis Professor Rubens Cruz e Professora Ângela das Neves Canassa, por acreditarem no meu potencial e me permitirem o afastamento da sala de aula.

À USP, que demonstrou cultura e grande acolhimento ao me receber em seu curso de pós-graduação, sendo eu oriundo de outra universidade, o que permitiu um passo significativo em minha carreira acadêmica. Em especial, aos professores doutores Horácio Costa, Lilian Jacoto e Norma Seltzer Goldstein pelo conhecimento partilhado em suas aulas iluminadoras.

Ao Departamento de Letras Clássicas e Vernáculas da FFLCH, particularmente à secretária Dayane, pelo envolvimento, apoio e incentivo em todos os momentos a que precisei recorrer a seus auxílios. Aos funcionários da biblioteca Florestan Fernandes (FFLCH/USP) pela atenção, auxílio e disponibilidade em sempre ajudar nos momentos mais apurados da pesquisa. Também aos funcionários e funcionárias da biblioteca da UNESP/Assis pela ajuda sempre tão consistente em minhas necessidades, além do incentivo, apoio, fornecimento de materiais, pela postura sempre aberta de servir e de colaborar com meu crescimento pessoal. 
À Prof ${ }^{a}$. Dra. Raquel de Sousa Ribeiro, pelas disciplinas ministradas no curso de pós-graduação em Literatura Portuguesa e pelo conhecimento que tanto dedicou aos alunos e especialmente a mim. Agradeço também às indicações tão importantes no momento da Qualificação de Mestrado. À professora convidada Dra. Aurora Gedra Ruiz Alvarez, pela leitura sensível e significativos apontamentos apresentados no Exame de Qualificação, auxílio que contribuiu para melhor delinear os rumos e o burilamento deste texto.

À Profa. Maria Helena Fioravante Peixoto pelos maravilhosos espaços de interlocução discursiva proporcionados (virtuais e reais), somados às dicas, correções e, principalmente, pelas maravilhosas conversas sobre a literatura, a arte e a vida.

À Profa. Dra. Lilian Lopondo, a quem devo enorme gratidão por ter me acompanhado durante esses anos, por suportar com deveras paciência minhas inquietudes, dúvidas, problemas e até as birras teóricas. A ela, que atuou como grande orientadora e mestra, revelando-se grande amiga e com zelo, cuidado, paciência e dedicação acreditou nessa dissertação e a conduziu maravilhosamente bem. Para além da orientação, por ter me ensinado muitíssimo tanto no campo da Literatura quanto no campo da produção textual.

Em especial, àqueles que por certo não possuem o nome citado aqui, mas que, de uma forma ou de outra, me ajudaram, seja em digitar textos, fazer a revisão, por sugerir a reescritura de alguns parágrafos, por fazer e postar fotocópias, por terem sido muitas vezes mais do que professores, mais do que amigos. Enfim, pessoas de perto e de longe (algumas que fisicamente eu ainda não tive a oportunidade conhecer) deixo o meu muito obrigado, pois sei que palavras sao poucas para expressar o que sinto e como sou grato a cada um, pessoas que me fazem cada vez mais aprender a ser mestre aprendendo.

À FAPESP pela bolsa de Iniciação Científica, cujo resultado abriu caminho para o tema dessa presente dissertação. À CAPES, pela bolsa concedida (elemento essencial em meu desenvolvimento e amadurecimento do conteúdo pesquisado).

Não obstante o suporte e contribuição de tantos que aqui constam (e muitos outros que já a memória não foi capaz de registrar) e, consciente de que a forma do trabalho está muito aquém da ajuda que de cada um recebi, desejo expressar que quaisquer erros e equívocos remanescentes no trabalho são de minha total responsabilidade, mas que o texto sem a colaboração deles, não teria sido o mesmo. 
UM SONHO

Num deserto lugar do Irã há uma torre de pedra não muito alta, mas sem porta nem janela. No único cômodo (seu piso é de terra e tem a forma do círculo) há uma mesa de madeira e um banco. Nessa cela circular, um homem que se parece comigo escreve em caracteres que não compreendo um longo poema sobre um homem que noutra cela circular escreve um poema sobre um homem que noutra cela circular... O processo não tem fim e ninguém poderá ler o que os prisioneiros escrevem.

Jorge Luis Borges 
GONÇALVES NETO, Nefatalin. A Ordem e o Caos: Plauto e José Saramago. Dissertação (Mestrado em Literatura Portuguesa). Faculdade de Filosofia Letras e Ciências Humanas. São Paulo: Universidade de São Paulo, 2010.

\section{RESUMO}

A temática do duplo é assunto recorrente dentro da Literatura desde tempos primordiais, sendo encontrada nela diferentes formas de constituição da duplicidade. O presente trabalho tem como objetivo analisar as obras Amphytruo, do escritor latino Plauto e $O$ Homem Duplicado, do escritor português José Saramago por meio da investigação do tema do duplo presente nas duas obras em questão. Dessa forma, o diálogo entre as obras se estabelece por meio do mito de Anfitrião, que é retomado pelos dois escritores transfigurado segundo a intenção de cada um. Nosso proposito é, amparados pela literatura comparada, investigar como o tema do duplo é tratado em cada obra, para qual direcionamento a crise identitária imanente em cada uma aponta e examinar quais mecanismos intertextuais cada escritor se vale para compor suas obras retomando/renovando seu protótipo. A análise das referidas obras tem, como apoio teórico, os estudos bakhtinianos sobre o dialogismo e os elementos intertextuais de acréscimo, supressão, inversão e deslocamento. Por meio da análise empreendida, verificamos como os autores retomam o tema do duplo para abordar a cisão da identidade dos sujeitos de suas épocas. Do estudo podemos apreender que a literatura clássica, por ser monolítica, não assume dimensões dramáticas, diferente da literatura moderna que atinge, com maior frequência, desfechos trágicos.

Palavras-chave: Saramago; Plauto; duplo; identidade; mito. 
GONÇALVES NETO, Nefatalin. The Order and Chaos: Plautus and Jose Saramago. Dissertação (Mestrado em Literatura Portuguesa). Faculdade de Filosofia Letras e Ciências Humanas. São Paulo: Universidade de São Paulo, 2010.

\begin{abstract}
The theme of the double is recurring issue in the literature since early times, founding it up different forms of constitution of duplicity. This study aims to analyze the works Amphytruo, of the Latin writer Plautus and O Homem Duplicado, of the Portuguese writer Jose Saramago by investigating the theme of this double in the two works in question. Thus, the dialogue between the works is established through the myth of Host, which is taken up by two writers transfigured for the intentions of each. Our purpose is supported by comparative literature to investigate how the theme of the double is treated in each work, to which direction the immanent identity crisis points in each and examine what intertextual mechanisms each writer uses to create his works returning / renewing its prototype. The analysis of these works has as theoretical support, Bakhtin studies on dialogism and the intertextual elements of addition, deletion, inversion and displacement. Through this analysis, we examine how the authors take up the subject of the double to approach the identity split of the subjects of their times. From this study we learn that the classic literature, for being monolithic, does not assumes dramatic dimensions, unlike the modern literature which affects, more often, tragic endings.
\end{abstract}

Keywords: Saramago, Plautus, double, identity, myth. 


\section{ABREVIATURAS UTILIZADAS}

Abreviaturas dos títulos das obras de José Saramago e de Plauto usadas neste trabalho:

A93 - O Ano de 1993

AMRR - O Ano da Morte de Ricardo Reis

$\mathrm{AN}-A$ Noite

ANF - O Anfitrião

$\mathrm{BV}$ - A bagagem do Viajante

CAD - O Caderno

CAD II - O Caderno II

CAM - Caim

CAV - A Caverna

CID - O Conto da Ilha Desconhecida

CL1 - Cadernos de Lanzarote. Vol. I

CL2 - Cadernos de Lanzarote. Vol. II

DG - Don Giovanni ou o dissoluto absolvido

DMO - Deste Mundo e do Outro

EC - Ensaio sobre a Cegueira

EJC - O Evangelho segundo Jesus Cristo

EL - Ensaio sobre a Lucidez

FP - Folhas Politicas

HCL - História do Cerco de Lisboa

HD - O Homem Duplicado

IM - As Intermitências da Morte

JP - A Jangada de Pedra

LC - Levantado do Chão

MC - Memorial do Convento

MFM - A maior Flor do mundo

MPC - Manual de Pintura e Caligrafia

ND - In nomine Dei

OA - Os Apontamentos: Crônicas Políticas

OC - Objecto Quase

ODLT - As Opiniões que o DL Teve 
PA - Provavelmente Alegria

PCS - Poética dos Cinco Sentidos

PM - As pequenas Memórias

$\mathrm{PP}$ - Os Poemas Possíveis

QFL - Que farei com este livro?

SVFA - A segunda vida de Francisco de Assis

TP - Terra do Pecado

TN - Todos os Nomes

$\mathrm{VE}-A$ Viagem do Elefante

VP - Viagem a Portugal 
SUMÁRIO

INTRODUÇÃO 14

1. DO CAOS À ORDEM: A LITERATURA E A QUESTÃo DO DUPLO. 23

1.1 Mo(vi)mentos do duplo. 23

1.2 E no princípio... era o Duplo 32

2. O CAOS DA ORDEM: PlaUto E SUA (RE)LEITURA DO MITO DE ANFITRIÃO 47

2.1 Plauto: o Mito e a Peça 47

2.2 Perspectivas Teóricas 54

2.2.1 Acréscimos 58

2.2.2 Supressões 59

2.2.3 Inversões. 62

2.2.4 Deslocamentos. 66

3. A ORDEM DO CAOS?: SARAMAGO E A LEITURA D'O ANFITRIÁOO PLAUTINO. 75

3.1 Entre a Ordem e o Caos. 75

3.2 Ordenando o Caos. 78 
3.2.1 Acréscimos 83

3.2.2 Supressões. 87

3.2.3 Inversões. 91

3.2.4 Deslocamentos. 94

3.3 As Faces do Caos 105

4. ORDEM/CAOS: ELEMENTOS PARA UM REMATE TÉCNICO DA ARTE VIVIDA (OU DA VIDA ESTETIZADA).

4.1 Identidades Clássicas, Solidez e Harmonia 114

4.2 Identidades Contemporâneas, e Duplicadas. 116

5. CONSIDERAÇÕES FINAIS: AO MODO DE CONCLUSÃo, MAS APENAS O COMEÇO 


\section{INTRODUÇÃO}

É o poeta português Fernando Pessoa quem diz que, em todo bom texto literário, se encontra um fio da obra de Homero, representante maior da tradição literária do Ocidente. Tal afirmação ilustra como certos temas e motivos que tiveram origem na antiguidade clássica percorreram um longo caminho até chegarem à contemporaneidade.

$\mathrm{Na}$ antiguidade greco-latina, a concepção de Homem não é a de "eu subjetivo" (JAEGER, 1995, p. 14), mas, ao contrário, envolve a "consciência gradual das leis gerais que determinam a essência humana" (JAEGER, 1995, p.15). De acordo com os antigos gregos, a constituição da identidade do cidadão, ao invés de passar pelo individualismo, prende-se ao conceito de humanismo. Para eles, existe apenas o "Homem como ideia", considerado "na sua validade universal e normativa". (JAEGER, 1995, p.15). Em síntese, os indivíduos são moldados pela norma da comunidade e, portanto, não existem como pessoas livres, ma como frutos da educação coletiva. As atitudes da personagem Anfitrião, por exemplo, na peça homônima de Plauto, não são livres, mas ditadas, normatizadas pela lei divina, ou seja, pelos desígnios de Júpiter em relação a seu destino.

Já na modernidade a constituição do sujeito passa por uma crise, no sentido de que o real que lhe é previamente dado é posto em xeque, gerando, como consequência, o questionamento do próprio sujeito. Bakhtin é um dos pensadores contemporâneos a enfocar essa questão da identidade tal como ela se espelha no discurso, uma vez que tanto este quanto o ser humano possuem camadas profundas que estão em constante diálogo, indicando que tanto um quanto o outro são abertos e questionáveis. A modernidade, assim, rompe com o normativismo do pensamento clássico greco-latino ao questionar aquilo que é fechado, delimitado, orientado no sentido do Olimpo para o humano.

Essa perspectiva de intercâmbio entre as visões de mundo clássica e contemporânea encontra, entre as atuais correntes da teoria literária, um caminho mais que necessário para se pensar as narrativas de modo geral, tanto as do século XX quanto as produzidas neste começo do século XXI. Esse caminho é o do desdobramento teórico em esforços para chegar a um conceito que permita esclarecer as relações que as obras literárias estabelecem entre si, relações que a crítica decidiu chamar intertextualidade (uma das maiores descobertas no campo de pesquisa literária do século XX).

Essas relações possibilitam ao estudioso penetrar de forma mais profunda tanto nos emaranhados da estrutura literária quanto em sua extensa rede de 
influências/recortes/palimpsestos. Essa exigência de análise advém do fato de que a literatura da contemporaneidade, com seu anseio de rever a situação do sujeito e de seu discurso, termina por criar um veio de releituras do passado, para reconstruí-lo à medida que lhe confere novas luzes. Assim, o reconhecimento das relações intertextuais e de seus efeitos de sentido torna-se, então, um procedimento analítico-operacional passível de florescer apenas na contemporaneidade, já que corresponde ao anseio de reler o antigo e revesti-lo do novo.

O conceito de intertextualidade atrela-se aos métodos e finalidades da Literatura Comparada. Originada na França em meados do século XIX, a Literatura Comparada caracterizou-se como um novo procedimento metodológico na área dos estudos literários, os quais, em razão de uma visão dominante na época, vincularam-se a uma perspectiva historicista de análise, assente no reconhecimento de fontes, influências e paralelismos interpretativos, tais como autor/autor, obra/obra, movimento estético/ movimento estético, entre outros fatores.

A literatura comparada, por meio de seus teóricos, pensava (e ainda pensa) em tornar evidentes os diálogos que as obras estabelecem entre si. Além disso, é importante acrescentar que, à época em que teve início esse tipo de literatura, Goëthe introduzira a expressão Weltliteratur, traduzida como literatura mundial, indicando "o tempo em que todas as literaturas se uniriam numa só." (WELLECK \& WARREN, 1971, p. 60-1). Segundo os próprios autores, o termo traduz "o ideal da unificação de todas as literaturas numa grande síntese, em que cada nação desempenhasse seu papel num concerto universal.” (WELLECK \& WARREN, 1971, p. 61).

Tais perspectivas assumiram junto à disciplina uma postura mais coerente, propondo a avaliação da obra de arte como diálogo intemporal entre textos, por meio de apropriações, reformulações, atualizações e renovações. Além de colocar o objeto estético como foco central de estudo, essas conquistas também conceberam a produção literária como um intercâmbio entre obras literárias diferentes. Para Perrone-Moisés:

estudando relações entre diferentes literaturas nacionais, autores e obras, a
literatura comparada não só admite, mas comprova que a literatura se produz
num constante diálogo de textos, por retomadas, empréstimos e trocas. A
literatura nasce da literatura; cada obra nova é uma continuação, por
consentimento ou contestação, das obras anteriores, dos gêneros e temas
existentes. Escrever é, pois, dialogar com a literatura anterior e com a
contemporânea. (1990, p. 90).

Desta forma, embasados nos conceitos da literatura comparada e em outros que 
forem necessários, o que este estudo procurará realizar é, basicamente, uma atividade de leitura, um exercício de interpretação comparativa entre a narrativa contemporânea portuguesa, representada pelo romance O Homem Duplicado (2002), de José Saramago, e o texto dramatúrgico latino $O$ Anfitrião (1994), de Tito Maccius Plauto. O recorte privilegiado no exame das duas obras será o tratamento dado ao tema do duplo, denominador comum entre ambas.

Essa aproximação se dará por dois caminhos diferentes: o primeiro, pela aproximação intertextual das duas obras, por meio de seus elementos estruturais, o que permitirá um estudo analítico das duas obras; o segundo se dará no sentido de desvendar como as obras em análise propiciam uma reflexão interpretativa da questão da alteridade e da identidade do indivíduo em épocas diferenciadas (no século II a. C., com Plauto, e na contemporaneidade, com Saramago). Essa linha se mostra necessária, já que uma das preocupações do escritor português é a de pensar e avaliar a questão do ser humano e suas problemáticas contemporâneas.

O escritor português José Saramago, único escritor em língua portuguesa a ser galardoado com o Prêmio Nobel de Literatura, é autor de uma gama imensa de escritos, que vão desde o conto, passando pela poesia e a crônica, até chegar aos romances ${ }^{1}$, seu gênero de início (com Terra de Pecado) e, muito provavelmente - levando em conta as opiniões dadas pelo autor em diversas entrevistas -, seu gênero derradeiro. Nesse caminho, além dos diversos procedimentos formais inovadores que Saramago introduz em seus romances, chamam a atenção temas instigantes, problematizadores das questões da contemporaneidade, que acabam por se tornar uma constante na sua obra. Um deles alude ao conflito do homem moderno em relação à sua solidão e à dificuldade na relação com o Outro. Há também o tema da reavaliação da verdade do discurso histórico enquanto meio

\footnotetext{
${ }^{1}$ Os escritos de Saramago incluem três livros de poesia (Os Poemas Possíveis, Provavelmente Alegria e $O$ ano de 1993), três de contos, sendo um em conjunto (Poética dos Cinco Sentidos - O Ouvido, Objecto Quase e $O$ conto da Ilha desconhecida), quatro de crônicas (Opiniões que o DL teve, Os apontamentos e A bagagem do Viajante e Deste Mundo e do Outro), cinco peças de teatro (Que Farei Com Este Livro?, A segunda Vida de Francisco de Assis, In Nomine Dei, Don Giovanni ou o dissoluto absolvido e $A$ Noite), um livro infantil ( $A$ maior Flor do Mundo), um livro de viagem (Viagem a Portugal), cinco diários (Cadernos de Lanzarote: diários I, II, III, IV e V), um livro de crônicas políticas (Folhas Políticas), 17 romances (Terra de Pecado, Manual de Pintura e Caligrafia, Levantado do Chão, Memorial do Convento, O Ano da Morte de Ricardo Reis, História do Cerco de Lisboa, A Jangada de Pedra, O Evangelho segundo Jesus Cristo, Ensaio sobre a Cegueira, A Caverna, Todos os Nomes, O Homem Duplicado, Ensaio Sobre a Lucidez, As Intermitências da Morte, As pequenas memórias, A viagem do Elefante e Caim) e dois livros que reúnem seus textos de internet, presentes no blog José Saramago (O caderno e $O$ Caderno II) até o momento.
} 
de análise e avaliação do real, igualmente reincidente na obra do escritor português. Podemos ainda levantar um terceiro tema importante, que seria o das interações sociais no mundo atual.

Nas linhas e entrelinhas de $O$ Homem Duplicado, por exemplo, podem ser entrevistas essas questões temáticas, desenvolvidas por meio de diversos recursos complexos, como a ironia fina, a inversão, o discurso socrático, o solilóquio e a paródia. Tais elementos que permeiam a narrativa possibilitam a coexistência de diversos gêneros, como o policial, a narrativa fantástica e a narrativa mítica ${ }^{2}$. Essa forma narrativa, que, nesta dissertação, optamos por chamar de romance, possui, em Saramago, uma forma que não pode ser reduzida a rótulos, já que não pode denominar-se romance policial - apesar de seu enredo enigmático e acelerado - porque não possui toda a estrutura do gênero; nem como narrativa fantástica - apesar de seu caráter insólito - pois sua filiação ao gênero é mais motivacional que temática; nem mítica - apesar de recorrer a um topos antigo no gênero -, já que subverte a direção do destino das personagens, como veremos mais adiante.

A questão da duplicidade, topos recorrente dentro da literatura em geral, vem acrescentar à narrativa saramaguiana um elemento artístico a mais, que permite ao escritor construir uma figurativização do homem moderno. Perpassa por essa figurativização a questão da identidade do ser humano contemporâneo: o protagonista da narrativa descobre, ao ver um determinado filme, que o ator que está a representar na tela é seu sósia.

O conflito desencadeado em Tertuliano Máximo Afonso (o protagonista da narrativa) remete, tematicamente, ao mito do duplo, que tem uma de suas raízes no mito grego de Anfitrião. Nesta dissertação, esse mito será trabalhado na obra intitulada $O$ Anfitrião, de Plauto, escritor da antiguidade latina.

Ora, essas premissas temáticas e intertextuais figurativizadas na narrativa saramaguiana nos motivaram a investigar como Plauto operacionaliza o mito grego em seu texto e como Saramago reconstrói a leitura feita por Plauto.

Com este enfoque, procuraremos elucidar algumas pendências que perpassam cada (re)leitura que fazemos do livro de Saramago e que ainda não estão plenamente esclarecidas. Entre elas está a questão do papel exercido pelo tema do duplo nesta obra de

\footnotetext{
${ }^{2} \mathrm{O}$ conceito de gênero é entendido, neste estudo, sob a perspectiva bakhtiniana. Quanto à narrativa fantástica, ela pode ser pensada também sob a perspectiva de Todorov, que, em Introdução à literatura fantástica, concebeu-a como um gênero intervalar entre o estranho e o maravilhoso. Quanto à narrativa mítica, há também que se considerar a visão de André Jolles em Formas simples, que classifica o mito como uma forma simples.
} 
Saramago. Em que medida ele se aproxima ou se diferencia do mito trabalhado por Plauto?

Tais perguntas são passos direcionais que nos estimularam a iniciar esta pesquisa, realizada no sentido de desvendar algumas das relações interpretativas entre esta obra de Saramago e $O$ Anfitrião de Plauto.

Mas, além delas, este romance de Saramago levanta também questões de cunho mais profundo, ligadas aos temas a que nos referimos. Exemplo disso é a que se refere à relação entre a verdade da História e a verdade da ficção, representadas figurativamente por Tertuliano Máximo Afonso - professor de História - e Antônio Claro/Daniel Santa Clara - ator de cinema. Essa relação já estava presente na obra que serve de modelo, Anfitrião, em cujo prefácio aparece um jogo de máscaras em que um deus exerce seu poder e, ao mesmo tempo, é apenas representado por um ator mortal. Outro elo possível de se identificar entre as duas obras é a questão da verdade da história, que, em Plauto, se contrapõe à verdade da religião, sendo Anfitrião o representante figurativo da verdade histórica e Júpiter, da verdade da religião.

Outra nuance que aparece como tema de tratamento artístico é a questão da identidade, tanto do homem clássico, pela pena de Plauto, quanto do homem contemporâneo, desenvolvida pela pena de Saramago.

Em Saramago, esses temas são abordados por meio da paródia, já que, como a própria definição desse gênero revela, sua função é a de rever, de alguma forma, algum conceito cristalizado e inoperante. Por meio da paródia do texto plautino e, por extensão, do mito grego, Saramago busca colocar em questão o conceito de ser humano com identidade estável e definida. Por esse mesmo meio, o autor também pretende rever o conceito de verdade histórica, procurando proceder a uma releitura crítica do passado literário (representado, neste estudo, pela obra de Plauto e pelo modo como este trabalha a questão do mito): em $O$ Homem Duplicado há uma inversão na postura das personagens em relação a conceitos centrais (por exemplo, de verdade, de poder, de institucionalidade etc.).

Enfim, o recurso à paródia possibilita a Saramago realizar em seu texto uma "repetição com distância crítica" (HUTCHEON, 1985, p. 17), ou seja, propor novas posições às personagens. Pelo distanciamento paródico podemos constatar que, com o tempo, o ser humano e, consequentemente, suas verdades, certezas e identidades também mudam.

Sendo o mito de Anfitrião de origem grega e sendo dadas como perdidas as peças 
de Ésquilo (Alcmena), de Sófocles (Anfitrião) e de Eurípedes, que versavam sobre o tema, é Plauto o primeiro escritor a reler literariamente, e do ponto de vista intertextual, o mito de Anfitrião. Saber como essa releitura é feita será o nosso primeiro passo em direção a uma análise mais consistente do que pretendemos nesta dissertação, que é, num primeiro momento, verificar como Saramago relê o mito plautino e com qual intenção ele faz essa leitura.

Para a realização desse percurso, elegemos como instrumentadores de análise e interpretação alguns conceitos que facilitam a via de acesso à inter-relação entre o romance O Homem Duplicado e o texto dramatúrgico O Anfitrião. São eles os conceitos de mito, paródia (segundo as teorias de Bakhtin e Huchteon), intertextualidade e o topos do duplo. A nosso ver, a questão da Identidade é central nos dois textos literários, mas não constitui um conceito operacional, na medida em que aparece como uma questão temática nas duas obras. E para abordar esse tópico, utilizaremos os estudos de Stuart Hall, Bakhtin, entre outros.

Intentamos efetuar o cotejo entre as duas obras enfocadas no trabalho (O Homem Duplicado e $O$ Anfitrião) por meio do levantamento dos elementos estruturais de cada uma delas e da função que desempenham, com destaque para os elementos comuns a ambas, pois, de alguma forma, eles contribuem para respondermos às formulações propostas inicialmente.

Para isso trabalharemos os seguintes elementos: inversão, deslocamento, supressão e acréscimos, todos encontrados na obra Problemas da Poética de Dostoiévski, de Bakhtin. Esses elementos, que podemos definir como relação interdiscursiva de repetição na diferença, instauram o que Bakhtin caracterizou como diálogo textual ou como uma das formas existentes de dialogismo, uma forma relacional entre dois sistemas semióticos, em que o primeiro, ao invés de se apagar em benefício do segundo, se presentifica onde ambos os textos guardam suas respectivas identidades, a despeito da operação de recorte e colagem que caracteriza o processo de leitura/escrita.

No entanto, é necessário saber que as relações provenientes desse processo dialógico entre-textos advêm de dois caminhos: o da tradição de um topos literário milenar e de outro que se direciona para a realidade da contemporaneidade. São caminhos aparentemente diversos e opostos, mas, na verdade, paralelos e complementares. É esse trabalho de assimilação e transformação, mescla entre a tradição e a ruptura, as releituras do caos social imediato e os diálogos entre obras que ora pretendemos explanar, apontando 
os caminhos de interpretação que os livros aqui estudados deixam entrever.

Sem querer cair num discurso demasiado explicativo (tautológico, até), mas apenas desejando esclarecer o pressuposto orientador deste estudo, ressaltamos que todos os pontos até aqui ligeiramente enfocados estão mais longamente desenvolvidos no texto que compõe o corpo da nossa investigação. Este tem como título A Ordem e o Caos: Plauto e José Saramago e se desenvolverá em cinco capítulos, cuja estrutura passaremos a expor.

No primeiro capítulo, intitulado "Do Caos à Ordem: a Literatura e a questão do duplo", abordaremos sucintamente alguns dados acerca do tema do duplo, conceito que servirá para demonstrar como essa forma está inserida vastamente na literatura universal e será base para analisar as duas obras trabalhadas. Para o tratamento do tema do duplo, valemo-nos de leituras específicas de alguns críticos e especialistas no assunto, como Carla Cunha, Nicole Fernandes-Bravo e Sigmund Freud.

No segundo capítulo, intitulado "O Caos da Ordem: Plauto e sua (re)leitura do mito de Anfitrião", apresentamos a análise intertextual entre o texto teatral de Plauto e a narrativa do mito de Anfitrião. Nossa intenção é elencar analiticamente os elementos de acréscimo, inversão, supressão e deslocamento usados pelo escritor latino para elaborar seu texto. Nessa análise, além de proceder ao levantamento dos elementos intertextuais, serão explicitadas as bases teóricas em que Plauto se apoia para escrever sua peça, quais as concepções subjacentes ao seu texto e como ele lida com as transgressões que realiza na retórica que segue.

O terceiro capítulo, “A Ordem do Caos?: Saramago e a leitura d'O Anfitrião plautino", versará sobre o romance de Saramago. Nele examinaremos como o autor, em suas linhas mestras, retoma o texto plautino para com ele dialogar. Para a análise d'O Homem Duplicado, realizaremos novamente o levantamento dos elementos de acréscimo, inversão, supressão e deslocamento, usados, desta vez, pelo escritor português na construção de sua obra. Para elaborar este capítulo, realizaremos estudos e leituras de textos sobre o conceito de intertextualidade, introduzido por Mikhail Bakhtin e retomado por Julia Kristeva.

O quarto capítulo compreende um trabalho simultâneo com as obras, por isso recebeu o título de "Ordem/Caos: elementos para um remate técnico da arte vivida (ou da vida estetizada)". Nele, procederemos à interpretação das duas obras em questão pelo viés da identidade. Nossa base teórica está em Stuart Hall, que nos apresenta questões temáticas encontradas no corpus sob análise. Ainda aqui trataremos da questão da forma de 
vivência da personagem no mundo literário, e que traduz em Plauto uma visão cômica e em Saramago uma visão trágica. Explicitaremos a ideia de que Saramago retoma a tradição representada pela peça de Plauto para (re)pensá-la a luz dos acontecimentos pós-modernos e dar-lhe novos significados, conforme a necessidade da época atual. Para tanto, trabalharemos com os conceitos de pós-modernismo explicitados por Linda Hutcheon, questionando e procurando possíveis respostas para compreender a narrativa que analisamos. Por fim, trataremos também de algumas questões de cunho mais teórico, como o uso da paródia e os conceitos de literatura e história inseridos, a partir da relação ficcional/real, na obra de Saramago. Precisamos esclarecer que o elemento histórico está ausente na obra de Plauto, havendo, neste caso, um sucedâneo na figura do poder divino.

Finalmente, apresentamos as Considerações Finais, em que tentamos juntar todos os fios urdidos ao longo do trabalho. Na finalização, ao invés de apresentarmos dados conclusivos, apontaremos os pontos mais conflituosos e obscuros das obras analisadas, pois entendemos que um trabalho como este não tem e nunca terá a possibilidade de esgotar as diversas e possíveis aberturas ${ }^{3}$ que as obras têm em relação a seus leitores. Fiéis ao pressuposto teórico com o qual comungamos, nosso epílogo também é aberto; por isso pontuamos também algumas situações teórico-interpretativas que poderiam ter sido tratadas e não o foram. Desse modo, juntamos aos fios anteriores outros fios, de modo a possibilitar novas investidas, já que a própria obra de arte literária é um emaranhado que permite sempre novas investigações por parte do analista que deseja adentrar nessa ordem caótica e inquietante que é a literatura e seu mundo.

Por fim, julgamos necessário explicar que o titulo de cada capítulo foi escolhido a partir da epígrafe do livro saramaguiano "O caos é uma ordem por descobrir". Afinal, o exercício que ora realizamos nada mais é do que uma ordenação critica do caos (e por isso infinitamente criativo) que são os livros de Plauto e Saramago.

Nosso intuito com relação a este campo de desenvolvimento de trabalho é tentar desvendar ao máximo a pluralidade de conteúdos que cada obra possui, examinando ainda a síntese que os autores promovem. E já que as características do texto plautino apontam, enquanto o texto saramaguiano abarca a polifonia, o dialogismo e a dialética, nosso texto,

\footnotetext{
${ }^{3}$ Aqui, ao mencionarmos a abertura da obra, nos referimos ao posicionamento de Umberto Eco em seu livro Obra Aberta, no qual o autor lança a ideia de que toda obra tem suas possibilidades de interpretação e que estas vão sendo conquistadas pelos leitores por meio de seu relacionamento e aproximações com a leitura em geral.
} 
numa busca de diálogo interpretativo com os textos estudados, acaba por assimilar essas mesmas características, tentando refletir o texto dos dois escritores que ora tentamos fazer se encontrar nestas frágeis linhas. 


\title{
CAPÍTULO I \\ DO CAOS À ORDEM: A LITERATURA E A QUESTÃO DO DUPLO
}

\begin{abstract}
(...) o que acontece e toda gente sabe que isto é assim (se calhar vou ter que voltar ao Fernando Pessoa) é que nós não somos uma unidade, somos uma pluralidade, levamos a vida a disciplinar ou a controlar essa palpitação de figuras que levamos dentro, tentamos apresentar-nos ao mundo e aos outros como unos e inteiros: às vezes consegue-se com maus resultados, que podem levar ao suicídio ou à loucura.
\end{abstract}

José Saramago

\subsection{Mo(vi)mentos do Duplo}

A origem do tema do duplo na literatura é o primeiro aspecto que devemos sondar para localizarmos as relações entre o mito de Anfitrião e as obras que enfocaremos nesta pesquisa, O Anfitrião, texto dramático de Plauto, e $O$ Homem Duplicado, romance de José Saramago. O caminho para isso se mostra deveras tortuoso porque essa temática nasce no interior de várias lendas mitológicas e até religiosas para, só mais tarde, se deslocar para a literatura propriamente dita e aí se firmar. O estudo desse aspecto implica, então, buscar e perscrutar um dos nascedouros do tema para, por fim, delimitar o ponto de encontro entre o que ele era originalmente e sua transformação pela literatura, pois tal vertente constituirá, de fato, um instrumento fundamental para a análise proposta neste trabalho.

No desenvolvimento do tema do duplo na literatura e no estudo das diferentes formas de representação ao longo do seu percurso histórico, identificamos suas profundas raízes míticas e mitológicas, que se expandem até o romance contemporâneo, e reconhecemos tanto a recorrência do tema nas diversas épocas quanto o fato de que a noção da duplicidade do ser altera-se conforme o contexto social e o gênero no qual se insere. Segundo Juan-Eduardo Cirlot, a ideia de duplicação diz respeito ao sistema binário, "à dualidade, à contraposição e ao equilíbrio ativo de forças" (1984, p. 217). O mito do duplo está presente há muito tempo em nossa civilização, o que nos leva a supor que é um dos mais antigos de que temos notícia. Incessantemente moldado e remoldado pela literatura e por outras artes, cada época lhe confere feição conforme sua própria imagem.

Assim, o passando por transformações ao longo dos séculos, o mito do duplo atravessa gêneros literários, hermenêuticas e insere-se nas diversas culturas, valendo-se da sobreposição de imagens, em um mosaico sempre mutante de motivos, com diversas variações. Jogo de espelhos e laboratório em que se operam transformações, ele atrai e anuncia obras e fatos do cotidiano. 
Enfim, é muito antiga a origem do tema, daí seu nascimento poder ser tomado como um mito fundador. Difícil é prescrever sua origem e, por mais que procuremos, sempre nos perdemos em seus interstícios. Entretanto, mesmo sem uma data pré-fixada, nosso olhar científico inclina-se a identificar seu nascedouro na narrativa intitulada Gilgamesh.

A epopeia de Gilgamesh, uma das mais importantes da literatura acádicosumeriana, é, provavelmente, o documento mais antigo em que surge a questão do duplo. Apesar de talvez terem existido, além e antes dela, outras narrativas e lendas que se utilizaram do duplo, nenhuma delas chegou até nós e isso nos leva a concebera epopeia acádica como a narrativa mais antiga de que se tem notícia a utilizar o motivo do duplo em sua trama.

O aparecimento de Gilgamesh deu-se no mundo moderno ocidental em 1872, por meio de um achado arqueológico de doze tabuinhas, que possuem aproximadamente três mil linhas, das quais apenas duas mil foram decifradas.

Esse relato babilônico versa sobre a história de Gilgamesh, uma figura histórica que "viveu provavelmente por volta de 2600 a.C. Ele consta nos registros como o quinto rei de Uruk, no sul da Mesopotâmia, e depois se tornou um herói folclórico" (ARMSTRONG, 2005, p. 64). A versão final da história desse rei foi escrita por volta de 1300 a. C.

No poema, vemos que Gilgamesh é um homem sem rumo, que possui uma tempestade em seu peito. Ele aterroriza seu povo, que pede ajuda aos deuses para se livrar desse mal. Como os deuses não estão mais dispostos a intervir nos assuntos humanos característica dos mitos que surgem nessa época de urbanização das sociedades ${ }^{4}$ - enviam à terra um adversário para Gilgamesh, Enkidu, o raio de $\mathrm{Anu}^{5}$, um homem que vive de forma selvagem e primitiva nos campos.

A domesticação de Enkidu ocorre por meio de sua relação com a prostituta Shamhat, enviada a ele por Gilgamesh, que descobre sua existência por meio do povo. Os dois, Gilgamesh e Enkidu, se tornam amigos e saem pelo mundo em busca de aventuras. Em umas delas, encontram o ser mitológico Humbaba, que era inimigo da deusa Shamhat.

\footnotetext{
${ }^{4} \mathrm{O}$ surgimento da epopeia se dá exatamente no momento em que a sociedade passa de um processo rural para um processo urbano. Segundo Armstrong (2005, p. 53), é no período entre 4000 e 800 a. C. que os seres humanos passam a construir cidades e depois estradas, "primeiro na Mesopotâmia e no Egito, depois na China, na Índia e em Creta" (Ibidem). Esta informação é importante para compreendermos a função do duplo, da qual trataremos posteriormente.

5 "O raio de Anu", juntamente com "O verbo de Anu/Ninurta" e "O machado", são os epítetos de Enkidu na epopeia, assim como "Aquele que sabia tudo" é epíteto de Gilgamesh.
} 
Eles invocam a proteção da deusa Ishtar e enfrentam a criatura, vencendo-a no final. É principalmente nesse trecho que apreendemos a aplicabilidade das considerações de Armstrong sobre a indisposição dos deuses em intervir nos assuntos humanos e a negação dos deuses por parte dos homens. De fato, nese trecho vemos seres humanos lutandocontra deuses e vencendo-os. m-. Vemos uma invocação ajuda divina e não há nenhuma intervenção por parte dos céus. E, por fim, temos uma criatura divina aparece para lutar com humanos, mas é derrotada. Todos esses detalhes nos levam a reconhecer como verdadeira a afirmação de Armstrong, já que são agora os homens, e não mais os deuses, que dominam a terra e tudo que nela habita.

Após a batalha com Humbaba, a deusa Ishtar aparece a Gilgamesh e tenta seduzilo. Entretanto, Gilgamesh a despreza por saber que nenhum dos relacionamentos dela havia durado. Furiosa com a recusa, Ishtar pede a seu pai Anu que envie o Touro Celeste para destruir Gilgamesh. O deus atende ao pedido da filha. Entretanto, Gilgamesh e seu amigo destroem a criatura celeste, tal qual haviam feito com Humbaba.

No início da sétima tabuinha, Enkidu sonha, a mãe de Gilgamesh interpreta seu sonho e Enkidu fica sabendo que um conselho de deuses tinha decidido matá-lo. Enkidu, então, adoece e morre. Gilgamesh se revolta e constrói uma estátua de lápis-lázuli para o amigo. Após chorar copiosamente a sua morte, o herói, para encontrar um modo de ressuscitar o amigo morto, resolve procurar Utnapishtim, o único sobrevivente de um dilúvio e único também a conquistar a vida eterna.

Gilgamesh atravessa o mundo em busca de Utnapishtim e, ao encontrá-lo, este lhe conta sua história. Mesmo sem conseguir a imortalidade, o novo amigo de Gilgamesh revela-lhe o segredo da eterna juventude, uma erva no fundo do mar. O herói encontra a erva, mas uma serpente sente o cheiro dela e a rouba. A última tabuinha - XII - narra o retorno do herói a Uruk, sem conseguir a eternidade, mas aclamado e reconhecido pelo povo por suas grandes façanhas.

Esta é uma síntese da epopeia de Gilgamesh, e podemos ver, logo no início, que ela aborda, em suas linhas e entrelinhas, alguns aspectos relativos ao duplo. Há trechos em que eles são linguisticamente marcados - por exemplo, quando o narrador revela que Enkidu é um duplo de Gilgamesh: "Um só não pode/são estranhos/é perigoso o caminho e um não/pode, mas dois/dois.../uma corda tripla não se rompe facilmente/um leão valente não é capaz de vencer dois/de seus filhotes." (GILGAMESH, 1998, p. 54-55). A duplicidade 
também pode ser encontrada no fato de que as duas personagens da narrativa religiosa são filhos da mesma mãe, Aruru (ou Anu) ${ }^{6}$.

Apesar de ser talhado para combater Gilgamesh, Enkidu acaba por tornar-se o parceiro do herói, já que os dois, ao invés de duelarem um contra o outro, duelam em parceria contra Humbaba e o Touro Celeste.

Um é rei, homem, forte e urbanizado; o outro é animal, serviçal, de grande percepção e rural. Os dois são como que complementares um do outro, ou seja, duplos. O mesmo sangue, mas com origens e qualificações diferentes.

Importa notar que essa narrativa mitológica influenciará outras narrativas religiosas, dentre elas a Bíblia, que se baseia no relato que Utnapishtim conta a Gilgamesh para compor a história do dilúvio que Noé enfrenta. Não é apenas a epopeia de Gilgamesh que dialoga com o texto bíblico. O Antigo Testamento inteiro está repleto de narrativas nas quais a temática do duplo está presente. E exemplo disso é o relato da criação do mundo, em que se introduz uma série de duplicidades que virão a constituir motivos recorrentes na literatura; primeiro, a luz opondo-se às trevas do caos primordial; depois, o dia e a noite; o céu e os mares; e, enfim, o homem e a mulher, a quem coube o domínio de todos os seres criados (Cf. GÊNESIS 1, 1-26 In: A Bíblia de Jerusalém, 1991, p. 31-32).

Outros exemplos bíblicos em que a temática do duplo pode ser encontrada são as histórias de Caim e Abel e de Esaú e Jacó. A história de Caim e Abel versa sobre dois irmãos que em tudo se parecem e que vivem juntos. Certo dia, para agradar a Deus, ambos resolvem oferecer-Lhe um sacrifício. Caim, sendo um lavrador, Lhe oferta, em oblação, frutos da terra. Já Abel oferece a gordura queimada dos seus primogênitos. "O Senhor olhou com agrado para Abel e para sua oblação, mas não olhou para Caim e para os seus dons." (Cf. GÊNESIS 4, 4-5a, in A Bíblia de Jerusalém, 1991, p. 35). Por sentir ciúmes de seu irmão e do bom grado com que o Senhor olhou para a oblação dele, Caim acabou matando Abel e foi punido por Deus.

A história de Esaú e Jacó é outra narrativa em que a inveja e o ciúme são motivos de discórdia. Como Caim e Abel, Esaú e Jacó também são irmãos, sendo Esaú privilegiado com uma bênção especial por ser o primogênito. Certo dia, ao chegar exausto de uma caçada [Esaú era caçador, e Jacó "homem tranquilo, que morava na tenda." (A Bíblia de

\footnotetext{
6 "Vós, Aruru, que também criastes Gilgamesh,/Agora criai alguém para ele, com igual impetuosidade no coração!/Deixai que duelem, e deixai Uruk serenar!"/Ao ouvir isso concebeu em si o verbo de Anu [Enkidu]./Aruru lavou as mãos, amassou um punhado de barro e atirou-o à terra./Enkidu por Aruru foi criado, Enkidu (o homem primitivo)/o guerreiro, rebento do silêncio, o raio de Ninurta. (GILGAMESH, 1998, p. 23).
} 
Jerusalém, p. 69).], Esaú, morto de fome, troca com o irmão Jacó seu direito de primogenitura por um prato de guisado. Com o passar dos anos, o pai dos dois chega ao fim de seus dias e, já cansado e sem enxergar nada, pede ao mais velho, Esaú, que vá caçar e, com o que conseguisse na caça, lhe preparasse um guisado. O pai promete a Esaú que, logo depois de comer seu guisado, iria dar-lhe a bênção da primogenitura. Ao saber disso, Jacó corre, pega um dos animais do rebanho do pai, mata-o e prepara um ensopado. Depois se veste com as roupas de Esaú e rouba-lhe a bênção. Após esse roubo, com medo de ser morto pelo irmão, Jacó foge durante anos, até se reencontrar e ser perdoado pelo irmão.

$\mathrm{Na}$ Bíblia, além das histórias de Caim e Abel e de Esaú e Jacó, há ainda muitas outras que tratam da temática do duplo, mas apenas a menção a essas duas já é suficiente para o que nos interessa.

Relações diádicas no relato da origem do universo criado também podem ser encontradas em diversas culturas. Entre os hindus, uma das versões cosmogônicas atribui a criação do ser feminino à solidão do Uno, o Brahma anterior a todas as coisas, formado a partir do aquecimento do Nada Primordial. Do abraço desses dois seres teriam surgido todos os outros seres do mundo. (Cf. UPANISHAD, I, 4, 1ss)

Além de estar presente em mitos cosmogônicos, a duplicidade se manifesta em outras modalidades de relatos das mais diversas civilizações, inclusive as nórdicas e germânicas, nas quais o duplo é presságio de morte (cf. RANK, 1939, p. 104-106). Em outros textos, a duplicidade tenta explicar a existência da sombra, da alma e até da reencarnação, como é o caso das divindades femininas/masculinas do Egito, na forma de sua manifestação vital, o deus Ka.

O duplo também está presente n'O Banquete, de Platão, obra que faz referência ao mito do andrógino. Nesta obra, "o homem desdobrado, a mulher desdobrada ou o andrógino representavam a união primitiva, o estado de perfeição a que os homens põem fim quando ameaçam os deuses: a bipartição é o castigo infligido pelos deuses" (BRAVO, 1997, p. 262).

Segundo a leitura completa do mito do andrógino, tal qual é relatada n'O Banquete, havia, na origem da humanidade, três seres: Andros, Gynos e Androgynos, sendo Andros a entidade masculina, composta de oito membros e duas cabeças, ambas masculinas; Gynos, a entidade feminina, mas com características semelhantes às de Andros; e Androgynos, composto por uma metade masculina e outra feminina. Por serem muito poderosos, os deuses resolveram separá-los: a partir de Andros, originaram-se dois homens, que, apesar 
de terem seus corpos agora separados, tinham suas almas ligadas, por isso ainda eram atraídos um pelo outro. $\mathrm{O}$ mesmo ocorre com os pares formados a partir de Gynos. Andros deu origem aos homossexuais, Gynos, às lésbicas e Androgynos, aos heterossexuais.

Segundo Aristófanes, personagem d'O Banquete, os humanos seriam, então, divididos em um terço de heterossexuais, e dois terços de homossexuais. De acordo, portanto, com o mito platônico, a corriqueira expressão "buscar a alma gêmea" aplica-se tanto aos homens duplos, quanto às mulheres duplas e ao homem e à mulher, originariamente unificados. Falando da gênese da natureza humana, o filósofo grego afirma, na voz do comediógrafo Aristófanes:

Havia, a princípio, três espécies de homens e não duas, como atualmente: macho e fêmea. O terceiro gênero era formado dos dois primeiros. Extinta a espécie, só o nome lhe sobreviveu. Chamavam-se Andróginos, porque pelo aspecto e pelo nome lembravam o macho e a fêmea (PLATÃO, s.d., p. 39).

Esses seres não são filhos do Sol, como os homens, tampouco da Terra, como o são as mulheres, mas filhos da Lua, que participa da natureza de ambos.

A razão de serem então os sexos em número de três e assim formados é que o masculino era primitivamente um rebento do Sol; o feminino, um da Terra e o comum-de-dois, um da Lua, porquanto também a Lua é comum-de-dois (...). Eram, por conseguinte, dotados duma força e duma robustez formidáveis, inflados dum orgulho imenso; atreveram-se contra os deuses e também a eles se aplica o que diz Homero de Efialtes e Oto, o terem empreendido a escalada do céu para medir-se com os deuses (PLATÃO, s.d., p. 59).

Ao contrário do que ocorre nos contos de fada típicos ou nas narrativas mais comuns, os andróginos não foram felizes para sempre, uma vez que, escalando o Olimpo para fazerem guerra aos deuses, receberam um castigo eterno. A insolente ambição de enfrentar os deuses - da mesma ordem das transgressões de Prometeu (o inventor do fogo) -, foi hábil e exemplarmente punida por Zeus:

Acho que descobri um jeito de existir a Humanidade, mas deixar de insubordinações: enfraquecê-la. Por ora - disse - vou cortar cada um deles em dois (...). Dito isso, fendeu os homens em dois (...). Ora, fendido o físico em dois, cada metade sentia saudade da outra e juntavam-se (...) (PLATÂO, s.d, p. $60)$.

O cruel castigo é uma amarga e irreversível separação dos corpos. As mulheres que provêm da separação das Gynos inclinam-se para outras mulheres, ao passo que os homens originários dos Androstros anseiam pela sua outra metade masculina.

Nesse mito, a duplicação representa a punição dada pelos deuses ao homem e à mulher por ousarem desafiá-los ou desejarem ser semelhantes a eles. A mesma leitura pode ser encontrada na narrativa bíblica da criação, quando Eva prova do fruto que lhe traria 
conhecimento sobre o bem e o mal e a respeito do qual a serpente assegurara que permitiria a Eva ser como Deus. A partir do momento em que come a fruta, tanto o homem quanto a mulher perdem a sua perfeita unidade e são enfraquecidos, sendo fadados a buscar o seu par, com quem voltarão a constituir uma unidade perdida ${ }^{7}$.

Em muitos dos mitos gregos, o traço andrógino pulsa fortemente, como, por exemplo, em Dioniso, que, sendo um dos mais antigos do Panteão, é, muitas vezes, representado de forma andrógina; também é andrógino o vidente da Odisseia, Tirésias, que se tornou cego, segundo o mito, por ter visto duas serpentes sagradas copularem. Segundo Mucci (www.fcsh.unl.pt/edtl/ahtm, 2009), “a serpente é dos mais antigos símbolos e, na forma de Ouroboros, representado na alquimia, é circular, como o andrógino". Outras divindades míticas gregas, como Proteu e Juno, exibem também uma forma andrógina, como representação da fecundidade ou da juventude eterna.

Proteu, filho dos Titãs Tétis e Oceanus, tinha o dom da premonição e, assim, atraía o interesse de muitos que queriam saber as artimanhas do destino. Porém, não gostando de contar os acontecimentos vindouros, ele assumia aparências monstruosas quando algum humano se aproximava. Se esse indivíduo que o procurava fosse corajoso o bastante para encará-lo, então Proteu revelava o que sabia sobre o futuro do procurante. Já Juno, ou Juno Lucina, também conhecida, na mitologia grega, como Hera e Argeia, é a esposa de Júpiter e rainha dos deuses. Sua representação se dá por uma face tapada por duas máscaras, o que sugere sua ambiguidade e duplicidade - artimanha da qual muitas vezes se utilizou para sondar as traições do marido ${ }^{8}$.

$\mathrm{Na}$ evolução do tratamento dado ao tema do duplo, podemos notar que as narrativas míticas apontam para uma divisão, uma separação, e, simultaneamente, para uma união, uma inteireza dos seres. Por exemplo, Gilgamesh e Enkidu, apesar de diferentes, se completam; os andróginos, seja originalmente, seja depois de divididos, também se complementam; no mito indiano e no mito cristão, o homem e a mulher buscam preencher o vazio que existe em suas almas por meio do outro. Em síntese, o duplo, aqui, se faz

\footnotetext{
${ }^{7}$ Essa leitura é confirmada pelas palavras de Jesus no Evangelho de Marcos. Quando questionado pelos fariseus se era correto ao homem divorciar-se de suas esposas, Jesus responde "No entanto, desde o começo da criação, Deus os fez homem e mulher. Por isso, o homem deixará seu pai e sua mãe e os dois serão uma só carne. Assim, já não são dois, mas uma só carne”. (Evangelho de Marcos, 10, 7-9)

${ }^{8}$ Para o conhecimento das ações de cada personagem mítica, recorremos ao Dicionário Mítico-Etimológico de Junito de Souza Brandão. Para referência completa, cf. Bibliografia.
} 
presente pela união de dois contrários (como Gilgamesh e Enkidu) ou de dois iguais (como dois homens ou duas mulheres).

Mircea Eliade, em seu livro Mefistófeles e o andrógino (1991, p. 122 e ss.), faz uma síntese da história e da natureza do mito do andrógino, acentuando que ele implica, "com maior ou menor clareza, a coincidentia oppositorum, reunião dos contrários, a totalização dos fragmentos." (p. 127). Para Eliade, que toma o termo emprestado de Nietzsche, a coincidentia oppositorum exprime o desejo de recuperar a unidade perdida, que obrigara o homem a conceber os opostos como aspectos complementares de uma realidade única.

$\mathrm{O}$ fato de esses temas e esses motivos arcaicos sobreviverem ainda no folclore e surgirem continuamente nos mundos onírico e imaginário prova que o mistério da totalidade faz parte integrante do drama humano. (ELIADE, 1991, p. 128)

Outro escritor a se dedicar ao tema do duplo foi o filósofo alemão Friedrich Nietzsche, que traz, como figuras axiais de $A$ origem da tragédia, duas divindades gregas que carregam em si características que expressam, antipodamente, um "duplo impulso da natureza" (NIETZSCHE, 1992, p. 48) ${ }^{\mathbf{9}}$, as quais, ainda que distantes, em certo momento da história se uniram e formaram o que hoje conhecemos como tragédia. Esses deuses, Apolo e Dionísio, expressam esses impulsos, que o filósofo alemão denomina, respectivamente, de "apolíneo" e "dionisíaco". Ambos são termos de uma oposição central, mas se complementam. São conceitos antitéticos, mas de uma espécie dialética necessária à existência da arte e, além dela, de todos os homens. Nas palavras de Nietzsche:

O contínuo desenvolvimento da arte está ligado à duplicidade do apolíneo e do dionisíaco, da mesma maneira como a procriação depende da dualidade dos sexos, em que a luta é incessante e onde intervêm periódicas reconciliações. Tomamos essas denominações dos gregos, que tornam perceptíveis à mente perspicaz os profundos ensinamentos secretos de sua visão de arte, não, a bem dizer, por meio de conceitos, mas nas figuras penetrantemente claras do seu mundo dos deuses. (NIETZSCHE, 1992, p. 27)

Ao justapor apolíneo e dionisíaco, Nietzsche cria duas forças opostas que funcionam, de certa forma e feitas as devidas restrições, à semelhança da oposição Yin/Yang. Ao apolíneo corresponde o princípio Yang, sobretudo nas suas qualidades de celeste, penetrante, quente e luminoso; e ao dionisíaco, o princípio Yin, como absorvente,

\footnotetext{
9 Apesar de consultarmos mais de uma tradução do texto de Nietzche para compararmos e termos uma melhor contextualização do conteúdo por ele explicitado, usaremos aqui a tradução de Jacó Guinsburg, da Companhia das Letras, que acreditamos ser a mais fiel e atual versão do texto do filósofo alemão. Para referência completa, ver abibliografia, ao final do trabalho..
} 
frio e obscuro ${ }^{10}$. No pensamento oriental, os dois princípios, antipódicos e ao mesmo tempo complementares, abrangem todos os aspectos e fenômenos da vida social, tal como acontece no pensamento helênico. Como esclarece o próprio Nietzsche,

Ambos os impulsos, tão diversos, caminham lado a lado, na maioria das vezes em discórdia aberta e incitando-se mutuamente a produções sempre novas, para perpetuar nelas a luta daquela contraposição sobre a qual a palavra comum "arte" lançava apenas aparentemente a ponte (...) (1992, p. 27).

Edificados nessa justaposição, apolíneo e dionisíaco representam as duas faces do duplo, que, tal como a face de Jano, se contrapõem, mas um não existe sem o seu oposto. “Apolo não podia viver sem Dionísio! O ‘titânico' e o ‘bárbaro' eram, no fim de contas, precisamente uma necessidade tal como o apolíneo!" (NIETZSCHE, 1992, p. 41). Expressa essa dualidade, constatamos que os impulsos analisados por Nietzsche correspondem, em certos aspectos, aos fundamentos do duplo, já que o apolíneo, com sua clareza e seu poder criativo para produzir imagens, aproxima-se da categoria do eu, e Dionísio, com sua obscuridade e embriaguez, do outro, que, no contexto do duplo, representa o elemento duplicado.

Deus dúplice, que une duas facetas em uma só pessoa, Dionísio, como ele mesmo proclama, é, ao mesmo tempo, "o mais terrível e o mais doce"" ${ }^{11}$. Sua essência é igual à do outro. Tanto é assim que vale a afirmação de Vernant:

ele atua para fazer surgirem, desde esta vida e neste mundo, em torno de nós e em nós, as múltiplas figuras do Outro. Ele nos abre, nesta terra e no próprio âmbito da cidade, o caminho de uma evasão para uma desconcertante estranheza. Dioniso nos ensina ou nos obriga a tornar-nos o contrário daquilo que somos comumente. (2006, p. 80)

Nada mais claro que as palavras do helenista para justificar a aproximação que aqui realizamos entre Dionísio e o Outro. Se Apolo é a imagem divina do que Nietzsche chama, retomando as palavras de Schopenhauer, principium individuationis, o ímpeto dionisíaco corresponde à violação desse princípio de individuação, provocando o terror e o êxtase (mesmo sentimento que o duplo causa quando entra em contato com o sujeito a quem duplica).

Ainda segundo Vernant,

Dioniso encarna, segundo a bela frase de Louis Gernet, a figura do Outro. Seu papel não é confirmar e reforçar, sacralizando-a, a ordem humana e social. Dioniso questiona essa ordem; ele a faz despedaçar-se ao revelar, por sua

10 Dionísio representa aquele que apaga toda a mancha de pecado. Já Apolo representa o que liberta a alma do corpo, uma vez que, segundo a filosofia grega, todo corpo é um túmulo.

${ }^{11}$ Citado de As Bacantes, de Eurípedes. 
presença, outro aspecto do sagrado, já não regular, estável e definido, mas estranho, inapreensível e desconcertante. Único deus grego dotado de um poder de maya, de magia, ele está além de todas as formas, escapa a todas as definições, reveste todos os aspectos sem se deixar encerrar em nenhum. À maneira de um ilusionista, joga com as aparências, embaralha as fronteiras entre o fantástico e o real. Ubiquitário, nunca está ali onde está, sempre presente ao mesmo tempo aqui, alhures e em lugar algum. Assim que ele aparece, as categorias distintas, as oposições nítidas, que dão coerência e racionalidade ao mundo, esfumam-se, fundem-se e passam de umas para outras: o masculino e o feminino, aos quais ele se aparenta simultaneamente; o céu e a terra, que ele une inserindo, quando surge, o sobrenatural em plena natureza, bem no meio dos homens; nele e por ele, o jovem e o velho, o selvagem e o civilizado, o distante e o próximo, o além e este mundo se encontram. E mais: ele elimina a distância que separa os deuses dos homens, e estes dos animais. (VERNANT, 2006, p. 77-78)

Apesar de extensa, a citação de Vernant confirma nossa afirmativa sobre a relação direta que há entre a figuração de Dionísio e a do outro. Essa aproximação entre as duas instâncias nos convida a relacionar a figura de Apolo ao Eu. Assim, temos as figurações do apolíneo e do dionisíaco como uma espécie de justaposição dialética, expressão de elementos representativos da duplicidade, fato que permite que as duas figurações expressem uma visão de sujeito clivado, um ser dividido entre duas situações diferentes.

\subsection{E no princípio... Era o Duplo}

No que tange à Literatura, o tema do duplo passa a ser recorrente e alcança seu apogeu a partir do século XVIII, no período romântico, quando têm origem as narrativas cunhadas como "fantásticas". Na verdade, seu introdutor foi Jean Paul Richter no romance Siebenkäs, em que, pela primeira vez, aparece a figura do doppelgänger "e que se traduz por duplo, segundo eu. Significa literalmente 'aquele que caminha ao lado', 'companheiro de estrada'.” (BRUNEL, 2000, p. 261). Já segundo Kiefer, o significado de doppelgänger na Alemanha é "o duplo de antiga tradição, o inconcebível e abominável Outro-igual-aoMesmo.” (KIEFER, 1995, p. 35).

Segundo Bravo (In: BRUNEL, 2000, p.261), o termo "duplo" foi primeiramente tratado sob o nome de "alterego" (ou "outro eu"). Ressaltamos que, tanto em um caso como no outro alter ego e Doppelgänger), temos presente a ideia de um eu vivendo, de maneira conflituosa ou não, com o outro. Neste contexto sócio-histórico, o termo alemão definia uma espécie de alma gêmea ou mesmo um fantasma que persegue um indivíduo, confundindo-se com a sua própria personalidade. 
Nas obras do movimento romântico em que aparecia o doppelgänger, ele nunca era visto por ninguém a não ser pelo seu portador. Não se vê ao espelho, não se mostra a mais ninguém além da perturbadora autoconsciência do ser em duplicação. A grande maioria da literatura de terror e de horror faz uso do duplo por ele ser de forte impacto psicológico, não como um morto-vivo, mas como um ser que vive para atormentar o protagonista ou para ajudá-lo a vencer seus medos e terrores.

Pelo já visto, percebemos que o duplo remonta a épocas bem recuadas no tempo e suas formas de construção variam, assim como a sua forma de utilização, conforme o efeito de sentido a ser transmitido.

Carla Cunha (http://www2.fcsh.unl.pt/edtl/verbetes/D/duplo.htm. 2009), estudiosa do tema, diz que o duplo é algo que,

[...] tendo sido originário a partir de um indivíduo, adquire qualidade de projecção e posteriormente se vem a consubstanciar numa entidade autônoma que sobrevive ao sujeito no qual fundamentou a sua gênese [...]. Nesta perspectiva, o Duplo é uma entidade que duplica o "eu", destacando-se dele e autonomizando-se a partir desse desdobramento. [...]. Podem ocorrer duas modalidades: a) o Duplo apresenta, segundo o julgamento do "eu", características positivas, [ou] características negativas, resultantes de um processo de oposição entre o "eu" e o seu Duplo.

Assim, o duplo é uma composição em que aparecem um mesmo e um outro simultaneamente, por meio do processo de duplicação ou de divisão do $\mathrm{Eu}$, e, "da sua génese, se procura obviar a finitude do ser" (CUNHA, in http://www2.fcsh.unl.pt/edtl/verbetes/D/duplo.htm.2009). O conceito mais comum de duplo é de que ele é algo que, originando-se a partir de um indivíduo, "adquire qualidade de projecção e posteriormente se vem a consubstanciar numa entidade autónoma que sobrevive ao sujeito no qual fundamentou a sua génese, partilhando com ele uma certa identificação". (CUNHA, in http://www2.fcsh.unl.pt/edtl/verbetes/D/duplo.htm, 2009) Julgamos relevante destacar que o duplo é uma entidade duplicadora do $\mathrm{Eu}$, mas uma entidade que se autonomiza a partir de seu desdobramento, por meio da divisão ou da multiplicação.

Cunha afirma que existem duas modalidades do duplo: o endógeno e o exógeno. $\mathrm{O}$ duplo endógeno representa uma extensão do sujeito e seu perfeito desdobramento,

partilha com este traços evidentes que exaltam esse seu estatuto de "sombra". Estabelece-se entre ambos uma relação de harmonia e cumplicidade. $\mathrm{O}$ inverso também é possível, se o duplo gerado a partir de um sujeito permanece enquanto seu contraste, confirmando-se uma relação bilateral de adversidade e oposição. Em ambos os casos, parece notória a noção de que o duplo, tendo tido a sua génese em um sujeito determinado, sendo uma cópia do mesmo, uma mimese, não pode desfrutar do mesmo estatuto ontológico subjacente ao "eu" a partir do 
$\begin{array}{lccc}\text { qual } & \text { se } & \text { originou } & \text { (CUNHA } \\ \text { http://www2.fcsh.unl.pt/edtl/verbetes/D/duplo.htm, 2009) }\end{array}$

O duplo endógeno, portanto, revela que a sua coexistência com o eu nem sempre é pacífica, sendo marcada, muitas vezes, por um desfecho trágico ou de morte. Um exemplo de texto que se utiliza da temática do duplo endógeno é a novela $O$ retrato de Dorian Gray, do escritor Oscar Wilde. Nesta obra, a personagem é jovem em sua vida social diária e simultaneamente envelhecido no interior de seu retrato.

O duplo exógeno, por sua vez, se configura como uma entidade que se formou extrinsecamente a esse "eu". O Duplo pode ser mais do que uma parte integrante
do "eu" e pode originar-se diferentemente, sem que tenha de surgir
necessariamente da sua interioridade. É possível alguém vir a reconhecer em
outrem o seu Duplo. Esse reconhecimento em que dois "eu(s)" se entendem
análogos e partilhando uma identificação anímica, estabelece igualmente o
aparecimento do Duplo (duplo exógeno), desta vez, aplicado a cada um deles
(CUNHA in http://www2.fcsh.unl.pt/edtl/verbetes/D/duplo.htm,
2009).

A nosso ver, A confissão de Lúcio, de Mário de Sá-Carneiro, constitui um bom exemplo da existência de duplos exógenos. Lúcio e Ricardo não têm semelhanças físicas, mas apresentam profundas afinidades espirituais, a ponto de esse fato levar o leitor a reconhecer, no final da narrativa, uma identificação anímica entre os dois, que, por ser conflituosa, gerará um desfecho trágico ${ }^{12}$. Evidentemente a obra exige uma análise mais consistente, que extrapola a finalidade deste trabalho, e a leitura que se faria do uso do duplo neste caso mereceria maiores reflexões.

O duplo, segundo Derrida (Apud CUNHA), além dos diálogos com o Eu, expressa também uma relação de dependência em relação a ele, pois o valor essencial do duplo advém precisamente de seu modelo, do Eu, a partir do qual se institui. Em si mesmo, o duplo é neutro e transparente, não possui valor algum. Mesmo autônomo, ele próprio diferente do Eu original, seu valor é o que o modelo lhe empresta. $\mathrm{O}$ duplo não é nada sozinho. Entretanto, quando em presença de seu modelo, adquire importância e pode ser visto como "um suplemento, que, acrescentado ao modelo, pode substituí-lo, mas nunca ser seu igual, pois é, em boa verdade, sempre inferior ao modelo em termos de essência, mesmo quando o substitui" (CUNHA, in http://www2.fcsh.unl.pt/edt1/verbetes/D/duplo.htm, 2009).

\footnotetext{
${ }^{12}$ Importa notar que $A$ confissão de Lúcio é um exemplo de duplo exógeno conflituoso, mas há narrativas em que esse duplo exógeno é harmonioso, como é o caso de Menaechmi (Os Menecmos), que veremos logo adiante.
} 
A ideia de suplemento ultrapassa a lógica das oposições binárias metafísicas, já que, em lugar de afirmarmos que o Eu se opõe ao seu duplo, devemos dizer que o duplo é que acrescenta e substitui seu modelo, o Eu. Porém precisamos lembrar que nem sempre isso acontece nas narrativas. A esse respeito, Carla Cunha afirma: "eles são em si-mesmos, a sua própria différance de um, relativamente ao outro" (CUNHA in http://www2.fcsh.unl.pt/edtl/verbetes/D/duplo.htm, 2009). Essa prerrogativa de suplemento produz uma estrutura paradoxal, pois firma bases no princípio de que um sujeito pode ser si-mesmo e um Outro ao mesmo tempo e, no entanto, sendo Outro, não deixar de ser si-mesmo - traço principal do duplo. A natureza do duplo assume-se, então, como especular, alternando-se ambos, Eu e outro, ao realizar a sua figuração espectral.

Bravo, outra estudiosa desse mito, esclarece que o duplo simbolizou a homogeneidade desde a Antiguidade até o final do século XVI, quando funcionava enquanto semelhança física entre duas criaturas. Para ela, nesse período o mito era usado para efeitos de substituição ou de simples usurpação da identidade de outrem. Dentre os diversos escritores que se valeram do duplo como substituição está o latino Plauto, cuja peça Amphitruo ( $O$ Anfitrião) apresenta um enredo no qual o deus Júpiter se fantasia de Anfitrião, guerreiro tebano, e desce à terra para passar uma noite de amor com Alcmena, mulher do referido guerreiro. Nessa peça, temos a presença de personagens tomando a forma de outras personagens, formando um cômico quiproquó, em que o duplo é usado para explorar a ideia da permuta de identidades, sem introduzir qualquer crise identitária, diferente, portanto, do que ocorre em outros casos.

Um exemplo em que o Duplo desempenha o papel de usurpação da identidade é a peça plautina Menaechmi (Os Menecmos), que relata a história de dois irmãos gêmeos que são separados quando crianças e se reencontram depois de adultos. Um dos gêmeos usurpa involuntariamente a identidade do irmão e ambos só decifram o enigma no final da peça, quando se encontram e se recordam de seu passado comum. Na peça, os sósias ultrapassam o grau de semelhança e chegam ao da igualdade, já que são até confundidos um com o outro.

O que podemos verificar nessas duas ilustrações é que considerável parte da literatura anterior ao século XVII está voltada para exemplos em que personagens são consideradas unas, sem problemas ontológicos ou de fragmentação da identidade. Notamos que, nesse caso, a duplicidade exógena é harmoniosa, o que impede que a crise identitária se instale. 
Entretanto, novo passo foi dado após o século XVII, quando o Romantismo retoma o mito literário do duplo, agora a partir de seu aspecto heterogêneo. Segundo as considerações de Bravo, nesse período é abandonado o postulado da singularidade da identidade do sujeito e sua consequente busca por essa identidade, o que acarreta uma quebra de unidade do ser humano, uma fragmentação do eu.É da perspectiva da fragmentação da identidade que vemos instaurar-se o desdobramento do duplo homogêneo para o heterogêneo. Desse modo, o duplo, na heterogeneidade, torna-se várias vezes metáfora da busca da identidade.

No entanto, mesmo com o predomínio da heterogeneidade em nossa época, não podemos afirmar que o segundo estado acaba em definitivo com o primeiro, pois o duplo achará sua principal forma de existência nas relações dicotômicas. Na sua heterogeneidade, o homem busca afirmar a sua integralidade, assumindo, ilusoriamente, uma unidade, uma identidade homogênea, que precisa, a cada instante, ser (re)pensada e (re)construída.

O duplo aparece também como a dupla personalidade de um indivíduo mentalmente cindido. A melhor narrativa deste tipo é Strange case of Dr. Jekyll and Mr. Hyde, de Robert Louis Stevenson, que, no Brasil, é mais conhecida pelo título de $O$ Médico e o Monstro (2002). Na obra de Stevenson, Dr. Jekyll, ciente da dualidade humana, que transita ininterruptamente entre o bem e o mal, é fascinado pela ideia de obter vantagens disso. Descobre, então, uma droga que lhe permite criar, para si, uma personalidade à parte, portadora de todos os seus maus instintos, e denominada, na narrativa, de Mr. Hyde.

Jekill sabe da existência do outro por causa de sua fórmula e tenta desembaraçar-se de Hyde, sua malformada parte. Em um momento de descontrole, Jekill - já agora um espectro de Hyde - é parasitado pelo outro, que comete um crime horripilante. A partir desse acontecimento, Jekyll começa a transformar-se involuntariamente em Hyde, e a droga perde, aos poucos, o poder de restaurar sua forma original. A morte de Jekill - que é, consequentemente, a morte de Hyde - faz conhecer, sobrenaturalmente, o que ele era de fato: o corpo, que jaz encolhido no chão da casa de Jekyl, possui os traços hediondos de um outro (Hyde).

Quando, no século XIX, Freud descobre o inconsciente, a ideia de fragmentação da identidade experimenta uma considerável alteração. A descoberta foi uma verdadeira revolução, pois o homem, até então, acreditava que tinha pleno domínio sobre si, sem imaginar que suas ações estão diretamente ligadas a seu inconsciente. Foi por meio dos 
estudos de Freud que se revelou que a noção de sujeito implica um eu, formado também por um outro.

Em 1919, o pesquisador austríaco publica um ensaio intitulado Unheimlich, datado de 1919 (cf. FREUD, 1976, p. 237), que, na tradução para o português, recebe o nome de $O$ Estranho). Em seu ensaio, o criador da psicanálise examina a origem do medo e do horror do homem diante de situações sinistras ou inesperadas, concluindo que tais sentimentos são causados por um estado interior do indivíduo, uma espécie de fantasma do inconsciente. O psicanalista comenta situações e circunstâncias nas quais o familiar pode tornar-se estranho e assustador.

Tendo como ponto de partida os estudos de Jentsch ${ }^{13}$, Freud inicia seu texto apresentando uma vasta pesquisa em análise linguística. Suas reflexões não se iniciam pelo termo Unheimlich - estranho (um substantivo) -, mas por seu antônimo, o vocábulo Heimlich (que é um adjetivo), cujo significado mais comum em alemão é doméstico/familiar ${ }^{14}$.

Partindo do latim e passando pelo grego, pelo inglês, pelo francês, pelo espanhol, pelo italiano, pelo português e estendendo-se até ao árabe e ao hebraico, Freud se debruça sobre o termo Heimlich para constatar que ele possui, em alemão, três acepções diferentes: familiar e conhecido (já pouco usado na época de Freud); secreto ou oculto e inquietante ou estranho (atualmente pouco usado) ${ }^{15}$. Com base nessa constatação, o psicanalista nota que, do primeiro para o terceiro significado, há um paradoxo, já que, ao mesmo tempo, o vocábulo significa familiar e estranho. Como aponta Hanss, há um “ponto de ‘torção' em que Heimlich passa de 'familiar e conhecido' para 'inquietante e estranho'” (1996, p. 231). E essa torção ocorre justamente no segundo sentido. É como se houvesse uma gradação de significados em que o familiar transita para o secreto, até chegar ao estranho. Temos uma sequência do mais familiar ao mais estranho, num percurso de contiguidade que culmina em uma ambivalência, como comenta o pai da psicanálise:

Heimlich é uma palavra cujo significado se desenvolve na direção da ambivalência, até que finalmente coincide com o seu oposto, Unheimlich.

\footnotetext{
13، $S e m$ aceitar inteiramente esse ponto de vista do autor (Jentsch), tomá-lo-emos como ponto de partida para as nossas próprias investigações (...)" (FREUD, 1976, p. 284)

${ }^{14}$ Do alemão heim $=$ casa/lar.

${ }^{15}$ Por ser muito complexo o trabalho linguístico realizado por Freud no artigo em questão, já que ele possui extensa citação de um dicionário alemão, apresentando especiais dificuldades e indo muito além dos tópicos simplesmente linguísticos e por não termos familiaridade com a língua alemã, preferimos tomar como base Luiz Alberto Hanns, em seu Dicionário Comentado do Alemão de Freud, para as questões relativas aos termos Heimlich e Unheimlich. Para referência completa, ver a bibliografia, ao final do trabalho.
} 
Unheimlich é, de um modo ou de outro, uma subespécie de Heimlich. (FREUD, 1976, p. 283)

Freud explicita que o termo Heimlich, que oscila entre familiar e desconhecido, coincide com seu próprio antônimo, Unheimlich. Dessa dupla acepção, que paira sempre entre dois pólos, temos, então, as definições que Freud dá para Unheimlich: levemente estranho, assustador, inquietante, sinistro, esquisito, incômodo, estranhamento indefinível e desconfortável, dentre outras. O autor nos leva a ver que o termo Unheimlich está ligado ao ambiente do misterioso e do sobrenatural, porém não apresenta ligações de sentido opostas como as de Heimlich. Assim, o estudioso do inconsciente humano chega à conclusão de que o termo Heimlich está na mesma esfera semântica de Unheimlich.

Com base na análise etimológica de Heimlich e de Unheimlich, Freud conclui que as duas palavras, antes contraditórias por pertencerem a conjuntos de ideias diferentes, estão na verdade entrelaçadas, pois, além da ambiguidade, ambas expressam simultaneidade. Assim, a par da definição de Schelling de que "Unheimlich é tudo aquilo que deveria ter permanecido secreto e oculto, mas veio à luz" (FREUD, 1976, p. 282), psicanaliticamente, a ambiguidade é relacionada à sensação de inquietude do sujeito pelo retorno do material recalcado (portanto conhecido), o qual volta sob a forma de algo desconhecido e assustador.

Freud proporá que os termos dúplices em alemão funcionam psicanaliticamente para demonstrar o sentimento do sujeito que, ao presenciar situações e circunstâncias diferentes, acaba por passar da categoria do familiar para as categorias do estranho e do assustador.

Terminadas essas considerações, o escritor exemplificará melhor o conceito de estranho tomando como ilustração o conto $O$ homem da areia, do escritor romântico E.T.A. Hoffmann. Nele, o protagonista Natanael é atormentado ao longo de sua vida adulta pela presença sinistra de Coppola - um possível duplo do provável assassino de seu pai - e pela boneca Olímpia, um ser autômato (e, portanto, sinistro, mas estranhamente familiar) por quem ele se apaixona.

A partir desse conto, Freud faz uma leitura psicanalítica da personagem Natanael. Segundo essa leitura, o jovem vivia sob um processo de repressão, uma vez que seu medo de perder os olhos - lembrança de sua infância - seria, inconscientemente, o medo da castração. Conforme as palavras do próprio escritor: "Arriscar-nos-emos, portanto, a referir 
o estranho efeito do Homem da Areia à ansiedade pertencente ao complexo de castração da infância" (FREUD, 1976, p. 291).

Após as considerações sobre essa narrativa de Hoffmann, Freud volta sua atenção ao tema do duplo, constatando que, nessa temática, há dois fenômenos a analisar: o do mesmo e o do duplo. O fenômeno do mesmo diz respeito a uma impossibilidade instantânea de reconhecer a si mesmo, após o que o e $u$ apodera-se daquela imagem que é sua e transforma-a em um outro - o seu duplo. Freud afirma que o duplo - apesar de parecer estrangeiro, estranho a cada um de nós - nos acompanhou desde os tempos primordiais do funcionamento psíquico, estando sempre pronto a ressurgir e provocar uma sensação de inquietante estranheza. Exemplo significativo é o evento que aconteceu com o próprio Freud quando, de súbito, dentro da cabine espelhada de um trem, não reconheceu a própria imagem refletida em primeiro plano, o que provocou "mal-entendidos" e um "maureconhecimento" de si mesmo.

Ao se deter sobre o duplo, Freud liga-o ao fenômeno mental do recalcamento, que, por sua vez, se liga ao processo de estranha familiaridade, ou seja, um sentimento que cerca o sujeito sorrateiramente e que o leva a, no momento em que vê algo que conhece sua própria imagem, no caso do duplo -, ter um sentimento, uma sensação estranha - já que ele é um e não dois e, além disso, não pode encontrar ninguém que seja exatamente igual à sua imagem.

O escritor austríaco também liga a ideia de duplo ao processo de formação do ego, pois este tem "a função de observar e de criticar o eu (self) e de exercer uma censura dentro da mente, e da qual tomamos conhecimento como nossa 'consciência"' (FREUD, 1976, p. 294). Tal fato possibilita o entendimento do sentido paradoxal da relação eu/outro como algo também interior. Por outro lado, o fato de o eu saber da não existência real do seu duplo acaba por se tornar uma instância geradora de estranho. Ou, nas palavras de Carla Cunha, "o duplo é uma instância geradora de inquietante estranheza, porquanto o "eu" concebe este duplo como algo estrangeiro ou estranho a si-mesmo" (http://www2.fcsh.unl.pt/edtl/verbetes/D/duplo.htm, 2009). Mas, não sendo nada de novo ou desconhecido, ao ressurgir, assume-se como algo familiar e há muito estruturado em nossa mente. O duplo é um outro de si mesmo e é reconhecido pela sensação de estranhamento que é capaz de causar.

Além disso, a percepção de Freud de que há a passagem do duplo homogêneo para o duplo heterogêneo, modalidades de duplo mencionadas por Bravo (In: BRUNEL, 2000, 
p. 262), está registrada na afirmação de que o duplo "data de um estádio mental muito primitivo, há muito superado - incidentalmente, um estádio em que o 'duplo' tinha um aspecto mais amistoso" (Apud BRUNEL, 2000, p. 295). Assim, o criador da psicanálise parece solucionar, dentro de sua teoria, essa passagem, salientando que o amistoso (homogêneo) deu passagem ao inconciliável (heterogêneo) em um processo de progressão diacrônica. Por essa premissa, ele vê o duplo como um processo que se ancora na repetição involuntária de algo ou de uma situação (dejà vu).

A teoria psicanalítica proposta por Freud oferece sustentáculo para pensarmos a literatura e suas incursões pela temática do duplo. Se o sentimento de estranheza familiar é provocado pela repetição de um fato ou de algo que surge de forma persistente em nossa vivência, o duplo, enquanto processo estilístico que duplica a personagem, explora essa mesma repetição para causar um questionamento identitário. Em outras palavras, o Eu, pela observação de seu duplo, observa e repensa-se a si mesmo.

Foi a partir dessa formulação freudiana que surgiu uma área fecunda para os estudos realizados posteriormente por Bakhtin, principalmente no que diz respeito ao dialogismo ${ }^{16}$.

De acordo com Bakhtin (1992, p. 110), a identidade se constrói mediante as relações com o outro. O outro, na perspectiva bakhtiniana, é de suma importância para a formação do eu, pois este só existe por meio do outro e o outro é aquele que nos direciona, ou, nas palavras do teórico, “ocorre que nossa própria relação com a imagem externa não é de índole imediatamente estética, mas diz respeito apenas ao seu eventual efeito sobre os outros (...)" (2006, p.30). Bakhtin esclarece que só podemos definir nossa posição em relação ao outro, isto é, somos o que somos para e através do outro. Porém, na concepção bakhtiniana, não é possível que o outro seja, necessariamente, o duplo; entretanto, o duplo é, necessariamente, o outro.

Nessa concepção, o sujeito é uma função vazia, uma espécie de espaço que deve ser preenchido por diferentes indivíduos que o ocuparão ao participarem de sua formação identitária. Nas palavras do próprio Bakhtin

\footnotetext{
${ }^{16}$ Apesar de estarem vinculados quanto ao assunto do tema, a perspectiva freudiana não se equipara à bakhtiniana - tanto que um dos primeiros livros do círculo bakhtiniano será O Freudismo: um esboço crítico, no qual o autor se dedica a realizar uma crítica marxista aos postulados freudianos. Mesmo assim, é inegável que a leitura de Freud por Bakhtin trouxe ao menos um mote para que o teórico russo pudesse dissertar sobre a questão do dialogismo e suas diversas formas e funções.
} 
não tomo consciência de mim mesmo senão através dos outros, é deles que eu recebo as palavras, as formas, a tonalidade que formam a primeira imagem de mim mesmo. Só me torno consciente de mim mesmo, revelando-me para o outro, através do outro e com a ajuda do outro (Apud TODOROV, 1981, p. 148) ${ }^{17}$.

Essa preocupação com o Outro introduz, necessariamente, o conceito de sujeito no discurso e evoca, implicitamente, a ideia de duplo que ao sujeito se relaciona. Isso ocorre porque, ao se constituir, o sujeito incorpora e assume diferentes vozes sociais, duplicandose e, muitas vezes, sendo diversos em um único ser. Além disso, para ser sujeito, o Eu necessita se contrapor a um Outro, um Tu que faz as vezes de seu espelho invertido, possibilitando-lhe posições e contraposições em favor de sua justaposição a esse Outro. Dessa forma, o outro é indispensável à própria existência do ser. Sendo assim, uma reflexão sobre a identidade não pode deixar de priorizar a questão da duplicidade, pois é ela que ligará de maneira constitutiva o Mesmo com o seu Outro.

Vale lembrar que a figura do espelho é uma metáfora de perfeita justeza para o conceito de duplo da visão bakhtiniana ${ }^{18}$. Segundo o próprio escritor,

\begin{abstract}
contemplar a mim mesmo no espelho é um caso inteiramente especifico da minha visão externa. Tudo indica que neste caso vemos a nós mesmos de forma imediata. Mas não é assim; permanecemos dentro de nós mesmos e vemos apenas nosso reflexo (...) vemos o reflexo de nossa imagem externa mas não a nós mesmos em nossa imagem externa; a imagem externa não nos envolve ao todo, estamos diante e não dentro do espelho; o espelho só pode fornecer o material para a auto-objetivação, e ademais um material não genuíno. De fato, nossa situação diante do espelho sempre é meio falsa: como não dispomos de um enfoque de nos mesmos de fora, também nesse caso nos compenetramos de um outro possível e indefinido, com cuja ajuda tentamos encontrar uma posição axiológica em relação a nós mesmos; também aqui tentamos vivificar e enformar a nós mesmos a partir dos outros; daí a expressão original e antinatural de nosso rosto que vemos no espelho [e] que não temos na vida. (...) Ocorre que nossa própria relação com a imagem externa não é de índole imediatamente estética, mas diz respeito apenas ao seu eventual efeito sobre os outros - observadores imediatos - isto é, nós a avaliamos não para nós mesmos, mas para os outros e através dos outros. (BAKHTIN, 2006, p. 30-1; grifo nosso).
\end{abstract}

Apesar de extensa, a citação de Bakhtin é valiosa porque estabelece um diálogo com o fenômeno do duplo, exemplificado pela questão da imagem especular. Como explicita Eco (1989, p. 12) "o espelho é um fenômeno-limiar, que demarca as fronteiras entre o imaginário e o simbólico". Somando o pensamento bakhtiniano à ideia de

\footnotetext{
${ }^{17}$ Todas as traduções dessa obra, cujo original é francês, são de nossa responsabilidade.

${ }^{18}$ Para não causar problemas de ordem técnica ou analítico-interpretativa, usaremos o vocábulo "espelho" segundo o define Eco (1989, p. 13-14): "Definimos inicialmente como espelho qualquer superfície regular capaz de refletir a radiação luminosa incidente. (...) Entendemos por espelho plano uma superfície que fornece uma imagem virtual correta, invertida (ou simétrica), especular (de tamanho igual ao objeto refletido), sem as chamadas aberrações cromáticas".
} 
especularidade de Eco, podemos notar que, na imagem especular, estão, ao mesmo tempo, o reflexo e a refração do sujeito, que se vê por meio da imagem. Assim como ele se contempla a si mesmo nessa imagem, ao mesmo tempo não se vê: a imagem não é o próprio sujeito que se olha, mas apenas uma imagem sua - reflexo e, ao mesmo tempo, refração. Se, nas palavras do próprio Bakhtin, "o espelho só pode fornecer o material para a auto-objetivação e, ademais, um material não genuíno" (2006, p. 31), ele não apresenta o sujeito por completo por meio da imagem que projeta, mas sim uma espécie de duplo, um ser outro que, sendo imagem do sujeito, não é o sujeito em si.

Essa falsidade à qual se refere Bakhtin está situada exatamente no cerne do conceito de duplo, ou seja, ao mesmo tempo em que parece ser, ele não é.

No acontecimento da autocontemplação interfere um segundo participante, um outro fictício, um autor sem autoridade, não fundamentado; eu não estou só quando me contemplo no espelho, estou possuído por uma alma alheia (BAKHTIN, 2006, p.31).

Então, tanto o duplo quanto a imagem especular possuem a mesma característica, a de parecer, mas não ser. E, além disso, ambos servem para o reconhecimento da própria identidade do sujeito, já que permitem que esse sujeito encontre "uma posição axiológica" (BAKHTIN, 2006, p.31), que só pode ser encontrada na relação com o outro. Dessa posição teórica é que surge o pressuposto de que o processo de autocompreensão só se pode realizar mediante a alteridade, isto é, mediante a aceitação e percepção dos valores do outro. Por fim, nas linhas abaixo transcrevemos a conclusão de Bakhtin sobre a questão especular:

\begin{abstract}
Ademais, às vezes essa alma alheia pode ganhar consistência a ponto de atingir certa autonomia: o despeito e certa exacerbação de ânimo a que vem juntar-se nosso descontentamento com a imagem externa dão consistência a esse outro autor possivel da nossa imagem externa; é possível desconfiarmos dele, odiá-lo, querermos destruí-lo: ao tentar combater certa avaliação possível totalmente formadora, eu lhe dou consistência a ponto de levá-la a uma autonomia de pessoa quase localizada na existência. (BAKHTIN, 2006, p. 31. Grifos nossos)
\end{abstract}

Constatamos, pelas reflexões de Bakhtin, que, ao ver-se no espelho, o sujeito acaba por gerar uma outra pessoa por meio da sua imagem refletida. Ele mira o virtual, uma simia naturae que está dentro do espelho, o que lhe possibilita conferir a essa imagem consistência e forma e, nesse processo, outrar-se $e^{19}$. Ele dá a essa imagem uma autonomia que a eleva quase à categoria de pessoa localizada na existência. Como completa Eco, "no

\footnotetext{
${ }^{19} \mathrm{O}$ neologismo outrar faz-se necessário para expressar esse momento em que o duplo (essa alma alheia de que fala Bakhtin) atinge certa autonomia e adquire, em relação ao sujeito, sua própria identidade.
} 
momento em que se delineia a 'virada' do eu especular para o eu social, o espelho é a 'encruzilhada estrutural' ou, como dizíamos, fenômeno-limiar' (1989, p. 13, grifos do autor).

As reflexões acima nos levam a reconhecer que o duplo é uma instância sempre presente e, mais que isso, uma instância que gera opiniões por parte de seu outro, já que é por meio dessa imagem que o sujeito constrói sua identidade. Ou, citando novamente o teórico russo:

Contemplar a mim mesmo no espelho (...) permanecemos dentro de nós mesmos e vemos apenas o nosso reflexo, (...) vemos o reflexo de nossa imagem externa mas não a nós mesmos em nossa imagem externa; (...) estamos diante e não dentro do espelho; o espelho só pode fornecer o material para a autoobjetivação, e ademais um material não genuíno. (BAKHTIN, 2006, p. 30)

O outro, representado em uma primeira instância pela própria imagem especular, é quem fornece nossa primeira duplicação, a qual tem o poder de permitir ao "copiado" a sua auto-objetivação, ou seja, sua imagem formada exteriormente para o mundo. Como nota Bakhtin, a imagem externa e virtual que o espelho proporciona a quem nele se olha não possui status de veracidade; é, antes de tudo, uma forma distorcida da auto-objetivação do sujeito, ou, em outros termos, uma duplicação especular do sujeito.

O diálogo entre o eu e o outro, relacionado ao tema do duplo, reflete uma inquietude ontológica e, ao mesmo tempo, aponta para uma profunda reflexão sobre a vida. Em Bakhtin, "o homem não tem território interior soberano, ele está todo e sempre na fronteira. Ao olhar para dentro de si mesmo, ele olha o outro nos olhos ou pelos olhos do outro" (BAKHTIN, 2006, p.212). É o homem no seu limiar, entendendo sua coexistência com o outro. O outro dialógico de Bakhtin é condição do discurso e da autoconsciência. Nele está a fronteira interior, em que o sujeito luta pela sobrevivência, buscando sua identidade. Em literatura, tal fato desencadeia um movimento contínuo, que ora se confunde com, ora se contrapõe à personagem, em sua busca por descobrir se está a travestir-se em outro, a dividir-se, a duplicar-se ou a deixar de ser ela mesma para assumir a outra identidade, o que reitera as palavras de Bakhtin: "nós a avaliamos [a identidade] não para nós mesmos, mas para os outros e através dos outros" (BAKHTIN, 2006, p. 31).

Importa perceber que esse outro, mais uma imagem especular do que uma pessoa, mais do que um duplo criado pelo sujeito para que se entenda melhor, mais que uma diferição criada pelo sujeito em relação a um outro, é uma concretização do duplo no mundo: 
[...] no acontecimento da autocontemplação, interfere um segundo participante, um outro fictício, um autor sem autoridade não fundamentado; eu não estou só quando me contemplo no espelho, estou possuído por uma alma alheia. Ademais, às vezes essa alma alheia pode ganhar consistência a ponto de atingir certa autonomia: o despeito e certa exacerbação de ânimo a que vem juntar-se nosso descontentamento com a imagem externa dão consistência a esse outro - autor possível da nossa imagem externa; é possível desconfiarmos dele, odiá-lo, querermos destruí-lo: ao tentar combater certa avaliação possível totalmente formadora, eu lhe dou consistência a ponto de levá-la a uma autonomia de pessoa quase localizada na existência. (BAKHTIN, 2006, p.31).

A imagem especular e o espelho, por contiguidade, são elementos de reflexão (nos dois sentidos que a palavra expressa) que possibilitam essa consistência do alheio, o cotejo entre o real e sua possibilidade de duplicação. Essa consistência, constitutiva do ser humano, revela, à revelia, a busca de si, a busca de si no outro, o espelhar de uma identidade que talvez seja fugaz, quem sabe inapreensível, mas que é certamente misteriosa.

Encerrando suas reflexões sobre a questão do outro na imagem especular (mas não sobre a questão do duplo, tema recorrente nos escritos de Bakhtin), o pensador russo vai comparar a imagem especular com a imagem da máquina fotográfica. Segundo ele,

A fotografia propriamente dita também só oferece material para cotejo, e nela não vemos a nós mesmos mas tão-somente o nosso reflexo sem autor; é verdade que esse reflexo já não reproduz a expressão do outro fictício, ou seja, é mais puro que o reflexo no espelho, no entanto é percebido de forma aleatória, artificial, e não expressa nossa diretriz volitivo-emocional no acontecimento da existência (BAKHTIN, 2006, p. 32)

Do ponto de vista de Bakhtin, a imagem fotográfica permite também a reflexão sobre um outro eu, um duplo do sujeito enquanto elemento de cotejo. Entretanto, diferentemente do espelho, tal qual a imagem especular, a imagem fotográfica não revela a presença de nossa consistência pelo alheio. Ela tão-somente reproduz fielmente a forma do sujeito fotografado, sem nenhuma preparação ou força-motriz de revelação da identidade humana. Dito de outra forma, o espelho congelante é chapa fotográfica.

Tais questões mostram que "o homem tem uma necessidade estética absoluta do outro, (...) que é capaz de criar para ele uma personalidade externamente acabada; tal personalidade não existe se o outro não a cria" (BAKHTIN, 2006, p. 33). O outro é revelado pelo pensamento bakhtiniano como o verdadeiro formador da imagem do Eu, pois é somente por meio dele que o eu se compreende.

Dessa perspectiva, concluímos que a identidade do sujeito é um constructo, uma personalidade em processo de construção - gerúndio de uma vida - que se esfacela a cada nova abordagem que o outro faz de si. Fênix sempre renascida, ela nos conduz ao mais 
profundo de nosso ser para responder à minotáurica e irrespondível pergunta que persegue todo ser humano: quem sou eu?

O tema do duplo e o esfacelar da personalidade, tal como são focalizados por Bakhtin, expressam a visão da imperfeição e do inacabamento do ser humano, tema que, permeado pela questão da duplicidade, circula pela literatura desde suas mais remotas origens. Isso porque, como bem esclarece Eco,

O fato de a imagem especular ser, entre outros casos, de duplicatas, o mais singular, e exibir características de unicidade, sem dúvida explica por que os espelhos têm inspirado tanta literatura: esta virtual duplicação dos estímulos (...) este roubo da imagem, esta tentação contínua de considerar-me um outro, tudo, faz da experiência especular uma experiência absolutamente singular, no limiar entre percepção e significação. (1989, p. 20)

Se a literatura é o lugar por excelência da experimentação, a imagem especular é um topos perfeito para que ela construa suas experiências. Sendo o espelho um objeto que permite ver-nos como os outros nos veem, ele é um elemento que, em sua "extensividadeintrusividade, não somente nos permite olhar melhor o mundo, mas também ver-nos como nos veem os outros (...)" (ECO, 1989, p. 18), melhor, ícone perfeito para a literatura que quer mostrar ao ser humano sua face e atitudes por meio de uma reflexão fíccional dos fatos. Portanto, podemos pensar o espelho quase que como metáfora de Literatura.

O espelho, duplicata do campo estimulante, reflete a função do duplo na área literária. Já o duplo é um mito que, por mais discutido que seja em diversas áreas do conhecimento, é literário. Ele é apreendido sempre por meio de uma narrativa ou de narrativas. É por intermédio dessas narrativas e na obscuridade de suas revelações poéticas que temos uma propagação de sentidos e funções que nos envolve e que nos reúne em torno do mito, mas que, ao mesmo tempo, nos vertigina com suas dificuldades e pluralidade de sentidos. Por fim, esse tema dissemina-se pelas mãos de diversos escritores, como Shakespeare (A Comédia dos Erros), E.T.A. Hoffman (entre seus escritos, o mais famoso é O Homem da Areia e Os elixires do diabo), Edgar Allan Poe (O Gato Preto, William Wilson), Oscar Wilde (O retrato de Dorian Gray), Maupassant (O Horla), Mário de Sá-Carneiro (Céu em Fúria, A Confissão de Lúcio), Nerval (Aurélia), Jules Gracq (No castelo de Argol), Jorge Luis Borges ( $O$ Outro e $O$ Livro de Areia), Murilo Rubião ( $O$ Pirotécnico Zacarias) e Carlos Fuentes (Aura), Júlio Cortázar (Distante) e Miguel Angel Astúrias (Leyendas de Guatemala), Almeida Faria (O Conquistador) Alexandre Pinheiro 
Torres (O Meu Anjo Catarina), Dostoievski ( $O$ Duplo ${ }^{20}$ e $O s$ Irmãos Karamázov) e José Saramago (O Ano da Morte de Ricardo Reis, História do Cerco de Lisboa, O Evangelho segundo Jesus Cristo, A Caverna, O Homem Duplicado e A Viagem do Elefante) entre outros.

É a esse jogo complexo de teorias acerca do tema do duplo que recorreremos no decorrer de nossa análise. Nela buscaremos encontrar um veio interpretativo tanto para $O$ Anfitrião quanto para $O$ Homem Duplicado.

De posse dessas considerações teóricas, procuraremos verificar como as duas obras que compõem o corpus deste trabalho conversam entre si.

\footnotetext{
${ }^{20}$ Algumas edições brasileiras trazem $O$ Sósia como tradução dessa obra.
} 


\title{
CAPÍTULO II \\ O CAOS DA ORDEM: PLAUTO E SUA (RE)LEITURA DO MITO DE ANFITRIÃO.
}

\author{
Postquam est morte aptus Plautus \\ comoedia luget, scaena est deserta, \\ dein risus iocusque et numeri innumeri \\ simul omnes conlacrimarunt. ${ }^{21}$
}

Epitáfio de Plauto

\subsection{Plauto: o Mito e a Peça}

Sabemos que todo texto envolve seus hipotextos $\mathrm{e}$ isso dá origem à intertextualidade ${ }^{22}$. Essa é uma característica presente na literatura desde a Antiguidade e vem sendo cada vez mais explorada pela contemporaneidade. Como esclarece Julia Kristeva, "todo texto se constrói como um mosaico de citações, todo texto é a absorção e a transformação de um outro texto" (1974, p.64). A intertextualidade é, portanto, o modus faciendi de incorporação de um texto em outro, ou reproduzindo o sentido incorporado, ou transformando-o. Esse processo de produção ficcional que se apropria de textos preexistentes revela diversas facetas da criação literária.

Uma das relações intertextuais é a que a obra de Plauto - Amphitruo - mantém com o mito grego de Anfitrião. Assim, nosso intuito, neste capítulo, volta-se para a investigação, por meio da teoria da intertextualidade, das relações intertextuais que a peça plautina Amphitruo mantém com o mito grego de Anfitrião. Procuraremos examinar e distinguir os conceitos dos termos acréscimo, supressão, inversão e deslocamento, para, posteriormente, aplicá-los na análise dos dois textos citados - o mito e a peça.

Para tal, nos valeremos principalmente das teorias expostas por Gérard Genette em seu livro Palimpsestos (2009) e por Claude Bouché em seu Lautréamont: du lieu commun à la parodie (1974).

À guisa de apresentação, podemos dizer que o comediógrafo Titus Maccius Plautus nasceu em Sársina, na Úmbria, região da Itália, muito provavelmente no ano de 254. a.C.

\footnotetext{
21 "Depois que Plauto foi atingido pela morte, / a comédia chora, o palco fica abandonado; e então o riso, / o jogo, o sarro, e os ritmos inumeráveis, / todos eles choraram”. Tradução livre, sob nossa responsabilidade.

${ }^{22}$ A intertextualidade está sendo considerada, neste contexto, nos termos de Gérard Genette, como "presença literal (mais ou menos literal, integral ou não) de um texto noutro" (1986, p. 97).
} 
Porém muito do que sabemos de sua vida é lendário. Considerado o maior comediógrafo da Roma antiga, é oriundo de berço humilde e veio para Roma ainda jovem. Segundo documento escrito por Aulo Gélio, logo após sua chegada à cidade, ingressou numa companhia teatral, tornando-se, algum tempo depois, senhor de uma boa fortuna, que perdeu no comércio marítimo e nas viagens que fez pelo Mediterrâneo. Arruinado, teve de voltar a Roma e sujeitar-se ao duro trabalho de moleiro para garantir o seu sustento. Entre um intervalo e outro da penosa profissão, compôs três comédias, das quais sabemos o nome de apenas duas: Saturio (O Comilão ou $O$ de Barriga Cheia) e Addictus (O Escravo por dívidas).

As três peças, revelando o gênio do poeta, alcançaram tanto sucesso que lhe deram fama, liberdade e dinheiro. Tornou-se, então, grande teatrólogo em Roma, atuou como palhaço em algumas farsas atelanas ${ }^{23}$ e exerceu alguns papéis em mimos ${ }^{24}$, experiência que deixou profundas marcas em seu teatro. Viveu personagens em algumas de suas comédias e dedicou-se inteiramente à composição da palliata, gênero de temas e personagens gregas $^{25}$. A palliata de Plauto foi grandemente elogiada por Varrão, Cícero e Élio Estilão, atravessando os séculos e despertando o interesse de comediógrafos e estudiosos de várias épocas.

Não sabemos ao certo se era livre ou escravo liberto, embora a primeira hipótese seja apontada pela crítica como a mais plausível. Sua língua materna era o umbro, mesclado talvez de elementos célticos, mas conhecia o grego e tinha grande domínio do latim, adquirido na Úmbria latinizada ou em Roma, para onde se supõe ter ido bem jovem. Cícero diz que seu latim é genuíno, é a própria voz do povo e da cidade de Roma (Vox romani generis urbisque propria) (Apud PARATORE, 1980, p. 50).

Plauto estreou no teatro cômico aos quarenta anos, a julgar pela data da comédia mais antiga, fixada em torno de 215 a.C., e somente o abandonou aos setenta, quando, por volta de 185 a.C., levou ao palco a Casina, considerada pela crítica como sua última peça. Nos seus prováveis trinta anos de carreira, Plauto dedicou-se quase que exclusivamente à comédia. Seu período de maior produção literária ocorreu por volta de 204-194 a.C.,

\footnotetext{
${ }^{23}$ Espécie de farsa popular vivida por personagens fixas e burlescas. Para mais detalhes, cf. CARDOSO, 2003 , p. 37.

24 "Uma das primeiras formas do primitivo teatro latino. Caracteriza-se pela presença do gesto mímico, da expressão corporal e da dança (...)" ( Ibidem, p. 38)

${ }^{25}$ De todas as peças de Plauto, apenas $O$ Anfitrião, como comentaremos mais adiante, não é uma comédia palliata, e sim uma fabula rintônica.
} 
portanto entre os seus cinquenta e sessenta anos de idade.

Faleceu provavelmente em Roma, no ano de 184 a. C., data apresentada por Cícero no Brutus (1966, p. 60) e aceita pela maioria dos especialistas modernos que se dedicaram ao estudo da vida e obra do comediógrafo latino.

Plauto teve seus enredos, personagens e ambientações copiados de autores da Nova Comédia Grega, como Menander, Filemon e Diphilus, porém introduzindo elementos de canto e dança e buscando, por meio de sua constante reflexão, transcender aqueles autores, dando a seus escritos uma alma itálica, totalmente nova e compatível com a realidade latina. Isso foi conseguido graças a sua convivência com a plebe cultivadora do accentum italicum $^{26}$ e à prática do teatro popular cômico-musical etrusco. Herdou da comédia ática nova o estereótipo que esta possuía tanto nos temas quanto nos tipos e na trama. Os tipos eram constantes, sempre os mesmos, mas sua criação elaborou a escolha apropriada do termo plebeu, o jogo de palavras, o linguajar de bobo, as facécias, as composições esdrúxulas, os hibridismos, as digressões inesperadas. Essas características prendiam a atenção dos espectadores, provocando-lhes surpresas contínuas e sonoras gargalhadas.

A comédia ática nova integrava ainda o coro, se bem que restrito às funções modestas de breve intermezzo, que Plauto soube utilizar muito bem. Com métrica elaborada e linguagem coloquial, sua obra busca reproduzir a vida cotidiana dos romanos, retratando seus aspectos mais jocosos. O que se destaca em suas comédias são os numeri inumeri (variedade métrica), os cantica, que fazem que suas peças se tornem comédias musicais, operetas cômicas, pantomimas. A variedade métrica, entretanto, é a mais fascinante de suas características, além da vivacidade caprichosa dos expedientes linguísticos.

Suas fábulas são, em geral, baseadas em casos de amor ou confusões decorrentes de troca de identidades e apresentam grande originalidade no tratamento dos temas. As personagens são de origem popular: escravos mentirosos, ladrões, velhos, soldados fanfarrões, cortesãs etc. Em Plauto, o acentum italicum encontra-se nos escravos, nos proxenetas, nos parasitas e nas prostitutas, misturados ao ritmo frenético da dança priapesca.

Plauto é, atualmente, o autor preferido dos doutos e dos literatos, sobre os quais exerce grandíssima influência. Como já expressara Quintiliano (Apud PARATORE, 1980,

\footnotetext{
${ }^{26}$ A expressão Acentum Italicum refere-se, mais exatamente, à romanização que os escritores realizavam nas obras estilizadas da realidade grega.
} 
p. 57), “as musas falariam no estilo de Plauto, se quisessem falar latim”. Portanto, é considerado o maior comediógrafo de Roma. De suas vinte e uma peças, vinte são fabulae palliatae $^{27}$, inspiradas ou reelaboradas a partir da comédia ática nova ${ }^{28}$. Somente o Amphitruo é considerado uma fabula rhintonica ${ }^{29}$, espécime de teatro que se caracteriza por ser satírico e ter enredo que aborda temas míticos.

Sendo uma peça escrita por um comediógrafo, mas filiada à fabula rhintonica, o Amphitruo traz em seu bojo temas e elementos constantemente reatualizados pela contemporaneidade, os quais procuraremos resgatar neste estudo. Dessa perspectiva, o primeiro passo será, então, pensar o mito grego de Anfitrião para saber como Plauto realizou a releitura. Para tanto, elencaremos os elementos que são comuns ao mito e à peça e que, de alguma forma, contribuem para respondermos às formulações propostas neste trabalho. A seguir, resumimos o conteúdo do mito.

Segundo a mitologia grega, Zeus, como consta da narração de Hesíodo, havia decidido "ter um filho que fosse um dia o defensor, simultâneo, dos imortais e dos humanos" (1999, p. 85). O deus supremo do Olimpo escolhe como mãe de seu rebento a mais bela, virtuosa e inteligente das jovens, Alcmena, a então futura esposa do general Anfitrião.

Alcmena $^{30}$ - cujo nome provém do grego $A l k m h$ (nh (a vigorosa, ou afastar o perigo/inimigo) ${ }^{31}$ - era prima de Anfitrião $^{32}$ - do grego Amphitrýon (o que provoca devastação por toda parte) -, cada um nascido de um dos filhos de Perseu; a primeira, filha

\footnotetext{
${ }^{27}$ A fabulla palliata foi criada pelos romanos no século III a.C. Esse gênero de comédia, que usava como vestimenta o pallium grego - espécie de manto, muito comum na Grécia -, em sua origem, mantinha estreitas ligações com a comédia nova helênica do século IV a.C. A comédia paliata buscava seus temas e histórias nos mitos gregos da Antiguidade.

28 Segundo Cardoso, a comédia nova "tem por assunto fatos corriqueiros e engraçados, ocorridos entre pessoas pertencentes às mais variadas classes sociais. É uma comédia de costumes, que explora, sobretudo, o amor contrariado que, após algumas peripécias vividas pelas personagens, consegue triunfar, num final feliz." (2003, p. 26).

${ }^{29}$ A denominação provém do nome de Rínton, "um grego de Siracusa ou de Tarento que, nos fins do século IV, tinha dado impulso, com seus flíacos, à paródia mitológica, cara à poesia grega clássica, com o drama satírico e a comédia antiga, mas florescente, desde o tempo de Epicarmo, sobretudo na grande Grécia, onde encontrou expressão também nas artes figurativas, na celebre cerâmica ápulo-lucana." (PARATORE, 1980, p. 44).

${ }^{30}$ Alc-, de alk (repelir o inimigo, defender) + mena, de mene (complemento do nome).

${ }^{31}$ Para a etimologia, a construção da narrativa mitológica e as correspondências dos nomes aqui explicitados, utilizamos as indicações de Paul Harvey em Dicionário Oxford de Literatura Clássica, de Georges Hacquard em Dicionário de Etimologia Grega e Romana e de Junito de Souza Brandão em Dicionário MíticoEtimológico da Mitologia Grega. Para mais informações cf. bibliografia.

${ }^{32}$ Anfi-, de amph (de um e de outro lado) + trião, de tryo, forma poética de trycho (gastar pelo atrito).
} 
de Eléctrion, rei de Micenas, e o segundo, filho de Alceu e de Astidameia.

Quando Eléctrion é atacado pelos filhos de Ptéreas, rei de Tafos, tem seu país arrasado, suas manadas tomadas como despojo e seus filhos brutalmente assassinados. Como vingança, resolve ele mesmo ir ao ataque de Ptéreas em sua ilha - Tafos. Nessa ocasião, Eléctrion confia a Anfitrião seu trono e a guarda da filha Alcmena. No entanto, antes da partida de Eléctrion, Anfitrião decide resgatar as manadas roubadas de seu tio. Porém, no momento em que conduz os animais de volta para Eléctrion, uma vaca enfurecese e avança em direção ao rei, obrigando Anfitrião a atacá-la com um golpe de arma na cabeça. Eléctrion é salvo por seu genro; contudo, a arma usada por Anfitrião ricocheteia e termina por ferir o rei. Eléctrion cai morto no mesmo instante. Por causa do assassinato, Anfitrião é banido da cidade por seu tio Estênelo - rei de Argos - e obrigado a exilar-se em Tebas, levando consigo a virgem Alcmena, por quem está apaixonado e com quem pretende casar-se.

Ainda que apaixonada por Anfitrião, a jovem princesa só aceitaria se casar com seu primo com a condição de que o noivo primeiro vingasse os irmãos dela, mortos na guerra contra Ptéreas, e realizasse o desejo de vingança do pai. A fim de purificar-se do homicídio cometido, Anfitrião, com a ajuda do rei Creonte, obtém a aliança dos tebanos e, com contingentes provindos de várias regiões de Hélade, invade a ilha de Tafos.

Durante essa ausência de Anfitrião, que vai à guerra vingar seus cunhados, Zeus, vai ao palácio de Alcmena Como sabia da fidelidade absoluta da princesa a Anfitrião, o deus do Olimpo, para realizar seu intento, assume as feições de Anfitrião e metamorfoseia seu filho Mercúrio em Sósia; feito isso, apresenta-se à jovem como seu futuro marido na noite anterior ao retorno de Anfitrião da guerra. Contando para a jovem bela os detalhes da batalha empreendida e dos golpes certeiros que usara para ganhar a expedição militar, Zeus conquista a credibilidade da moça. Como prova definitiva de sua identidade, o deus travestido em marido apresenta a Alcmena uma taça de ouro espoliada da mesa do rei Ptéreas, o monarca derrotado, e a oferece à amada, narrando-lhe longamente os incidentes da campanha. Por meio de tal agrado, o deus realiza seu intento e consegue seduzi-la. Foram setenta e duas horas de amor, já que, atendendo ao pedido do pai, Apolo, por três dias consecutivos, não percorre o céu com o carro do sol e, durante essa noite forçosamente prolongada, o deus dos deuses ama ardentemente Alcmena.

No dia seguinte à longa noite de amor que Zeus passa com Alcmena, Anfitrião retorna à cidade e estranha a reação da noiva, que o trata com acolhimento pouco caloroso, 
visto que acreditava já o haver encontrado na noite anterior. Anfitrião consulta o adivinho Tirésias, que lhe esclarece o ocorrido. Irado, Anfitrião coloca a jovem numa enorme pira à qual ateia fogo, mas a labareda é detida pela intervenção de Zeus, que envia uma chuva torrencial e apaga a fogueira. Compreendendo o sinal e, graças à fala do deus, o guerreiro reconsidera sua atitude, casa-se com Alcmena e consuma seu amor por ela em sua primeira noite de núpcias. Com tantas noites de amor com maridos diferentes, Alcmena gera de seus dois amantes dois filhos: Héracles ${ }^{33}$, fruto de seu encontro com Zeus, e Íflicles, filho de Anfitrião.

Reza o mito que, para saber qual dos dois era seu filho, Anfitrião introduziu no berço dos meninos "duas grandes serpentes. Íficles assustou-se, mas Héracles, com dez meses apenas, asfixiou os monstros. Assim se revelou a origem humana de Íficles e a origem divina de Héracles" (GRIMAL, 1993, p. 31). Outra versão diz que foi Hera, por ciúmes, quem introduziu as serpentes no berço das duas crianças.

Inicialmente, Anfitrião cuida pessoalmente da educação de seu filho adotivo, depois o entrega aos cuidados de um professor de música, mas a natureza do rapaz é muito violenta e Anfitrião o manda para os campos a fim de guardar-lhe os rebanhos. Durante sua permanência como pastor, Héracles pratica sua primeira grande façanha, derrotando o terrível leão do monte Citerão, que há tempos assombrava os rebanhos da cidade. Anfitrião pereceu heroicamente, lutando ao lado do seu filho contra os mínios, comandado por Ergino, rei de Orcômeno, cidade vizinha de Tebas. (cf. BRANDÃO, 1991, p.73).

Este é, resumidamente, o mito de Anfitrião, que acaba por gerar um novo significado para os vocábulos anfitrião e sósia. O primeiro passa a significar, por antonomásia, "aquele que recebe em casa". O mesmo ocorre com "sósia", que significa “cópia humana” ou “duplo de outrem” (BRANDÃO, 1991, p. 74).

Durante muitos anos, o mito circula de boca em boca e é por diversas vezes retomado ao longo dos séculos. Segundo afirmam alguns estudiosos, "vão para perto de oitenta as obras teatrais que se inspiraram, de alguma forma, nesse mito, na cola, todas, da primeira que conhecemos, o Amphitruo de Plauto" (PETERLINI, 1994, p. 319). Sabem-se perdidas peças que versam sobre o tema: Alcmena, de Ésquilo (), Anfitrião, de Sófocles, e outra versão de Anfitrião, de Eurípedes.

Apesar de haver referências a Alcmena e a Anfitrião na Ilíada (canto XIV, 323 e

\footnotetext{
${ }^{33}$ Herácles é o correspondente grego para Hércules. Como o mito de Amphitruo é genuinamente grego, preferimos manter os nomes gregos, ao invés de latinizá-los, como deveria ser o comum.
} 
ss.; canto XIX, 96 e ss.), na Odisseia (canto XI, 266 e ss.), em um hino homérico (canto XV) a Hércules e na Teogonia, de Hesíodo, nada é muito explorado. Não se diz nada sobre o encontro dos pais de Hércules, nada sobre o nascimento do semideus, nada sobre a guerra contra os teleboanos nem sobre a existência de Sósia. É em Hesíodo, em um poemeto de 480 hexâmetros denominado $O$ escudo de Hércules, que o mito aparece na forma como o conhecemos hoje, "uma conciliação, ao que parece, das lendas argivas com as tebanas sobre o nascimento de Hércules" (PETERLINI, 1994, p.319).

Como não possuímos as comédias gregas sobre o mito em que Plauto teria se inspirado, só nos resta crer que foi o escritor latino o primeiro a adicionar na história o par de semelhantes Anfitrião-Júpiter e Sósia-Mercúrio. Essa disposição de pares na década de 70 do século passado está presente nos seminários de Lacan (XXI, Sósia), além de se tornar uma história imortal dentro da literatura ocidental.

Quando Plauto retoma o mito para com ele interagir, sua posição não será a de mero copista, mas a de um escritor que adapta o já conhecido e o mescla a elementos que a estrutura da tragicomédia exige. À época plautina, já existia um grande documento que analisa a questão das peças teatrais - A Poética, de Aristóteles - que será a base da construção de sua peça. Passemos, agora, ao texto de Plauto, Amphitruo.

A ideia central está na apresentação do deus senhor do Olimpo formulando uma estratégia para usufruir do leito da mortal Alcmena, esposa do general tebano Anfitrião, enquanto este guerreia contra o rei Ptéreas, chefe dos Teleboas. Aproveitando a ausência de Anfitrião, Zeus desce à terra e rouba a forma do general, tornando possível que Alcmena o aceite em seu leito. A ação divina é bem-sucedida graças à ajuda do filho Mercúrio, que também rouba a forma de um humano, Sósia - o escravo e mensageiro de Anfitrião. O deus do Olimpo faz com que a noite pare para poder, por mais tempo, usufruir da hospitalidade de Alcmena. A mando de seu dono, o verdadeiro Sósia chega à casa de Anfitrião para trazer notícias do acampamento de guerra. Nesse momento, entra em ação Mercúrio (travestido de Sósia) para proibir o copiado de entrar em ação, o que confere sucesso ao plano de Zeus. O resultado desse encontro foi que Sósia viu, diante de si, uma imagem idêntica à sua, o que acaba por gerar uma confusão cômica e que só é descoberta ao final da trama. Essa confusão é acompanhada por um alto grau de tensão e isso caracteriza a peça como tragicomédia.

Um exemplo desse alto grau de tensão é expresso no diálogo que Zeus mantém com Anfitrião e que transcrevemos a seguir: 
Acalma-te Anfitrião, eu estou aqui para te ajudar, assim como a todos os teus. Nada tens a temer. Aos adivinhos e arúspices, manda-os todos de volta: o passado e o futuro, lhes direi muito melhor que eles, visto que eu sou Júpiter. Em primeiro lugar, sabe que obtive os favores de Alcmena e dessa união ela ficou grávida de um filho meu. Teu era já o filho que ela carregava ao ventre, quando foste para a guerra: de um só parto ela deu à luz aos dois meninos ao mesmo tempo. Um deles, o que foi concebido por meu sangue, te cobrirá de imortal glória com os seus feitos. Quanto a ti, regressa à harmonia de outrora com Alcmena: ela não merece que a culpem; o que ela fez, fui eu quem a obrigou a isso. Agora, volto aos céus (PLAUTE, 1970, p. 121-22) ${ }^{34}$.

O trecho demonstra a tensão do texto plautino. Essa tensão, expressa pelo pequeno - embate entre Anfitrião e Júpiter é, na verdade, o elemento que sustém a trama. Ele comporta uma característica especial, a de poder manter tudo dentro da conformidade. Assim, nada é mudado no final da trama, tudo permanece tal como estava antes. Essa característica imprime um tom que orientará toda a peça, permitindo que o embate seja desfeito e desemboque na unicidade.

Por fim, uma última informação se faz necessária antes de iniciarmos a análise da obra. Por se tratar de um texto de domínio universal e por ter diversas interpretações e versões apócrifas, resolvemos adotar o texto de Ernout (Comédies, 2001) como base para nossa pesquisa. Não obstante, foram consultadas outras edições, em especial a de D. Christenson (Amphitruo, 2000) e as versões para o português de Carlos Alberto Louro Fonseca (Anfitrião, 1993) e de Jaime Bruna (Anfitrião, 1978), principalmente para solucionarmos certas dúvidas de tradução e interpretação.

\subsection{Perspectivas Teóricas}

Da perspectiva comparativista, se o cotejo aqui pretendido é entre a peça plautina e sua fonte, notamos que, na recriação dramatúrgica do escritor latino, há diversas semelhanças e divergências em relação ao mito original. Antes, porém, precisamos expor os pressupostos que utilizaremos para analisar as relações que ela estabelece com seu texto base. Importa destacar ainda que essa mesma linha teórica nos guiará também na análise dos elementos intertextuais, tanto de semelhança quanto de diferença, entre $\mathrm{O}$ Homem Duplicado e o escrito de Plauto.

A colaboração de Gérard Genette em seu livro Palimpsestos (2006) é fundamental, dada a importância que o estudo adquire no âmbito aqui pretendido. Nas suas

\footnotetext{
${ }^{34}$ Quanto ao vocábulo arúspices, encontramo-lo na tradução de Fonseca e a assumimos por se enquadrar perfeitamente no sentido do texto. Arúspice - também chamado de áuspice - é um sacerdote que, na antiga Roma, adivinhava o futuro mediante o exame das entranhas das vítimas.
} 
investigações, o teórico francês faz, inicialmente, uma correção em seus trabalhos: ele esclarece que o objeto da poética não é a arquitextualidade - como havia afirmado em sua Introdução ao Arquitexto (1986) -, mas a transtextualidade, ou a transcendência textual do texto, que ele define como "tudo que o coloca em relação, manifesta ou secreta, com outros textos" (GENETTE, 2006, p. 7). Não há, portanto, texto sem transcendência textual, além de outros tipos de relação intertextual. Afirma o teórico que "a transtextualidade ultrapassa e inclui a arquitextualidade (...)" (GENETTE, 2006, p. 7)

Genette afirma a existência de cinco tipos de relação transtextual: a intertextualidade, a paratextualidade, a metatextualidade, a arquitextualidade e a hipertextualidade. Segundo o mesmo teórico, a intertextualidade - primeiro tipo de relação transtextual, que possui seu paradigma terminológico dado por Julia Kristeva - define-se "como uma relação de copresença entre dois ou vários textos, isto é, essencialmente, e muito frequentemente, como presença efetiva de um texto em um outro. Sua forma mais explícita e mais literal é a prática tradicional da citação (...)” (GENETTE, 2006, p. 8). Dessa noção de intertextualidade, Genette aproxima os conceitos de plágio e de alusão, o plágio sendo um empréstimo não declarado e literal de outro texto e a alusão, um enunciado cuja compreensão plena supõe a percepção de uma relação entre um texto e outro ao qual necessariamente uma de suas inflexões remete.

Já a segunda noção de transtextualidade - a paratextualidade - é a relação menos explícita e mais distante que o texto propriamente dito mantém com o seu paratexto. Dentre os diversos elementos considerados pelo teórico francês como paratexto estão o título, o subtítulo, os intertítulos, prefácios, posfácios, advertências, prólogos, notas marginais, de rodapé, de fim de texto, epígrafes, ilustrações, errata, orelha, capa, e

\footnotetext{
(...) tantos outros tipos de sinais acessórios, autógrafos ou alógrafos, que fornecem ao texto um aparato (variável) e por vezes um comentário, oficial ou oficioso, do qual o leitor, o mais purista e o menos vocacionado à erudição externa, nem sempre pode dispor tão facilmente como desejaria e pretende. (GENETTE, 2006, p. 9-10)
}

A terceira proposição transtextual reconhecida por Genette é a metatextualidade, ou seja, a relação de comentário que une um texto a outro de que ele fala, sem necessariamente citá-lo e até mesmo sem nomeá-lo. Nessa citação há uma interseção de informações e conceitos de uma mesma área ou de uma mesma corrente do conhecimento, que desempenha uma função crítica. Segundo o autor, tal função faz com que sua natureza e estatuto sejam objetos de estudo da meta-metatextualidade (a crítica literária). 
A quinta proposição transtextual (Genette deixa, propositalmente, a quarta proposição para discorrer por último) é a arquitextualidade, que ele considera a mais abstrata e implícita. Trata-se de uma relação completamente silenciosa, muda, que articula uma menção paratextual de pertencimento taxionômico. Fazem parte desse tipo de menção os títulos como poesias, ensaios e referências infratitulares, tais como romance, narrativa, poemas que acompanham os títulos na capa. Todavia, nenhum texto tem a obrigação de indicar sua qualidade genética, ou seja, o seu pertencimento de gênero. Tanto que o teórico dirá que pode o leitor, o crítico ou o público recusar a indicação paratextual que uma obra carrega, sem que isso diminua sua importância. A percepção genérica orienta e até mesmo determina a expectativa do leitor em relação à recepção da obra.

O último tipo de transtextualidade é a hipertextualidade, a matéria geral de que tratará o livro do teórico, definida como "toda relação que une um texto B (que chamarei hipertexto) a um texto anterior A (que, naturalmente, chamarei hipotexto) do qual ele brota, de uma forma que não é a do comentário" (GENETTE, 2006, p. 12). Aqui, a noção proposta por Genette é a de um texto derivado de outro preexistente. Essa derivação pode se dar tanto por ordem descritiva e intelectual - em que um texto fala do outro - quanto de outra ordem -por exemplo, quando um texto B não fala de $\mathrm{A}$, mas não poderia existir sem ele. O autor, então, distinguirá nessa relação hipertextual duas formas pelas quais ela acontece: a relação simples ou direta e a relação por imitação.

A relação hipertextual simples ou direta se dá quando a ação de uma narrativa é transportada de um contexto para o outro sem sofrer uma grande alteração. Um exemplo dessa relação seria a transposição que Joyce faz da Grécia, tal como foi desenhada por Homero na Odisseia, para a Dublin do século XX, em seu Ulisses.

Já a relação hipertextual por imitação supõe que o leitor identifique, no enunciado B, uma certa maneira de ser do texto A. Depois, é preciso que esse segundo texto exprima da mesma maneira (no mesmo estilo) uma outra opinião, corrente ou não. Bakhtin chama a esse processo de estilização. Um exemplo seriam os provérbios "o amor é cego" e "dizem por aí”, magistralmente fundidos para realizarem essa relação imitativa: “(...) o amor, que dizem ser cego, (...)." (SARAMAGO, EC, 1996b, p. 154). A intencionalidade do discurso de Saramago é criar provérbios contrários aos popularmente conhecidos, recuperando da tradição alguns deles e transformando-os de modo a negar o sentido inicial. Assim, expressando pelo mesmo estilo (provérbio), o citado trecho do romance de Saramago traz em seu bojo uma outra opinião, destoante do conceito comum, irônico ao negar sua forma 
primeira. Completa o teórico que essa segunda operação é mais complexa e mais indireta do que a primeira.

Por fim, é importante notar que, embora em Palimpsestos Genette fixe seus estudos na hipertextualidade, há uma ressalva fundamental feita por ele: os cinco tipos de transtextualidade não devem ser considerados como classes estanques. Ao contrário, entre eles há comunicações numerosas e decisivas. Sendo assim, a arquitextualidade genérica, por exemplo, constitui-se quase sempre mediante a imitação da hipertextualidade; o domínio arquitextual de uma obra é frequentemente declarado por meio de índices paratextuais, os quais são amostras do metatexto (como na afirmação "este livro é um romance"), e o paratexto, prefacial ou outro, contém muitas outras formas de comentário.

No sétimo capítulo de seu livro, o teórico da literatura precisará melhor seu objeto de estudo, construindo um quadro geral das práticas hipertextuais. Como nosso escopo é o de tomar os conceitos genettianos unicamente como orientação geral para o estudo do Amphitruo e de O Homem Duplicado, sintetizaremos apenas os conceitos que dizem respeito a este corpus, somados a dois outros que, mesmo sem serem explorados por Genette, são acrescentados às suas pesquisas, os quais também serão úteis à nossa análise. Dessa forma, nos valeremos dos conceitos de acréscimo e supressão propostos por Genette, somando a eles os de inversão e deslocamento buscados em outros autores.

Ao tratar da transposição - para Genette a mais rica das categorias em procedimentos técnicos e investimentos literários - o teórico afirma que esta contém em seu bojo duas operações de que necessitaremos adiante e que resumiremos a seguir: o acréscimo e supressão.

O primeiro processo de que trataremos aqui é o acréscimo ou amplificação. Apesar de Genette subdividir esse processo em três conceitos distintos, entenderemos aqui acréscimo como o processo por meio do qual o escritor amplia, em seu texto, algo em relação ao texto primeiro. A amplificação

\begin{abstract}
é um aumento gradual, por meios artísticos, do que é dado, por natureza, (...) é portanto, um meio de parcialidade, e isso tanto no domínio intelectual, como no domínio afectivo. (...) a função principal da amplificação é o aumento (vertical). A execução deste aumento (vertical) pode dar como resultado um alargamento (horizontal) da expressão. Portanto, o que verticalmente se aumenta, é a matéria do discurso ou um pensamento, que serve para o seu tratamento, facto esse que geralmente acarreta um alargamento da formulação linguística (LAUSBERG, 1972, p. 106).
\end{abstract}

Por seu turno, a supressão é o processo oposto ao do acréscimo, já que, ao invés de ampliar, suprimem-se maciçamente do texto original trechos, cenas ou períodos narrativos 
inteiros. Esse mecanismo processa uma economia na matéria narrativa. Nas palavras de Lausberg, o mecanismo omite “(...) pensamentos, em princípio necessários para a finalidade da comunicação. (...) mas também podem tornar-se num ideal de estilo (...).” (1972, p. 242).

Somados a esses dois processos amplamente explorados por Genette, temos ainda a inversão e o deslocamento, conceitos que não são alvo dos estudos teóricos do crítico francês, mas são de grande riqueza para o cotejo que pretendemos realizar na análise do procedimento elaborativo tanto de Saramago quanto de Plauto. Assim, a inversão, segundo define Bouché (1974, p. 52), se caracteriza pelo rebaixamento ou dessacralização que o texto $\mathrm{B}$ imprime ao texto $\mathrm{A}$. Esse processo, que pode ser tocante às personagens, às ações ou, também, às características das personagens, consiste no "enfraquecimento da intensidade do efeito (...)" (LAUSBERG, 1974, p. 102) e permite que o efeito de rebaixamento, caracterizador da paródia (cf. KOTHE, 1980, p. 98), se estabeleça.

Por fim, o deslocamento, para Bouché (1974, p. 52-53), consiste em uma espécie de transferência de qualquer tipo, ou, como diz Lausberg, em "uma mudança de lugar de, pelo menos, um elemento (1972, p. 102). Segundo a visão dos autores citados, pode haver um deslocamento de qualidade de uma personagem a outra, a transferência de autoria, de um período, época, tempo, local, provocando, certas vezes, uma inadequação.

Cumpre fazer uma ressalva antes de seguir adiante. Embora saibamos que o uso da teoria não deve aprisionar o objeto estudado, as sugestões de Gérard Genette e dos demais teóricos aqui referidos servem de guia unicamente para abrir o caminho à nossa pesquisa, para oferecer-nos pistas e nos ajudar a manter a máxima objetividade possível.

\subsubsection{Acréscimos}

O primeiro elemento intertextual no texto plautino se nos revela pela presença de acréscimos que contribuirão para enriquecer o texto que relê o outro. A peça plautina não apresenta muitos acréscimos devido à redução para um dia da narrativa mítica de Anfitrião; mesmo assim, ela apresentará novidades a seu protótipo, renovando a trama já conhecida.

Um primeiro acréscimo em relação ao modelo mitológico é a personagem Brômia, a fiel escrava de Anfitrião, cuja presença funciona como contraponto de Sósia, sendo este escravo de Anfitrião e aquela, escrava de Alcmena. 
Um segundo elemento acrescido à peça plautina é o engravidamento de Alcmena por Anfitrião. Na peça, o herói a deixa grávida antes de partir para a guerra, diferentemente do que ocorre na narrativa mítica, pois nesta Alcmena só se deita com seu esposo após a vingança da honra de seu pai.

Plauto acresce esse elemento para encontrar a coerência interna que sua peça exige. No protótipo, Alcmena não poderia estar grávida porque era virgem e só se entregaria ao esposo se este vencesse os inimigos de seu pai. Já na peça é necessário que ela esteja grávida para que possa aceitar Júpiter em seu leito sem contestações e que Anfitrião desconfie apenas da traição, e não da gravidez. Se assim não fosse, o conflito da peça estaria localizado primeiramente na gravidez; em segundo, no tempo decorrente entre a fecundação e o nascimento, pois se, conforme diz Aristóteles - e Plauto segue essa prescrição - o tempo na tragédia não poderia ultrapassar um dia, como Plauto faria para justificar a fecundação e o nascimento de Hércules?

A explicação se encontra essencialmente na consumação do casamento entre Anfitrião e Alcmena antes de ele partir para a guerra, o que justifica a gravidez de Alcmena, o nascimento do filho de Júpiter e, principalmente, organiza a coerência interna, mantendo a prescrição aristotélica de um dia para o desenvolvimento do enredo das peças trágicas.

Na peça de Plauto, os acréscimos se resumem à gravidez de Alcmena e à figura de Brômia, o que nos permite perceber que a tradição erigida pelo protótipo plautino foi mantida. Entretanto, se os acréscimos se resumem a dois, as supressões, ao contrário, são várias e permitem notar a novidade instaurada pelo autor, acrescentando outros valores ao que era genuinamente grego e, também, religioso.

\subsubsection{Supressões}

Quanto às supressões realizadas em relação ao protótipo mítico, há, como já comentamos, a relacionada ao tempo, cuja duração, na peça, é de apenas 24 horas, de acordo com o que reza a Poética aristotélica. Com isso, é suprimido o assassinato do sogro de Anfitrião e toda a história que se liga a esse fato. Plauto inicia a peça não com o casamento ou o encontro de Alcmena e Anfitrião, mas com uma personagem, no argumento, narrando a batalha de Anfitrião contra os Teléboas - que está por ser vencida pelo general tebano - e a atitude de Júpiter enquanto a batalha está a acontecer. Tal 
supressão produz um novo cenário dentro da narrativa mítica, além de estabelecer um ponto de leitura que insere um novo dado, por meio de supressões, dentro do tradicional.

Essa supressão temporal, considerada a principal de todo o texto plautino, servirá de base para todas as outras supressões realizadas pelo texto. Ao suprimir o motivo da morte do sogro de Anfitrião e a causa da guerra que ele travará com os Teleboas, a peça elimina diversas personagens de grande importância na narrativa mítica, tais como Eléctrion pai de Alcmena, o rei Creonte, Alceu e Astidameia pais de Anfitrião, o rei Pélops, o rei Estênelo tio de Anfitrião, o rei Ergino, Apolo, Hera, Tirésias, o adivinho, e Perseu.

Cada uma delas é suprimida por um ou outro motivo que a própria trama nos revela. Eléctrion, o rei Creonte, Alceu e Astidameia, o rei Pélops, o rei Estênelo, o rei Ergino e Perseu são suprimidos da peça plautina devido à extensão de tempo da ação. Ou seja, se a ação ocorre apenas no dia em que Júpiter dorme com Alcmena, é desnecessária a presença e até mesmo a citação das personagens que compõem a família dos dois humanos ou as personagens que antecedem a guerra de Anfitrião com os Teleboas.

Já Apolo, Hera e Tirésias são suprimidos por outros motivos que servem para ancorar literariamente o enredo e permitem a sua coerência interna. Assim, Tirésias é suprimido por ser uma personagem oracular que poderia, se estivesse na peça, revelar a origem de toda a confusão. Mesmo com essa supressão, o nome de Tirésias aparece no desfecho, em uma fala de Anfitrião. Inicialmente essa referência não tem explicação, mas depois podemos ver que ela serve para resgatar o modelo do qual Plauto se valeu:

ANFITRIÃO: Cumprirei os teus pedidos e lhe peço que, em troca, continues a cumprir suas promessas. Irei para dentro, acompanhar minha esposa; o velho Tirésias pode ir para sua vida! Porém espectadores, em favor a Júpiter supremo, força! Saudai-o com palmas (PLAUTE, 1970, p. 75) ${ }^{35}$.

As palavras sobre o adivinho instauram uma inadequação que, segundo Bouché (1974, p. 52-3), pode gerar o ridículo. Entretanto, cremos que a personagem que aqui aparece fora de contexto parece constituir um caso de deslocamento. Esse deslocamento, mais que gerar o ridículo, promove o intercâmbio entre o paradigma e sua recriação literária. A figura de Tirésias resgata, no novo, a figura e a influência de sua base, promovendo um encontro entre os dois textos no mesmo discurso.

\footnotetext{
${ }^{35}$ No original: Faciam ita ut iubes et te oro, promissa ut serues tua. / Ibo ad uxorem intro: missum facio Teresian senem. / Nunc, spectatores, Iouis summi causa clare paludite.
} 
Como decorrência da supressão dos episódios citados, a narrativa obriga que outras personagens sejam suprimidas, também em favor da economia artística. Justifica-se, assim, a eliminação da figura de Apolo; em seu lugar, temos a manifestação suprema de Júpiter Magno, capaz inclusive de parar o sol e a lua, metonímias do dia e da noite ${ }^{36}$.

Por fim, desaparece Hera, a terrível e ciumenta esposa de Júpiter. Na narrativa mítica, uma das versões narra que é a própria deusa quem coloca duas serpentes nos filhos de Alcmena, com o intuito de eliminar o filho de Júpiter com a amante terrena. Na peça de Plauto, as serpentes surgem do céu, mas não sabemos quem as envia:

BRÔMIA: Já vais ficar ainda mais admirado. Pois aconteceu que, no berço, surgem do alto do teto e se lançam em voo para o mesmo duas serpentes com cristas enormes. ANFITRIÃO: Ai de mim.

BRÔMIA: não tenha medo. Neste entremeio de tempo, as serpentes olharam para todas as pessoas ao redor. Assim que viram os meninos, elas se atiraram correndo em direção ao berço. Eu estava a arrastar, a levar o berço sempre mais para longe, temendo pelas crianças e por mim mesma; e as serpentes sempre a nos perseguir cada vez mais (PLAUTE, 1970, p. 73-74, grifos nossos) ${ }^{37}$

Por meio desse acontecimento insólito - não sabermos quem envia as cobras ao berço das crianças -, Plauto suprime a ira da esposa de Júpiter, de forma a manter o desenlace e não comprometer o desenvolvimento da trama.

Paralelamente a essa supressão, também a ira de Anfitrião é suprimida. Recordemos que, após saber que sua mulher o havia traído, a narrativa mítica reza que Anfitrião colocou a jovem numa enorme pira e ateou fogo, mas teve a labareda detida pela intervenção de Júpiter, que envia uma chuva torrencial e apaga a fogueira. Em Plauto, a ira de Anfitrião é substituída pelo seu sofrimento por não saber se sua mulher o traíra ou não; essa marca do sofrimento é típica do teatro plautino. Como nos refere Citroni:

(...) Plauto demonstra construir de preferência as suas comédias seleccionando livremente e cruzando entre si diferentes fios dramáticos, investindo as personagens de funções diferentes ao longo dos diversos momentos da acção (...) para depois tudo simplificar no desenlace final (2006, p. 111).

\footnotetext{
${ }^{36}$ Tema que se aproxima da narrativa bíblica. Cf. o Livro de JOSUÉ 10, 43-43 In: A Bíblia de Jerusalém, 1991, p. 362-3.

${ }^{37}$ No original: BROMIA: Magis iam faxo mira dices. Postquam in cunas conditust, / Deuolant angues iubat deorsum in impluuium duo / maximi; continuo extollunt ambo capita.

AMPHITRUO: Ei mihi!

BROMIA: Ne paue. Sed angues oculis omnis circumuisere. / Postquam pueros conspicati, pergunti ad cunas citi. / Ego cunas recessim rursum uorsum trahere et ducere, / Metuens pueris, mihi formidans, tantoque angues acrius / persequi. Postquam compexit anguis ille alter puer, / itus e cunis exilit, facit recta in angui inpetum, / Alterum altera prehendit eos manu perniciter.
} 
Em Plauto, o cômico é tangenciado pelo trágico, possibilitando que o interesse dramático recaia "antes sobre a energia vital daqueles que, perante as dificuldades, inventam planos e estratagemas" (CITRONI, 2006, p. 111).

Quanto ao espaço, enquanto na peça a ação ocorre apenas dentro e nos arredores da casa de Anfitrião, na cidade de Tebas, no mito os acontecimentos ocorrem em Tebas e em outras cidades, como Micenas, Tafos e Argos. No caso de Plauto, a supressão se justifica pela adequação ao espaço do palco e, também, para concordar com a supressão dos acontecimentos anteriores à noite de Júpiter com Alcmena. Todos os casos de supressão são necessários, pois não há como intercambiar, no palco, diversos espaços; além disso, não há como, em um dia, percorrer os diversos e afastados espaços que aparecem no mito.

\subsubsection{Inversões}

A inversão, processo que se caracteriza pelo rebaixamento ou dessacralização que um texto imprime ao protótipo, acontece de duas formas diferentes em Plauto. As inversões podem acontecer ora na estrutura, ora no enredo da peça, realizando um perfeito casamento entre forma e conteúdo.

Como já afirmamos, um grande elemento que norteia a composição da peça plautina é a Poética aristotélica. Mas o exame dos mecanismos intertextuais da peça do escritor latino nos revela que ora sua leitura da Poética se dá obedecendo a ela, ora subvertendo-a.

Segundo a Poética do Estagirita, a epopeia e a tragédia deveriam se deter em pessoas que realizam ações acima da média, ou seja, as ações vividas pelas personagens seriam tão complicadas ou sofridas que estariam em um patamar mais elevado que a maioria das pessoas, seja por seus sofrimentos, seja por suas conquistas. A tragédia e a epopeia apresentavam sempre heróis figurando como semideuses, tanto pelas atitudes quanto pelo relacionamento e postura para com os deuses - afinal, os heróis gregos das tragédias e epopeias enfrentavam, literalmente, a vontade e os desígnios divinos.

Entretanto, ao construir suas personagens, Plauto inverte essa prescrição aristotélica. Em Anfitrião, Júpiter e Mercúrio são os deuses, as personagens acima da média. Porém, Alcmena, um ser humano, é a escolhida pelo autor como personagem acima da média.

Como explicita Citroni: 
(...) as personagens plautinas pretendem ser, mesmo à custa da verossimilhança $\mathrm{e}$ da coerência da acção dramática, maiores do que a vida, verdadeiros gigantes cómicos, cuja existência se esgota em cena, fiéis à sua natureza fictícia até às últimas consequências. (2006, p. 112)

Por ter uma alma trágica - típica das personagens elevadas - Alcmena demonstra sua força ao enfrentar o marido, a sociedade da época - representada por aqueles que atuam na peça como personagens secundárias - que a veem como traidora - e até mesmo os deuses, que a fizeram cometer uma traição sem saber que a cometia. Sua atitude é a de uma personagem trágica, que não se resigna com seu destino. Alcmena representa um “(...) papel ativo desempenhado na comédia plautina pelas mulheres, sobretudo as esposas (pense-se nas enérgicas matronas, que contrariam triunfalmente os inconfessáveis desígnios dos senes) (...)”. (CITRONI, 2006, p. 118-19).

Enquanto Alcmena se assemelha a uma personagem heróica, Júpiter e Mercúrio são rebaixados de suas posições celestes a seres com vontades carnais, raivosos, explosivos e mesquinhos. Júpiter é, apesar de celeste, um deus com instintos humanos primitivos: birrento, manhoso e covarde. Já Mercúrio é fanfarrão, preguiçoso e maldoso.

Essa inversão de atitudes realizada por Plauto, tendo como elemento parodiador os postulados aristotélicos, serve para instaurar e propiciar o riso em sua peça.

Outra prescrição subvertida pelo texto plautino diz respeito à dessacralização da religião. A função da tragédia é a de demonstrar o poder máximo da moira em face dos desígnios humanos e sobrepor o plano celeste ao humano. O texto de Plauto, no entanto, inverte a noção religiosa que a tragédia geralmente apresenta. $\mathrm{O}$ escritor latino propõe uma nova configuração da questão religiosa ao pôr uma mulher (Alcmena) - que, por natureza, é menor - a desafiar deuses e heróis para manter incólume sua honra de esposa.

Se, em Roma, a religião e o costume tinham institucionalizado um espaço em que as regras de convivência social pareciam estar próximas da suspensão ou inversão,

(...) durante as festas de Saturno, a cidade vivia dias de grande excitação, nos quais era licito dar largas a todas as pulsões que a vida diária reprimia. Um pouco como no nosso Carnaval, nesses dias, os Romanos entregavam-se ao jogo e ao devaneio, permitiam-se certas liberdades e aceitavam-se diversos tipos de desregramentos: excessos alimentares, embriaguez, vulgaridades, linguagem obscena e, inclusivamente, brincadeiras agressivas. Tudo aquilo que durante o ano se recalcava e reprimia triunfava através de uma desordem festiva na "liberdade de Dezembro". A subversão mais assinalável era o facto de ser "toda e qualquer autorização" aos escravos, graças à qual tinham uma oportunidade de serem iguais a seus amos, podiam falar com eles sem travões, sentar-se à mesa com eles. (CITRONI, 2006, p. 120)

A mulher devia a seu esposo respeito e aceitação. Ao desobedecer-lhe - sendo que essa obediência era uma prescrição religiosa também -, Alcmena parece assumir essa 
função carnavalesca para sua atitude, um fato aceito plenamente dentro da verossimilhança interna da peça. Essa aceitação inverte a proposição do mito - que foi produzido dentro da realidade religiosa - e inverte a prescrição seguida na época.

Como afirmaCitroni, essa experiência

(...) para a qual apela o teatro de Plauto pode ser a do modelo cultural "saturnalício-carnavalesco". O espectador era convidado a sentir que estava perante o mundo invertido das festas de fim de ano, em que os escravos se tornavam heróis em que a alegria e o prazer eram ilimitados, e em que se subvertia todo o tipo de autoridade (pais e patrões). Todavia, o final da comédia, que é o momento em que tudo se recompõe através de um bom casamento ou de um perdão colectivo, é o momento em que já se anuncia o fim da transgressão e a reentrada nos esquemas "burgueses". O próprio espectador já sabia que iria ser o desenlace, mesmo enquanto apreciava os atrevimentos e as aldrabices do seruus. (2006, p. 120)

Orientando-nos pelo pensamento bakhtiniano, podemos dizer que o que Plauto realiza é a carnavalização do elemento religioso em suas peças (cf. BAKHTIN, 1998, p. 123).

Lida como um todo, a peça de Plauto apresenta três grandes transgressões ao inverter as personagens da narrativa mítica.

A primeira grande inversão reside na personagem Blefarão. Se, na narrativa mítica, era Tirésias o juiz da contenda entre Anfitrião e Alcmena, na peça, será Blefarão quem terá essa função. Ao propor a inversão de um oráculo (Tirésias) em uma pessoa sem poderes mágicos ou divinatórios (Blefarão), Plauto mantém sua peça coerente internamente e renova a narrativa mítica. Em verdade, Blefarão é a figura de Tirésias carnavalizada ${ }^{38}$, ou seja, ele é rebaixado por meio desse recurso da carnavalização.

Quanto às personagens extraordinariamente "acima do comum dos mortais", os deuses, deusas e heróis, a trama de Plauto, como já dissemos, as inverte, tornando-as seres com atitudes mortais, com suas perspectivas divinas excluídas e suas características nobres dessacralizadas. É o que ocorre com as personagens Júpiter e Anfitrião - um deus e um herói - que são apresentadas realizando artimanhas e estratagemas comuns a simples

\footnotetext{
${ }^{38}$ Entendemos carnavalização como a penetração de elementos carnavalescos na visão oficial. Esses elementos são diversos, como o inacabamento, a visualização da dualidade de percepção do mundo e o princípio da vida material e corporal, ou seja, a "transferência ao plano material e corporal, o da terra e do corpo na sua indissolúvel unidade de tudo que é elevado, espiritual, ideal e abstrato" (BAKHTIN, 1998, p. 17). Dentro dessa concepção de mundo, o medo é sempre vencido pelo riso, graças à ambivalência de suas imagens. Assim, a literatura carnavalizada, tal qual Bakhtin a define em seu Problemas da poética de Dostoievski, é a "literatura que, direta ou indiretamente, através de diversos elos mediadores, sofre a influência de diferentes modalidades do folclore carnavalesco" (BAKHTIN, 1998, p. 107).
} 
mortais, mas não a figuras divinas. O próprio Zeus é apresentado como o mais comum dos mortais, com os mesmos desejos e fraquezas dos homens.

Já Mercúrio é invertido de porta-voz de Júpiter a pombo-correio na trama. Retomemos um trecho da peça para ilustrar como essa sutil inversão se efetua:

\begin{abstract}
Agora Júpiter ordenou que eu viesse aqui falar com vocês, para que fiscais fossem ter com os espectadores, de cadeira em cadeira, por todo o teatro. Se eles virem partidários enviados contra este espetáculo, que a pessoa tenha como penhor na plateia a toga tomada. Os que ficam arrebanhando palmas, seja para os atores, seja para algum artista - quer, por meio de escritos, quer os que arrebanham pessoalmente, quer por um intermediário -; quer ainda aquele a quem os edis tenham favorecido de forma incorreta; Júpiter ordenou que fosse aplicada exatamente a mesma lei, que seria aplicada caso um magistrado houvesse praticado o crime de corrupção eleitoral. Disse ele que vocês são vencedores por viver com virtude, e não com ambição ou perfídia: por que seria mais branda a mesma lei para um ator que para um homem de cunho elevado? Convém arrecadar votos por meio da virtude, não por meio de partidarismo. Quem age corretamente tem sempre partidários o suficiente, se os que administram o negócio têm palavra. Júpiter me deu ainda como incumbência também isto: que eles se tornem fiscais no interesse dos atores, para que, se alguém tiver enviado pessoas encarregadas de aplaudir, ou se, da outra parte, alguém tiver um desempenho inferior ao que agradaria, que retalhem as vestes $e$ a pele dele. Não se admirem vocês que Júpiter agora se preocupe com os atores. Não se admirem: o próprio Júpiter haverá de atuar nesta comédia (PLAUTE, 1970, p. 13-14, grifos nossos) ${ }^{39}$.
\end{abstract}

Em lugar de apenas cumprir sua função de mensageiro dos deuses - pois na mitologia romana Mercúrio era o responsável por levar aos homens e a outros deuses as grandes decisões tomadas por Júpiter, ou ainda, na direção inversa, era aquele que relatava ao grandioso deus dos deuses os acontecimentos ocorridos no mundo dos mortais -, na peça de Plauto, Mercúrio envolve-se em discussões e rusgas de foro humano, incompatíveis com seu estatuto divino. Sua personificação de deus da eloquência e da inteligência é invertida na peça para em um mero empregado de recados, um porteiro, ocorrendo a dessacralização de suas funções divinas. Mercúrio passa a ser um mero observador e cumpridor de ordens que, ao mesmo tempo que ameaça, é ameaçado por seu público. Esse fato é levado às últimas consequências quando o deus assume as feições de Sósia e sofre um rebaixamento, passando de deus a escravo.

\footnotetext{
${ }^{39}$ No original: Nunc hoc me orare a uobis iussit Iuppiter, / ut conquistores singula in subsellia / eant per totam caueam spectatoribus. / si cui fauitores delegatos uiderint, / ut is in cauea pignus capiantur togae. / siue qui ambissent palmam histrionibus / siue cuiquam artifici, seu per scriptas litteras / siue qui ipse ambisset seu per internuntium - -; / siue adeo aediles perfidiose cui duint; / sirempse legem iussit esse Iuppiter, / quasi magistratum sibi alteriue ambiuerit. / uirtute dixit uos uictores uiuere, / non ambitione neque perfidia; qui minus / eadem histrioni sit lex quae summo uiro? / virtute ambire oportet, non fauitoribus. / sat habet fauitorum semper qui recte facit, / si illis fides est quibus est ea res in manu. / hoc quoque etiam mihi / in mandatis dedit, / ut conquistores fierent histrionibus. / qui sibi mandasset delegati ut plauderent / quiue quo placeret alter fecisset minus, / eius ornamenta et corium uti conciderent. / mirari nolim uos, quapropter Iuppiter / nunc histriones curet. ne miremini: / ipse hanc acturust Iuppiter comoediam.
} 
Um terceiro elemento desse processo de inversão está na fala empregada por Mercúrio. A personagem, por se tratar de um deus, deveria ter uma linguagem mais cuidada, tal qual a linguagem forense empregada pela mesma no prólogo. No entanto, ele passa a usar uma linguagem prepotente, ambígua e, às vezes, até mesmo chula. Exemplo dessa linguagem são os termos velhaco (uerbero), patife (furcifex) e carniceiro (carnufex), que Mercúrio usa para se referir a Sósia. Essa inversão da linguagem aparece também nas ameaças que o deus dirige ao escravo: "você vai ser carregado, não andará com suas próprias pernas, se eu pegar o meu cacete" (PLAUTE, 1970, p. 29) ${ }^{40}$.

Enfim, podemos constatar que as situações nas quais temos uma inversão relacionada com a figura dos deuses ou heróis são geralmente pautadas no processo de rebaixamento. Assim, inversão e rebaixamento são os dois elementos utilizados por Plauto para instaurar a "repetição com diferença" em sua peça.

\subsubsection{Deslocamentos}

Tendo já exposto nossos pressupostos teóricos, partiremos para o exame da elaboração hipertextual que Plauto realiza em relação ao paradigma mitológico. Conforme o próprio escritor, aquilo que irá ser apresentado é "uma velha história antiga renovada" (PLAUTE, 1970, p. 15) $)^{41}$.

Dessa forma, a subdivisão do texto plautino é um primeiro elemento novo instalado no antigo. Essa divisão em cenas e atos se constitui como deslocamento e se localiza na estrutura de sua obra. A peça se divide em sete partes organizadas da seguinte forma: dois argumentos que explicam e introduzem a obra, um prólogo e cinco atos assim subdivididos: o primeiro com três cenas, o segundo com duas, o terceiro com seis e um fragmento que segue uma lacuna que não sabemos de quantas páginas seria, o quarto com uma cena e o quinto com duas, perfazendo um total de dezoito partes.

Esse deslocamento estrutural aponta para a supressão do tempo, justificada pela prescrição aristotélica de que uma peça precisa durar um dia para alcançar uma melhor economia literária. Por causa disso, a peça plautina perfaz um tempo de 24 horas,

\footnotetext{
${ }^{40} \mathrm{O}$ ato de pegar o cacete é muito comum nas comédias de Plauto e sempre pode ser compreendido em seu sentido obsceno. No original: Aufere, nona abibis, si ego fustem sumpsero.

${ }^{41}$ No original: Veterem atque antiquam rem nouam ad uos proferam.
} 
seguindo, assim, a base teórica que a ampara - e a toda a escrita da época -, a Poética aristotélica. Ao comentar sobre a teoria dos gêneros, Aristóteles ressalta que toda peça trágica tem a duração de um dia (ARISTÓTELES, 1992, p. 12). Respeitando o espaço de tempo previsto pelo Estagirita, Plauto reduz sua peça a um dia, deixando implícitos os acontecimentos anteriores à noite que Júpiter passa com Alcmena.

Quando a peça se inicia, Júpiter está no quarto de Anfitrião, entregue ao prazer de uma noite de amor. Para vencer a renitência da virtude de Alcmena e para facilitar o acesso ao leito proibido, o deus valeu-se do disfarce e vestiu a pele do marido ausente. Eis constituído, por artes olímpicas, o primeiro par de simillimi. Um segundo par a ele se segue: para dar também credibilidade a Mercúrio, companheiro do deus, é-lhe atribuído o exterior de Sósia, servo e companheiro de Anfitrião.

Tal deslocamento temporal condensa ao máximo a trama, permitindo, nesse caso, que o elemento trágico se apresente junto ao cômico. Sua função é a de permitir que, dentro da economia da peça, tenhamos uma visão ampla de todo o contexto, sem fugir à prescrição aristotélica da unidade temporal (ação acontecendo em apenas um dia).

Outro deslocamento se dá quanto à questão do narrador. Enquanto o mito de Anfitrião possui um enunciador desconhecido, marcado principalmente pela oralidade, a peça plautina elege Mercúrio como seu narrador. Este narrador-personagem, no prólogo, dirige-se à plateia, à qual ele resume os antecedentes do mito:

Agora, vou dizer-lhes quem me mandou e ao que vim, e, ao mesmo tempo, revelar o meu nome. Estou aqui por ordem de Júpiter; o meu nome é Mercúrio. Foi meu pai que me enviou a este lugar, para lhes fazer um pedido, apesar de saber que uma palavra sua é uma ordem para vocês, pois não ignora que o respeitam e o temem. Mas, entre o certo e o duvidoso, mandou-me ele que lhes falasse com calma, em suma, com boas palavras. É que o Júpiter, que me mandou aqui, ter convosco, também morre de medo, mais que qualquer um de vocês: filho de mãe mortal e de pai de raça humana não é para admirar que ele o tenha! E eu, que sou filho de Júpiter, por contágio de meu pai, também não sou dos mais nervosos! (...) Agora exporei primeiro o motivo pelo qual vim falar aqui, depois contarei qual o argumento desta tragédia. Por que vocês contraem a face? Porque eu disse que será uma tragédia? Sou um deus, posso fazer uma reviravolta. Esta peça mesma, se quiserem, farei com que de tragédia seja comédia com todos os mesmos versos. Querem que seja assim ou não? Mas eu sou mesmo um tolo, como se não soubesse o que vocês querem, sendo eu um deus. Sei como é vosso pensamento acerca desse assunto. Vou mas é fazer com que seja uma comédia com uma pitada de trágico, pois não creio que seja justo fazer uma comédia de fio a pavio, quando nela intervêm reis e deuses. E então? Visto que aqui um escravo também toma parte, farei com que seja, de acordo com o que disse, uma tragicomédia. (...) Espectadores, muita atenção: vai valer a pena observar Júpiter e Mercúrio a fazerem comédia. (PLAUTE, 1970, p. 11-17, grifos nossos) $)^{42}$

\footnotetext{
42 Todas as traduções do texto latino são de nossa responsabilidade; nas exceções, indicaremos a procedência tradutória. Gostaríamos de frisar que não procuramos criar, em nossa tradução, qualquer desenho rítmico que
} 
O trecho, apesar de extenso, é importante, pois ilustra a tomada, por Mercúrio, do fio condutor da trama. $\mathrm{O}$ excesso de papéis de Mercúrio produz um acúmulo, uma vez que a personagem assume a função do coro, antecipando e até desvelando os fios do enredo, além de discorrer acerca do gênero poético no qual a peça se enquadra, bem como a função das personagens que tomam parte na ação, qual será a forma dos versos utilizados, qual o contexto teatral romano, entre outros temas correlatos.

A localização de um deus soberano acima do fatum permite que a trama que o mesmo conta vá se revelando ao espectador enquanto construção a cada linha. Isso porque

Graças e um conhecimento superior dos factos, e, por isso, a uma maior capacidade de decifrar as situações, o espectador deve observar o procedimento erróneo ou insensato das personagens, e antever o desenlace contraproducente que as espera; vê-as tropeçarem em todo tipo de equívocos, crédulas quando deveriam desconfiar e, por vezes, desconfiadas sem qualquer razão para tal. $\mathrm{O}$ espectador tira partido do facto de estar do lado dos que sabem, dos que enganam e dos que vencem, em vez de estar do lado do perdedor desprevenido. A sua privilegiada posição permite-lhe saborear cada um dos efeitos de uma requintada ironia cômica. (CITRONI, 2006, p. 120-21)

Esse fato se modela, por exemplo, pela citação a seguir:

Agora, para que vocês possam nos diferenciar mais facilmente, eu terei estas duas asinhas o tempo todo no chapéu; meu pai, então, por seu turno, terá um cordão dourado sob o chapéu; tal estigma Anfitrião não terá. Estes sinais ninguém dentre os familiares poderá ver, no entanto vocês [espectadores] os verão. ${ }^{43}$ (CITRONI, 2006, p. 16).

Ao revelar para o espectador a forma de identificar qual dos dois Sósias e qual dos dois Anfitriões é o verdadeiro, Mercúrio desvenda toda a origem do quiproquó que se dará na sequência e impede que o clímax se repita tal qual no mito original. Esse desvelamento

lembre o original, nem a divisão em linhas irregulares corresponde à pretensão de compor versos, pois nossa escrita só busca uma disposição que, facilitando a leitura, permita livrar a redação dos rigores da articulação da prosa em língua portuguesa. Assim, a presente tradução não pretende replicar a qualidade do original, mas apenas - sem ofender demais o português - oferecer ao leitor a quem o texto grego seja difícil ou inacessível uma transposição tanto quanto possível literal, que lhe permita acompanhar as anotações e que, juntamente com elas, lhe proporcione uma sugestão, fraca embora, do sabor exuberante da escrita plautina.

Assim, temos no original: Nunc cuius iussu uenio et quam ob rem uenerim, / Dicam simulque ipse eloquar nomen meum. / Iouis iussu uenio; nomen Mercuriost mihi. / Pater huc me misit ad uos oratum meus, / Tametsi pro imperiuo uobis quod dictum foret / Scibat facturos, quippe qui intellexerat / Vereri uos se et metuere, ita ut aequum est Iourem. / Verum profecto hoc petere me precário / a uobis iussit leniter dictis bonis. / Eterim illes cuius huc iussu uenio Iuppiter / non minus quam uostrum quiuis formidat malum: / Humana matre natus, humano patre / Mirare non est aequom, sibi si praetimet. (...) Nunc quam rem oratum huc ueni, primum proloquar; / Post argumentum huius eloquar tragoediae. / Quid contraxistis frontem? quia tragoediam / Dixi futuram hanc? deus sum, commutavero. / Eandem hanc, si vultis, faciam / ex tragoedia / comoedia ut sit omnibus isdem uorsibus. / Vtrum sit na non uotis? sed ergo stultior, / Quase nesciam.

${ }^{43}$ No original: nunc internosse ut nos possitis facilius, / ego has habebo / usque in petaso pinnulas; / tum meo patri autem torulus inerit aureus / sub petaso; / id signum Amphitruoni non erit. / ea signa Nemo / horum familiarium / uidere poterit, uerum uos uidebitis. 
torna o espectador participante especial da obra, tendo ele, junto com o deus-narrador, o domínio dos fatos que irão acontecer no decorrer da encenação.

Outro elemento presente no longo fragmento acima diz respeito ao gênero ao qual o texto plautino se filia. Ao iniciar a peça pelo clímax da narrativa mitológica, in medias res, característica fulcral das epopeias, Plauto obedece à prescrição aristotélica e acresce-lhe a sua genialidade de escritor, que renova a arte literária por meio de seu engenho. Ao lado desse caráter inovador da abertura, a peça de Plauto versará sobre fatos mitológicos e se utilizará de personagens consideradas por Aristóteles mais trágicas ou menos reais. Tal composição permite observar que a peça latina apresenta uma composição mista, que abrange os gêneros cômico, trágico e épico. Se, como já dissemos, Plauto escreveu sua peça segundo modelos gregos preexistentes, o dramaturgo latino mescla, em sua trama, cenas cômicas e sérias, o que lhe confere foros de tragicomédia. Não nos esqueçamos de que o Amphitruo plautino está classificado nos quadros da fabula rinthonica, uma forma de escrita que soma a sátira com enredos de tema mítico. Imbricar dois gêneros teatrais em uma síntese estrutural que mais tarde seria conhecida como tragicomédia pode ser percebido no preâmbulo da obra, quando Mercúrio diz:

(...) exporei os argumentos desta tragédia. Mas porque é que franziram a testa? Por ter falado de tragédia?... Sou um deus, posso dar uma reviravolta. Se quiserem transformo-a de tragédia em comédia sem mudar um único verso. (PLAUTE, 1970, p. 13)

Se, segundo Aristóteles, a tragédia lança ao palco, entre outros, deuses e heróis que, em sua trajetória, caracterizam-se por atitudes elevadas, acima da média, a peça plautina apresenta todos essas características concentradas na figura de Alcmena, a mulher sofredora que apenas abre a boca no final para desafiar os deuses e o marido em favor de sua honra intocável.

Já os deuses, que deveriam ter atitudes excelsas, realizam atos simplórios, mesquinhos, humanos - por assim dizer, uma forma de deslocamento também, dessa vez por meio do processo carnavalesco. São personagens que - segundo Aristóteles -, ao invés de terem atitudes sérias e influírem no trágico da obra, são cômicas. Soma-se a essa inversão a presença dos escravos - figuras cômicas por natureza - que travestem a trama e

\footnotetext{
${ }^{44}$ No original: (...) argumentum huius eloquar tragoediae. / Quid contraxistis frontem? Quia tragoediam / dixi futuram hanc? deus sum, commutavero. / Eandem hanc, si vultis, faciam / ex tragoedia / comoedia ut sit omnibus isdem uorsibus.
} 
instauram a novidade na peça plautina. A mescla de personagens de diferentes estatutos obriga, também, a uma mescla de gêneros.

A presença tanto de personagens elevadas (como reis e deuses), próprias da tragédia, quanto de personagens inferiores (como escravos), convenientes à comédia, impossibilita a opção por um ou outro gênero que não a tragicomédia, uma mescla dos dois gêneros, expressa pelas personagens criadas por Plauto.

Não é extraordinário que Plauto adote o tipo de personagem como critério distintivo entre comédia e tragédia, uma vez que Aristóteles, em sua Poética (1992, p. 18), já o havia mencionado.

É necessário ressaltar que essa diferenciação entre "personagens superiores" e "personagens abaixo da média" se refere às disposições éticas e escolhas manifestadas por essas personagens em ação e não à personalidade individual de cada uma na trama.

É dentro dessa inversão da prescrição aristotélica, na qual cada personagem expressa uma disposição contrária àquela ética prevista pelo Estagirita, que a adoção desse ponto de vista fica patente, inclusive no prólogo da peça. Temos a personagem Mercúrio apresentando-se à plateia e afirmando, diante dos romanos, que representará uma tragédia. Ao notar a contração dos rostos contrariados dos espectadores, o deus mensageiro corrigese sustentando que, sendo ele filho de Júpiter, tudo pode e, em um estalar de dedos, transformará a peça em uma tragicomédia.

Como a plateia ainda permanece contrariada, Mercúrio argumenta que, existindo deuses e reis na peça, não poderia ser de outra maneira. Ou seja, os deuses e reis são personagens elevadas e graves, daí a tragédia; elas geralmente ficam de fora da comédia. Já os escravos são, geralmente, personagens representativas das comédias. Como diz Citroni, os escravos eram usados em temas cômicos. Diz o teórico que "o escravo (que a sociedade agrária sujeitava a duras condições de domínio e de exploração) desafiava abertamente o amo e o terrível arsenal de punições que pendiam sobre a sua cabeça" (2006, p. 119). E o escravo era, ao desafiar o patrão, uma personagem que possibilitava diversas situações cômicas e que permitiriam a criação de quiproquós.

Alcmena, esposa dedicadíssima ao marido, é um reflexo da casta e severa matrona romana, personagem acima da média para compor uma peça. Já as figuras mais abaixo da média são os escravos, que, em Plauto, são substituídos por outras: Mercúrio, o servo divino, prepotente, brigão, linguarudo e sem-vergonha; e Sósia, o escravo terreno, fanfarrão, velhaco e obtuso. (cf. PLAUTE, 1970, p. 55) 
Plauto subverte, pois, os conceitos de comédia e tragédia, colocando personagens da efabulação trágica (deuses) em um enredo cômico, transgredindo assim a forma criada por seus antecessores. Assim, concordamos com Miner quando afirma que

o prólogo desta peça (versos 1 a 59) é tido, apropriadamente, como o lócus classicus da tragicomédia. Uma importante justificativa para esta denominação é o tratamento que Plauto dá tanto aos personagens divinos quanto aos personagens humanos na mesma peça, (...) (MINER, 1996, p. 59).

Plauto integra perfeitamente forma e conteúdo, criando um protótipo para uma posteridade que o visitará constantemente.

Os prólogos de Plauto são originais. Além de haver concebido um tipo de prólogo que a crítica considera didático, no qual se dava ao público um resumo da peça a ser apresentada, para melhor entendimento ele ainda acrescentava, por vezes, interessantes informações, tais como os protagonistas, quais atitudes e opiniões de cada personagem, dentre outras coisas.

Por fim, um último deslocamento presente no texto plautino se localiza no espaço. Apesar de a peça ser ambientada em uma cidade grega, há um processo evidente de romanização que, como comentamos, é chamado de acentum itallicum (PARATORE, 1980, p. 57). Os costumes romanos são evocados a todo o momento na peça (entretanto, grande parte desses recursos se perde na tradução). Um grande exemplo desse acentum seria a presença de deuses latinos coexistindo com divindades gregas.

No Amphitruo plautino temos, como exemplo, a questão da ação, que é suscetível de um deslocamento. Notamos que a ação da peça plautina ocorre na cidade grega de Tebas. Assim, a espacialidade manteve-se tal qual no mito original. Como já havia notado Citroni,

O ambiente da história da palliata é grego, como é grego o contexto social,
jurídico, institucional e económico em que decorre a acção das suas personagens.
Ao desenvolver uma tendência já testemunhada por Névio, Plauto polvilhou
sistematicamente as suas comédias com uma série de elementos
inconfundivelmente romanos que ora provinham da vida pública, ora da vida
privada: referência a instituições políticas ou militares magistraturas, nomes e
práticas da vida religiosa, localidades, determinações legais, costumes,
indumentária e outras ainda. (2006, p. 117)

Plauto recria esse ambiente grego em seu aspecto romano, “(...) mas, outras vezes, o pormenor romanizante é ampliado ao ponto de produzir passos com uma certa consistência, os quais suspendem momentaneamente a convenção grega da encenação. (CITRONI, 2006, p.117). Assim, as livres inserções de Plauto se tornam, para nós, deslocamentos que traduzem intenções significantes. 
Entretanto, como já havia apontado Cardoso (1995, p. 360), o espaço do paradigma é deslocado em diversos momentos da peça, criando ambientes que ela vai chamar de originais frente à convencionalidade. Assim, afirma Cardoso que

(...) apesar de basear-se em obras gregas, Plauto conseguiu ser bastante original impregnando suas peças de elementos romanos. É possível que essa romanização, considerada como uma das grandes inovações do teatro plautino e responsável pelo que se considerou mais tarde como a criação de um "teatro nacional" romano (...) (1991, p. 30).

Um exemplo desse deslocamento espaço-temporal está na referência de Sósia aos tresuiri nocturni que poderiam prendê-lo. Os tresuiri eram funcionários romanos; se a história se passa em Tebas, o deslocamento dessa personagem genuinamente latina para um espaço diferente do seu propiciará ao leitor um traço cômico, pois torna a cena inadequada. Como também observa Cardoso (1995, p. 360), Plauto ainda se vale de "estratégias tipicamente romanas" nas batalhas entre Tebanos e Teleboenses, tais como o envio de embaixadores para parlamentar, alinhamento de colunas, ritual de batalhas, etc., como vemos em "Dispusemos as legiões segundo nossa tática e costume" (PLAUTE, 1970, p. 18$)^{45}$.

Também emprega palavras latinas extraídas do jargão militar romano, como legati, castra legiones, imperatores etc., além das referências religiosas aos funerais e aos bonecos de cera, juntamente com a citação dos bacanais, que são práticas tipicamente latinas inseridas no contexto grego.

Outro elemento caracterizador dos deslocamentos na peça plautina são os nomes das personagens. Enquanto Anfitrião, Alcmena e Sósia mantêm os seus nomes gregos, os deuses são chamados e identificados por seus nomes latinos. Essa mescla entre nomes demonstra o deslocamento que os deuses sofrem e permitem que certa comicidade seja instaurada na peça.

Outro deslocamento se refere à gravidez de Alcmena. A matrona, no início da peça, já está grávida de Anfitrião, e este quer retornar da guerra para reencontrar sua esposa. Já no prólogo, Mercúrio dirá que "antes de ir para a guerra, o homem [Anfitrião] engravidou sua mulher." (PLAUTE, 1970, p. 15) ${ }^{46}$. Entretanto, a narrativa mítica diz que Alcmena só aceitaria se deitar com Anfitrião depois que este guerreasse com os Teleboas para vingar a morte de seu pai.

\footnotetext{
${ }^{45}$ No original: Nos nostras more nostro et modo instruximus / legiones".

${ }^{46}$ No original: Is prius quam hinc abiit iposemet in exercitum, / Grauidam Alcmenam.
} 
Mas, como a peça encena o dia de prazeres do deus dos deuses latino, o comediógrafo desloca o tempo de gravidez, mesmo porque sua peça deveria retratar apenas um dia, fato que exige a antecipação dessa gravidez para contemplar, na economia narrativa, todos os estágios da narrativa mítica, ou seja, a gravidez de Alcmena de seus dois filhos e a confusão que elas causam.

Por fim, o último elemento deslocado que verificamos na peça diz respeito à exaltação que Mercúrio faz de seu pai Júpiter. Ao se gabar de sua magistratura divina, o deus mensageiro perde esta pompa e se rebaixa, tal qual os homens soberbos. Esse rebaixamento, um processo de deslocamento da figura divina, possibilita que o dramaturgo transforme Mercúrio em um ser mesquinho. Esse processo de deslocamento de postura ocorre durante toda a peça. Sempre, ao exaltar sua generosidade e a de Júpiter, Mercúrio pensa se comparar aos outros deuses que aparecem em tragédias, gabando-se, pois, de suas benfeitorias; entretanto se diminui pelo ato soberbo e perde sua aura sacra

Tendo examinado os mecanismos intertextuais presentes na composição do Amphitruo, podemos chegar a algumas conclusões. É visível que, na peça, Plauto procedeu a uma economia seletiva de episódios míticos, obedecendo ao critério de produzir uma peça que seguisse as prescrições aristotélicas, mas cuja composição as subvertesse. Assim, o Amphytruo prova ser uma parte do "teatro vivo - [no qual] a criação e a produção de peças novas, de prestígio duradouro - requer elementos que sejam paradoxais, de difícil equilíbrio incendiário" (MINER, 1996, p. 58).

Em suma, por meio das reflexões que esse exercício nos permitiu, entendemos que a trama plautina, quando lida ao lado de seu paradigma, revela os processos de (re)criação do dramaturgo, explorando as concepções subjacentes a seu escrito e realizando uma transgressão na retórica da época.

Em vários aspectos do Amphitruo podemos depreender marcas de uma literatura que se alimenta ora de oposições extremas, ora de paráfrases, ora ainda de estilizações para com o texto reeescrito criticamente. Usando a base romana, Plauto criou uma comédia que sustenta o jogo entre tradição e novidade, permitindo uma nova visada sobre o antigo.

Além dessa relação com seu protótipo, podemos também acrescentar os mecanismos intertextuais que ajudam o escritor a compor a esfera de comicidade em Amphitruo, em que veremos posteriormente que a imagem de Anfitrião representa a imagem do homem de sua época, que perde sua estabilidade de ser quando tem seu eu dividido, mas que retorna ao centro quando há uma intervenção divina. 
O ser humano, na dramaturgia plautina, é uno, fechado, monolítico, completo como veremos adiante. Sua submissão à ordem divina "restaura" o caos instaurado no início da peça - quando Júpiter invade o espaço de Anfitrião e, posteriormente, Anfitrião invade o espaço de Júpiter. Veremos no capítulo quatro que o duplo cede lugar ao uno em Plauto para poder gerar essa ordem. E é essa ordem que permite que a imagem do sujeito da época seja una e indivisível.

Assim, temos um processo de escrita que torna a obra plautina uma provocação que, a cada dia, produz novos olhares e novos trabalhos para um mesmo e eterno problema: a espécie humana. 


\title{
CAPÍTULO III
}

\section{A ORDEM DO CAOS?: SARAMAGO E A LEITURA D'O ANFITRI $\tilde{A} O$ PLAUTINO}

\author{
Não essa que o pudor um dia larga, \\ Não essa que foi miragem e é negaça. \\ A porta derradeira é a que importa; \\ Caçador que porfia mata caça.
} (VIRGINDADE, In: PP, 1982, p. 38)

\subsection{Entre a ordem e o caos...}

Como já dissemos, todo texto se constrói em diálogo com outros textos. Esse diálogo se dá em diversos graus e seu estudo revela diversas facetas da criação literária. Adotando essa perspectiva dialógica e alinhando à postura de leitor a de crítico, constatamos que a literatura contemporânea vale-se, e muito, desse diálogo para pensar suas bases e a própria sociedade sobre a qual foi erigida. Tal é o caso do romance $O$ Homem Duplicado, do escritor português José Saramago, que se dedica a pensar a questão identitária do homem contemporâneo.

O objetivo que norteia este capítulo é o de estudar, novamente, os acréscimos, supressões, inversões e deslocamentos, voltando-nos agora à análise do texto saramaguiano em relação a seu protótipo latino. Para tanto, nos valeremos ainda das teorias formuladas por Genette (2009), Lausberg (1972) e Bouché (1974), aplicando-as à obra portuguesa.

Abramos um parêntese para ressaltar que, em O Homem Duplicado, a busca pelo outro e, consequentemente, pela identidade, o diluir do espaço e do tempo e a pequenez dos protagonistas apresentam características de uma fase particular do autor, que se coaduna com a postura do movimento pós-moderno. Essa fase, de sutil transformação na escrita saramaguiana, ocorre a partir da década de 90 e tem sido muito destacada pelos estudiosos dos romances do escritor português. Um exemplo está na afirmação que faz Beatriz Berrini em seu livro Ler Saramago: o romance:

De certa forma os romances parecem evoluir para um obscurecimento do tempo e do espaço; para um esquecimento da História e para um distanciamento de Portugal. O tempo passado apagou-se. Ainda persistem características portuguesas e da vida contemporânea, porém, as tramas giram em torno de certas ideias, o enredo configurando determinados problemas, que ultrapassam tais limitações. (...) Poderíamos até dizer que é o envolvimento afectivo com a pátria e com o agora que o leva a reflectir sobre problemas que não são apenas do seu 
país e de hoje. (...) Talvez pudéssemos sintetizar a evolução recente do romance de Saramago em poucas palavras, afinal: um certo desenraizamento em favor de um universalismo, de uma globalização - para usar um termo actual. O Evangelho segundo Jesus Cristo marca a transição (1998, p. 10-11).

Nesse período da sua produção, a alegoria e a atemporalidade percorrem os romances, os quais apresentam seres que, em sua pequenez, realizam grandes ações em suas minúsculas e desconhecidas vidas. São personagens em que pesam a ação e a reflexão dos seres humanos, que ocasionam desvios ficcionais daquilo que conhecemos como "verdadeiro" e completo. Na opinião de Maria Alzira Seixo, será precisamente "desta conjunção entre" ficção e realidade que Saramago irá

extrair uma noção de alteridade que (...) é a proposta de diálogo entre todo o diverso, ou melhor, de conjunção acertada e dramática das várias condições que situam o homem no mundo, seu entrecruzar doce e fecundo, sua irreparável desarmonia que se deplora e compensa em literatura (1999, p. 37).

Além do mais, várias obras dessa fase trazem uma espécie de ternura para com o cidadão humilde, de aproximação para com indivíduos menos favorecidos socialmente; são personagens que, geralmente, possuem inserção menos evidente nos grandes movimentos sociais, vivem apenas as suas pequenas vidas, entrecruzando-se a cada narrativa em suas pequenezas. Um exemplo desse cruzamento de pequenezas está no trecho a seguir, retirado de $O$ Homem Duplicado:

O que por aí mais se vê, a ponto de já não causar surpresa, é pessoas a sofrerem com paciência o miudinho escrutínio da solidão, como foram no passado recente exemplos públicos, ainda que não especialmente notórios, e até, em dois casos, de afortunado desenlace, aquele pintor de retratos de quem nunca chegamos a conhecer mais que a inicial do nome, aquele médico de clínica geral que voltou do exílio para morrer nos braços da pátria amada, aquele revisor de imprensa que expulsou uma verdade para plantar no seu lugar uma mentira, aquele funcionário subalterno do registro civil que fazia desaparecer certidões de óbito (...) (HD, 2002, p.10).

No trecho acima, são citadas personagens várias (o $\mathrm{H}$, de Manual de Pintura e Caligrafia; o Ricardo Reis, de $O$ ano da Morte de Ricardo Reis; o Raimundo de História do Cerco de Lisboa e o Sr. José de Todos os Nomes), de momentos diferentes da escrita saramaguiana. Entretanto todas elas convivem no mesmo espaço da narrativa e possuem a mesma característica: estão perdidas na solidão da pós-modernidade, que as ameaça engolir e petrificar; lutam para alçar-se a uma nova - e melhor - posição na sociedade e, principalmente, lutam para perquirir sua gênese, fundadas em questões de fundo mais ontológico. São, na maioria das vezes, seres depressivos em busca de um sentido para suas vidas. 
O Homem Duplicado pode ser incluído nessa fase da escrita de Saramago: estamos diante de uma narrativa atemporal, quase alegórica, que carrega em si um conglomerado de temas. Isso também nota Reis (2002, p. 15-16) ao dizer que:

Com $O$ Homem Duplicado Saramago constrói um romance que, a exemplo dos três últimos (concretamente: Ensaio sobre a Cegueira, Todos os Nomes e A Caverna), parece contemplar uma história fora (ou quase) do tempo e do espaço. Note-se que este despojamento é tanto mais significativo e evidente quanto é certo que ele representa também uma distância, quase um contraste com aqueles outros romances, de Levantado do Chão até O Evangelho segundo Jesus Cristo, em que os enquadramentos históricos, os cenários sociais e mesmo as figuras compostas possuíam uma grande nitidez de recorte e de caracterização, em muitos casos fruto de indagação minuciosa, verdadeiro trabalho de pesquisa e de documentação, que o escritor, aliás, sempre honradamente assumiu.

Em O Homem Duplicado são as ações simples, sem brilho, que comporão a saga das pequenas, mas nem por isso menos significativas, personagens que nem por isso serão menos heróis na timidez de suas ações.

Dessa perspectiva de ações pequenas, O Homem Duplicado revela ecos de seu protótipo plautino, permitindo-nos entabular uma reflexão sobre a busca do eu e do outro e suas problemáticas.

Finalizado tal aparte, podemos afirmar que o romance saramaguiano, por tratar, em sua trama, da questão da duplicidade, reinventa-a dentro de seu gênero e subverte-a para repensar criticamente a questão da alteridade e seus corolários. Enfim, ao tratar do tema do duplo, do livro de Saramago, conseguimos extrair:

uma noção de alteridade que (...) é a proposta de diálogo entre todo o diverso, ou melhor, de conjunção acertada e dramática das várias condições que situam o homem no mundo, seu entrecruzar doce e fecundo, sua irreparável desarmonia que se deplora e compensa em literatura (SEIXO, 1999, p. 37).

Em O Homem Duplicado, o autor lança mão de uma personagem em crise, que, acidentalmente, descobre não ser uma pessoa singular no mundo. O narrador se incumbe de nos apresentar os sentimentos de Tertuliano Máximo Afonso e António Claro/Daniel Santa-Clara $^{47}$, suas angústias, seus anseios, suas dúvidas, desconfianças, desconfortos, até o ponto em que decidem proceder à troca de identidades, culminando, no desfecho da obra, com a impossibilidade de existir apenas um. Este desfecho, por irônica estratégia de

\footnotetext{
${ }^{47}$ Usaremos durante todo o nosso trabalho o nome composto António Claro/Daniel Santa-Clara para denominar o antagonista, pois ele reflete perfeitamente a condição de dúplice que caracteriza a personagem. O mesmo acontece com a personagem Tertuliano Máximo Afonso, nome cuja repetição completa ao longo de nosso escrito tem cunho proposital, pois objetiva manter seu uso hiperbólico tal qual acontece na obra de Saramago, além de apontar para um paradoxo que comentaremos mais adiante: evoca uma personalidade histórica, eminente, mas não passa de um professor anônimo e inexpressivo, que busca ser reconhecido.
} 
verossimilhança da obra, revela ao leitor a ideia de que a identidade é formada na interação com o outro, sendo impossível existir sem tal.

O romance, sem indicações cronológicas ou topográficas, permite associar o lugar em que se desenvolve a trama a qualquer grande cidade e seus arredores; quanto ao tempo do romance, é o presente, o agora. Assim, a narrativa projeta uma sociedade que reflete a contemporânea, na qual a vertiginosa reificação dos seres acaba por deixá-los desprovidos de suas opiniões.

Ao procurarmos selecionar os elementos para a análise do romance, nosso primeiro passo exige que pensemos a organização e as relações intertextuais que ele apresenta, tarefa em que nos deteremos a seguir.

\subsection{Ordenando o Caos}

O Homem Duplicado retoma o tema da duplicidade presente no Amphytruo plautino para com ele interagir e o atualizar. A estruturação fabular escolhida por Plauto em seu Amphytruo, enfocando principalmente o relacionamento amoroso entre Júpiter e Alcmena, é também a base na qual se apoia Saramago para recriar o tema dos duplicados. Mas, se, em Plauto, o enfoque da peça é tragicômico, baseando-se nos mesmos quiproquós do protótipo mítico, como a troca de identidades entre Júpiter e Anfitrião, Sósia e Mercúrio, em O Homem Duplicado, ao visitar/transgredir/parodiar a forma plautina, Saramago (re)inventa o tema de seu protótipo, valendo-se do topos do duplo, porém conferindo-lhe não mais um enfoque cômico, mas trágico.

Olhar o antigo sob nova óptica, procedendo a uma repetição com distância crítica, ou, nas palavras de Hutcheon, "uma distanciação crítica entre o texto em fundo a ser parodiado e a nova obra que incorpora" (1985, p. 17) exige um trabalho de perscrutação atenta, para não cairmos nas malhas do "tudo é possível" e do "tudo é viável", sem percebermos as boas e más qualidades que cada obra analisada carrega.

$\mathrm{Na}$ constituição da obra, a tessitura do discurso do autor se dá também pelo diálogo com outra obra, ou seja, o texto saramaguiano

surge como um diálogo de textos: toda sequência se constrói em relação a uma outra, provinda de um outro corpus, de modo que toda sequência está duplamente orientada: para $\mathrm{o}$ ato de reminiscência (evocação de uma outra escrita) e para o ato de intimação (a transformação dessa escrita) (KRISTEVA, 1974, p. 98-9). 
Essa relação dialógica que $O$ Homem Duplicado mantém com a peça plautina é, à luz das considerações de Genette (2006), hipertextual. A fábula do texto de Saramago é pautada em inúmeras diferenças em relação ao original latino. Porém seus elementos estruturais e fabulares, mesmo deslocados no tempo, no espaço e no contexto, permanecem os mesmos.

Por acontecer, como já dissemos, em um tempo cronológico atual, a ação da narrativa apresenta uma personagem dominada por uma espécie de depressão; trata-se de um indivíduo que está a “despedaçar-se no seu interior por efeito da solidão, do desamparo, da timidez, daquilo que os dicionários descrevem como um estado afectivo desencadeado nas relações sociais e com manifestações volitivas, posturais e neurovegetativas" (HD, 2002, p. 44). O professor de história Tertuliano Máximo Afonso "anda muito necessitado de estímulos que o distraiam, vive só e aborrece-se, ou, para falar com a exactidão clínica que a actualidade requer, rendeu-se à temporal fraqueza de ânimo ordinariamente conhecida por depressão.” (HD, 2002, p. 9).

Sem muito que fazer, o professor acata a sugestão de seu amigo - o professor de Matemática - de assistir a um filme chamado Quem porfia mata caça, como um modo de desviar-se de seus problemas depressivos - talvez o filme pudesse ser uma ferramenta que o ajudasse a esquecer o seu mal. Por estar ocupado há meses com estudos sobre as antigas civilizações mesopotâmicas, Tertuliano Máximo Afonso reluta em aceitar a ideia do amigo. No entanto acaba cedendo à sugestão. Mas o que teria sido um momento de descontração e distração torna-se o início de um processo investigativo, cujo final é a aniquilação de sua existência, já que culminará na morte de sua identidade de professor e na adoção de uma outra identidade - a de ator de filmes.

Assistindo ao filme, o professor de história nota a presença de um ator que possui sua exata aparência. O mesmo olhar, o mesmo modo de falar, a mesma tonalidade de voz e os mesmos traços físicos. Enfim, Tertuliano Máximo Afonso percebe que ele e o outro não são apenas semelhantes como irmãos gêmeos, mas são iguais, sendo a única diferença entre ambos o bigode usado pela personagem cinematográfica.

A partir desse momento, Tertuliano Máximo Afonso inicia uma busca incessante para saber quem é aquele homem igual a ele. Retornando ao lugar onde locara o primeiro filme, aluga diversos títulos da mesma produtora, tentando identificar um nome de ator comum a todos eles, para tentar localizar o homem que é sua cópia. 
Essa compulsão por saber quem é aquele que se parece consigo faz com que as atividades de Tertuliano Máximo Afonso fiquem sensivelmente prejudicadas, pois troca seus compromissos rotineiros por horas a fio assistindo aos filmes, para isso preterindo trabalho, mãe e até mesmo a namorada, Maria da Paz.

Depois de assistir a dezenas de títulos, a personagem descobre, afinal, que o nome do artista que procura é Daniel Santa-Clara, espécie de pseudônimo de António Claro, atuante em diversos filmes com papéis de pouca expressão: um recepcionista de hotel, em Quem porfia mata caça; um caixa de banco, em $O$ código secreto; um porteiro de cabaré, em $A$ vida alegre; um empresário em A Deusa do Palco e um auxiliar de enfermagem, em A morte ataca de madrugada. A partir daí, Tertuliano decide descobrir quem é esse que é seu duplo, o que ele faz e como vive. Os dois se aproximam, mas, após encontrá-lo, Tertuliano Máximo Afonso fugirá, tentando evitar qualquer tipo de relacionamento ou aproximação que possa gerar alguma mudança na vida de ambos. Mas, como no mundo real é impossível existirem duas pessoas exatamente iguais convivendo em harmonia, o destino, traçado desde o início pelo ditado popular "Quem porfia mata caça" (título do filme que dá origem a toda essa desordem entre as personagens), põe fim a um deles. $\mathrm{O}$ fato de os dois se conhecerem desencadeou a morte de António Claro/Daniel Santa-Clara. Após saber da morte de seu duplo, o professor de história não hesita em assumir a vida do outro como se fosse sua própria vida. Dessa forma, é a existência legítima e original do ser Tertuliano Máximo Afonso que morre. As duas vidas estão tão intimamente ligadas que o fim trágico de um significa a morte do outro, como ocorre com os duplos criados no período do Romantismo e estudados inclusive por RANK (1939, p. 150).

A trama de $O$ homem duplicado dialoga, pois, com o mito de Anfitrião e, por extensão, também está alicerçada na temática do duplo. Acham-se esparsos, pelo texto, indícios que sugerem a existência de uma segunda história, colocada nos interstícios da primeira, e que pode ser detectada pelo leitor. Portanto, a narrativa saramaguiana conta duas histórias: uma evidente e outra secreta; a primeira é visível; a segunda desenvolve-se paralelamente à primeira e já se encontra nela implícita graças aos índices deixados pelo narrador ao longo da narrativa. Índices esses que iremos começar a perscrutar.

Como diz Genette (2003, p. 30), é preciso distinguir dois tipos de hipertextualidade - a simples e a por imitação. Com base nessa distinção feita pelo teórico francês, podemos afirmar que, se a relação do texto plautino com o texto mítico se dava por meio da hipertextualidade simples, a que o texto de Saramago manterá com o de Plauto se 
enquadrará no caso da hipertextualidade por imitação, que ocorre por meio do uso dos mesmos elementos intertextuais de que Plauto se valeu para atualizar em linguagem cênica: o mito grego de Anfitrião.

Porém, dizer apenas hipertextualidade por imitação não basta para definir o que Saramago realiza em sua narrativa. Com efeito, por tratar-se de uma definição muito genérica, Genette vai ampliar essa noção dizendo que

\begin{abstract}
a hipertextualidade como classe de obras é em si mesma um arquitexto genérico, ou antes transgenérico: entendo por isso uma classe de textos que engloba inteiramente certos gêneros canônicos (ainda que menores) como o pastiche, a paródia, o travestimento, e que permeia outros - provavelmente todos os outros (...) (GENETTE, 2006, p. 16)
\end{abstract}

Ainda seguindo a orientação de Genette, podemos constatar que o texto saramaguiano realiza uma paródia do texto plautino. Muito se tem a dizer sobre a paródia e suas formas e funções, mas, como nosso propósito aqui é outro, para não nos delongarmos demais no assunto, adotaremos diretamente o conceito de Hutcheon sobre paródia.

A esse respeito, a teórica nos diz que a paródia não é um fenômeno novo e que, com o advento do século XX, adquire funções que ultrapassam a mecânica das atividades metadiscursivas, deixando de ser considerada um gênero menor, parasitário e derivativo de reter apenas a função conservadora de imitação ridicularizante. Considerada por Hutcheon como "uma das formas mais importantes da moderna auto-reflexividade e uma forma de discurso interartístico" (HUTCHEON, 1985, p. 13), ela adquire uma função hermenêutica com inferências culturais e ideológicas e, mais ainda, apresenta-se como auto-reflexiva, repleta de duplicidades, revelando-se mais como inversão irônica e jocosa, com convenções múltiplas, do que como uma imitação ridícula e nostálgica do passado. Sendo assim, Hutcheon acrescenta que

(...) a definição de paródia como imitação com diferença crítica impede qualquer adesão às implicações aperfeiçoadoras das teorias dos formalistas, concedendo, obviamente, acordo à ideia geral da paródia como inscrição de continuidade e mudança. (...) Penso que ela expressa certos denominadores comuns a todas as teorias da paródia, para todas as épocas, mas constitui para mim uma necessidade particular ao tratar da arte paródica moderna. (...) Por essa definição a paródia é, pois, repetição, mas repetição que inclui diferença (DELEUZE, 1968); é imitação com distância crítica, cuja ironia pode beneficiar e prejudicar ao mesmo tempo (1985, p. 53-54).

Já antes havíamos observado que o texto saramaguiano olha o velho sob nova óptica. Entretanto, parodiando os pequenos detalhes do Amphytruo e formando novos contextos, $O$ Homem Duplicado reivindica para si uma identidade própria. 
Sob a égide de uma aemulatio ${ }^{48}$ que se quer crítica, o texto de Saramago começa a revelar suas hipertextualidades. Temos, por um lado, o diálogo de $O$ Homem Duplicado com a peça plautina; por outro, a construção desse romance se ancora nas bases da poética aristotélica, uma construção que, além da aemulatio, se erige sob a égide da contaminatio $^{49}$. Construindo um discurso sinuoso, cheio de entraves e de subentendidos, o narrador incorpora a seu discurso vários gêneros literários ${ }^{50}$, permitindo-nos identificar o perfil da tragédia aristotélica em vários momentos da trama. Vejamos, a título de exemplificação, três momentos em que o elemento teatral contamina o romance.

O primeiro acontece logo à página 132, a quarta do capítulo oito. Nela lemos: “o tempo manter-se-á parado como um palco deserto. (...) Quer limpar o terreno, não deixar rastos, o primeiro acto acabou, é hora de retirar os adereços de cena" (HD, 2002, p. 132, grifos nossos). Aqui poderíamos pensar que o narrador usa esta linguagem por se tratar de um filme ou uma tomada de cena para se montar um filme, já que o outro de mesma aparência que Tertuliano Máximo Afonso é um ator. Entretanto o palco, local por excelência do espetáculo teatral, aí se instala, suscitando dúvidas e questionamentos no leitor mais atento. Se ficam dúvidas quanto a essa afirmação do narrador, ao passarmos à página seguinte, a ideia de cena e ato retornam, deixando esse leitor mis astuto ao menos suspeito e mais ciente das intenções do narrador de $O$ Homem Duplicado:

Compreendeu que estava a precisar de uma pausa, um intervalo de descanso, nem que fosse uma semana ou duas, o tempo de chegar a resposta da produtora, um período em que fizesse de conta que nunca tinha visto Quem Porfia Mata Caça nem o empregado da recepção do hotel, sabendo no entanto que esse falso sossego, essa aparência de tranquilidade teriam um limite, um prazo à vista, $e$ que o pano, chegando a hora, inexoravelmente abriria para o segundo acto (HD, 2002, p. 133, grifos nossos).

Por fim, um terceiro momento revelador dessa contaminação pode ser identificado quando o narrador se refere a um possível diálogo entre Tertuliano Máximo Afonso e a mãe de Maria da Paz, como vemos no fragmento abaixo:

Tertuliano Máximo Afonso marcou o número do telefone de Maria da Paz, provavelmente atendê-lo-ia a mãe, e o breve diálogo seria mais uma pequena

\footnotetext{
${ }^{48}$ Concorrer com o autor, desejar fazer, em nossa língua, tão bem quanto ele na sua.

49 A contaminação. Em outras palavras: ex multis unam facere (de muitas fazer uma). Ou seja, se valer de dois ou mais bases para construir seu texto.

${ }^{50}$ Infelizmente não temos como nos deter nos diversos gêneros que a narrativa saramaguiana explora no corpo do texto. Mas fique, a título de exemplo, além da tragédia aristotélica, o discurso corrido e dinâmico que faz lembrar as narrativas policiais e as do gênero fantástico. Além dessas, ainda há algumas ligações com o gênero da novela e com a própria temática do duplo, que veremos adiante.
} 
comédia de fingimentos, grotesca e com um ligeiro toque de patético (...) (HD, 2002, p. 122).

Assim, podemos perceber que a narrativa saramaguiana traz em seu bojo múltiplos diálogos que tentaremos, aos poucos, investigar. Como nosso intuito se restringe a analisar os elementos intertextuais que a trama revela, iremos nos deter nos quatro elementos já estudados - acréscimos, supressões, inversões e deslocamentos -, recorrendo, sempre que preciso, aos diálogos que a obra estabelece com a poética aristotélica ou com outras obras que ela nos aponta. Para tanto, retomamos os conceitos abordados no capítulo anterior sobre os elementos intertextuais e vamos usá-los como referência para estudarmos a narrativa saramaguiana.

\subsubsection{Acréscimos}

Quando pensamos nos acréscimos realizados por Saramago em seu romance, não podemos nos esquecer de que, além de Plauto, o escritor português se vale do topos do duplo para recriar as bases do mito anfitriônico. Em razão disso, um dos primeiros acréscimos realizados pelo escritor de Ensaio sobre a Cegueira reside na figura das personagens, das quais duas são acrescidas para proporcionar um melhor desenvolvimento da trama romanesca.

Essas personagens se fazem necessárias devido às diversas duplicações que o romance de Saramago apresenta, mas também são passíveis de se relacionar ao teatro plautino. Dentre elas, na narrativa romanesca acontece a duplicidade por espelhamento entre as personagens Helena e Maria da $\mathrm{Paz}^{51}$. Acreditamos que a figura de Helena, mulher de António Claro/Daniel Santa-Clara, reflete Maria da Paz e, em sua construção, é a expressão da mulher que é, num primeiro momento, dedicada a seu homem e luta pelos seus desejos e por sua felicidade. Aliás, isso é até indiciado ao leitor quando o narrador diz ser "Helena como similar a Maria da Paz nas suas obrigações de empregada, aquilo do trabalho regular e das entradas e saídas a horas certas (...)” (HD, 2002, p. 252).

Sem paz interior e um tanto quanto depressiva - "A Helena têm-na ajudado os tranquilizantes (...) (HD, p. 231)" -; Helena é, no fim das contas, uma mulher em busca de felicidade. Sua busca é semelhante à Maria da Paz, o reflexo - e não poderia deixar de ser, por sua categoria de personagem duplicada na narrativa - da busca de Maria da Paz, uma

\footnotetext{
${ }^{51}$ Outras duplicações serão analisadas no quarto capítulo deste trabalho.
} 
espécie de imagem duplicada, que tenta viver sua vida ao lado do homem que diz amar, expressando, assim, uma semelhança com a vida de Maria da Paz.

A segunda personagem acrescentada por Saramago é Dona Carolina, mãe de Tertuliano Máximo Afonso. Esta, apesar de não existir na peça do escritor latino, assume, no romance, foros de um Tirésias deslocado, que antecipa, a todo momento, a tragédia que está por sobrevir. Sua função na obra está mais ligada à personagem Senso Comum que propriamente às outras personagens da trama. Importa-nos perceber, por fim, que Dona Carolina integra um rol de personagens femininas dos romances saramaguianos e tem, tal qual suas "semelhantes", uma autoridade e personalidade fortes, que incitam o filho a caminhos contrários ao trágico, valorizando sua subjetividade e dando qualidades é(sté)ticas que privilegiam a identidade em formação de Tertuliano Máximo Afonso:

Como tal, sabe tudo de telefones que às vezes tocam sem ser esperados e de outros que tocam às vezes quando desesperadamente se esperava que tocassem. Não foi este o caso de agora, a mãe de Tertuliano Máximo Afonso só tem andado a perguntar-se, Quando será que o meu filho me telefona, e eis que de repente tem a sua voz juntinha ao ouvido, Bons dias, minha senhora mãe, como tem passado, (...) Quer dizer que antes de um mês estarás aqui comigo, Irei vê-la, claro, mas não poderei ficar mais que três ou quatro dias, Porquê, É que tenho ainda umas coisas para arrumar aqui, umas voltas a dar, Que coisas são essas, que voltas, a escola fecha para férias e as férias, que eu saiba, fizeram-se para descanso das pessoas, (...) Tem algo que ver com a tua amiga, a Maria da Paz, Até certo ponto, Pareces uma personagem de um livro que tenho andado a ler, uma mulher que quando lhe perguntam responde sempre com outra pergunta, Repare que as perguntas as tem feito a mãe, a minha, e única, foi para saber como tem passado, É porque não me falas claro e direito, dizes acho que sim, dizes até certo ponto, não estava habituada a que fizesses mistérios comigo, Não se zangue, Não me zango, mas tens de compreender que estranhe que, entrando tu de férias, não venhas logo para aqui, não me lembro de que isso tenha alguma vez sucedido, Depois the contarei tudo, Vais fazer alguma viagem, Outra pergunta, Vais, ou não vais, Se fosse dizia-lho, O que eu não percebo é por que disseste que a Maria da Paz tinha que ver com esses assuntos que te obrigam a ficar, Não é tanto assim, devo ter exagerado, Estás a pensar em casar-te outra vez, Que ideia, mãe, Pois talvez devesses, As pessoas agora casam-se pouco, com certeza já deduziu isso dos romances que tem lido, Não sou estúpida e sei muito bem em que mundo vivo, o que penso é que não tens o direito de andar a empatar a rapariga, Nunca lhe prometi casamento nem lhe propus vivermos juntos, Para ela, uma relação que dura há seis meses é como uma promessa, não conheces as mulheres, Não conheço as do seu tempo, E conheces pouco as do teu, É possível, realmente a minha experiência de mulheres não é grande, caseime uma vez e divorciei-me, o resto conta pouco, Há a Maria da Paz, Também não conta muito, Não te dás conta de que estás a ser cruel, (...) (HD, 2002, p. 135-36)

O trecho demonstra as duas qualidades de Dona Carolina: sua capacidade sibilina e sua incitação à valorização identitária, ética e estética do filho. Assim, ao questioná-lo ininterruptamente, Dona Carolina obriga-o a tomar atitudes de cunho ético em relação a seu compromisso com Maria da Paz, desafiam-no a fugir da calmaria identitária que sua 
vida apresenta e a assumir uma função de ente responsável por seus atos, além de exigir dele uma postura social que valorize o respeito e a proximidade para com a família, representada, neste caso, pela própria mãe. Todas essas exigências de Dona Carolina induzem Tertuliano Máximo Afonso a um posicionamento, em face dessas mesmas exigências, que demanda agregação de valores - tais como família, casamento, responsabilidade para com a mãe, respeito ao próximo e a seus sentimentos - e, enfim, respeito à sua própria identidade.

Quanto à forma de estruturação da narrativa, o tempo e o espaço também apresentam acréscimos em relação a Plauto. Em Amphitruo, o espaço dramático era apenas a casa de Alcmena e o tempo, inferior a vinte e quatro horas, como era comum no teatro da Antiguidade. Já na vida pós-moderna retratada em O Homem Duplicado, o tempo e o espaço multiplicam-se, dando uma dimensão mais humana à história e aprofundando o relacionamento entre as personagens. Assim, surgem vários espaços, entrecortados por curtos tempos narrativos.

Dentre esses espaços merece destaque a casa de Tertuliano Máximo Afonso, na qual a personagem passa a maior parte do tempo, sendo quase um casulo protetor que assume o lugar de ventre materno. É nela que a personagem assiste ao filme que lhe mostrará seu duplo; nela o professor se mascara para poder ir à procura do ator do filme; nela ele se encontra com sua namorada Maria da Paz e nela ainda tomará outras pequenas atitudes que lhe possibilitarão refugiar-se do mundo que as paredes escondem.

Além do espaço da casa de Tertuliano Máximo Afonso, um outro espaço de grande importância é a cidade, espaço de múltiplas vozes, em que a vida é quase engolida em favor de uma identidade social que não passa de fingimento, falso espaço de felicidade, irrealidade, que traga e enlouquece o ser humano em busca de si mesmo.

É a altura de informar aqueles leitores que. ajuizando pelo carácter mais que sucinto das descrições urbanas feitas até agora, tenham criado no seu espírito a ideia de que tudo isto se está a passar numa cidade de tamanho mediano, isto é, abaixo do milhão de habitantes, é a altura de informar, dizíamos, que, muito pelo contrário, este professor Tertuliano Máximo Afonso é um dos cinco milhões e pouco de seres humanos que, com diferenças importantes de bem-estar e outras sem a menor possibilidade de mútuas comparações, vivem na gigantesca metrópole que se estende pelo que antigamente haviam sido montes, vales e planícies, e agora é um sucessiva duplicação horizontal e vertical de um labirinto, de começo agravada por componentes que designaremos por diagonais, mas que, no entanto, com o decorrer do tempo, se revelaram até certo ponto equilibradores da caótica malha urbana, pois estabeleceram linhas de fronteira que, paradoxalmente, em lugar de terem separado, aproximaram. $O$ instinto de sobrevivência, também disso se trata quando da cidade falamos, vale tanto para os animais como para os inanimais, termo reconhecidamente abstruso que não consta dos dicionários e que tivemos de inventar para que, com suficiência e 
propriedade, pudéssemos tornar transparentes, à simples vista, quer pelo sentido corrente da primeira palavra, animais, quer pela inopinada grafia da segunda, inanimais, as diferenças e as semelhanças entre as coisas e as não coisas, entre o inanimado e o animado. A partir de agora, ao pronunciar a palavra inanimal estaremos a ser tão claros e precisos como quando, no outro reino, já de todo perdida a novidade do ser e das suas designações, indiferentemente chamávamos ao homem animal e animal ao cão. (HD, 2002, p. 70-1, grifos nossos)

A cidade do romance é um espaço muito amplo, que "contracena" com os espaços fechados de dentro da casa. Trata-se de um "formigueiro de cinco milhões de habitantes irrequietos, que são muitos os acidentes e os acidentados muitos mais, que é necessário identificá-los, ir depois à procura das famílias, tarefa nem sempre fácil porque há pessoas tão descuidadas que vão para a estrada sem ao menos um papel no bolso que previna, (...)" (HD, p. 300). Um espaço tão complexo que o narrador tem a necessidade de criar um termo - inanimal - para poder identificá-la. É neste universo labiríntico que habitam as personagens de $O$ Homem Duplicado, cujas mentes parecem assimilar a atmosfera urbana e penetrar em seus insondáveis e tortuosos caminhos. Um espaço privilegiado para se viver uma situação de limiar, em que há uma passagem do ninho fechado para um aberto não limitado. Esse espaço, uma espécie de fronteira entre a paz e a turbulência, carece de um fundamento externo que lhe dê estabilidade, justificando, assim, sua identificação como espaço do limiar.

Outros espaços ainda são acrescidos ao romance, tais como a casa de campo onde se encontram Maria da Paz e António Claro/Daniel Santa-Clara, a casa em que o ator vive com sua mulher, a escola onde trabalha Tertuliano Máximo Afonso, o estúdio de trabalho de António Claro/Daniel Santa-Clara, a casa de Dona Carolina, dentre outros que vão surgindo conforme a narrativa se vai desenvolvendo. Entretanto, comparados aos espaços da casa do professor de história e da cidade na qual ele vive, os demais são de menor importância para a significação da análise que aqui realizamos. Por conta dessa sobreposição de valores, não nos deteremos neles de forma mais alongada.

Por fim, um último detalhe é o de que sabemos qual é a origem de Tertuliano Máximo Afonso e conhecemos a sua família antes da descoberta de seu duplo. Temos conhecimento de que já fora casado, é professor de história, tem uma mãe com a qual mantém contato e possui uma noiva. De Anfitrião, ao contrário, só sabemos, no momento em que se inicia a tragicomédia, que é um guerreiro, que estava em batalha e que deixara sua mulher grávida esperando-o. Em O Homem Duplicado, esse detalhe amplia-se na possibilidade de vingança que Tertuliano Máximo Afonso tem ao poder deitar-se com 
Helena, o que não ocorre no texto de Plauto, pois Anfitrião não tem oportunidade da vingança.

Todos esses acréscimos trazem um elemento novo, que atualiza, dentro da forma romance, o mito resgatado pelo escritor latino em sua peça. Assim, Helena, Dona Carolina e o Professor de Matemática são personagens que trazem a novidade da vida pós-moderna para a narrativa saramaguiana. A primeira retoma a seriedade da matrona, mas de forma diferenciada, tendo como modelo especular não Alcmena, e sim Maria da Paz. Já Dona Carolina reatualiza a figura do adivinho, mas de forma mais emocional que racional, pois, desta vez, não é o poder divino quem lhe confere o dom da predestinação, e sim sua experiência de mulher madura e bem vivida.

Os espaços que se multiplicam na narrativa possuem a função de exprimir, na economia romanesca, que os tempos contemporâneos se expandem de forma mais alargada que na época clássica; assim, temos uma variedade de espaços na narrativa saramaguiana em contraposição a um único espaço na peça plautina. Isso nos prova que Saramago, tal qual Dostoiévski, "não copiou nem expôs [seus] protótipos, mas os reelaborou de maneira livremente artística, convertendo-os em imagens artísticas vivas das ideias, rigorosamente como o faz um artista até com seus protótipos humanos". Dessa forma, Saramago "revelou na imagem dessa ou daquela ideia não só os traços histórico-reais dessa imagem, presente no protótipo (...), mas também as suas possibilidades, e essas possibilidades são justamente o mais importante para a imagem artística" (BAKHTIN, 1997, p. 90).

\subsubsection{Supressões}

Quanto às supressões que o texto saramaguiano realiza em relação a seu protótipo, as ingerências saramaguianas são grandes quanto às personagens: no texto do escritor, temos duas supressões em relação a seu paradigma, pois as personagens Sósia e Mercúrio desaparecem na recriação saramaguiana.

Assim, se na peça plautina tínhamos a figura de dois deuses que se transmutavam em dois seres humanos, em O Homem Duplicado a presença de um desses deuses Mercúrio - é suprimida em favor da economia narrativa do escritor português. Além disso, Mercúrio deixa de existir na narrativa por esta não expressar mais um mundo clássico, pautado no mito e na crença em seres superiores, que podem guiar e influenciar nossa 
história de vida. Tal supressão indica que a condição religiosa questionada por Plauto é suprimida no romance saramaguiano.

Outro fator que ainda dá sustentação ao fato de Mercúrio ter sido suprimido da narrativa dos tempos líquidos está no fato de que tanto ele quanto Sósia eram servos: Mercúrio, servo de Júpiter, e Sósia, servo de Anfitrião. A função do escravo e do serviçal está relacionada ao contexto histórico da época que a peça plautina retrata. Destarte, se, na época clássica, o regime era escravocrata, no período pós-moderno em que se passa a ação do romance de Saramago, esse regime já foi extinto, justificando a supressão tanto de Mercúrio quanto de Sósia.

Por fim, ambas as personagens plautinas são testemunhas e cúmplices de seus senhores. Já no romance só há um par de duplicados, que não têm a conivência de ninguém para as decisões que tomam. Mesmo Maria da Paz e Helena, respectivamente noiva e esposa dos duplicados, não compactuam com eles nem na busca dos respectivos sósias, nem no enfrentamento entre ambos. Se as personagens saramaguianas vivem em uma sociedade líquida $^{52}$, a solidez que a antiga sociedade moderna possuía foi, passo a passo, suplantada por uma nova sociedade mais ágil e dinâmica, em que os processos - muitas vezes - são ultrapassados ou transformados segundo a necessidade e disponibilidade do instante em que surgem, o que faz com que a metáfora da liquidez se encaixe aqui de modo exato.

Diferentemente do que ocorre na peça de Plauto, em que Anfitrião conta com a ajuda de Sósia e o apoio de Blefarão para o confronto com seu duplo, Tertuliano Máximo Afonso não possui nenhuma ajuda para trilhar o caminho da busca e enfrentamento de sua identidade; a ajuda, na sociedade líquida, foi suprimida da ação humana, e, consequentemente, suprime-se também a necessidade de ajudantes ou de pessoas que possam servir de amparo. O sujeito liquefeito dessa sociedade sem contornos definidos é narcisista e vazio por natureza, já que está no centro da crise que essa sociedade apresenta.

Uma boa ilustração dessa atitude tipicamente liquefeita está no trecho em que Tertuliano Máximo Afonso demonstra não querer pedir ajuda a Maria da Paz para descobrir quem é seu duplo. Temos então:

\footnotetext{
52 Tomamos o conceito de Modernidade Líquida emprestado do sociólogo polonês Zigmunt Bauman (2005), que, em seu livro $A$ Modernidade Líquida, define-a como uma sociedade na qual não há mais a fixidez de crenças, atitudes e conceitos. Trata-se de uma sociedade mais moderna, em que a mudança é contínua e demasiadamente rápida. Assim, adotamos esse conceito para alicerçar nossa análise tendo em vista que a sociedade líquida seria um sinônimo de sociedade pós-moderna.
} 
Ninguém o diria vendo-te como eu te vi, despenteado, de roupão e chinelos, a barba por fazer, rodeado de cassetes por todos os lados, não te parecias em nada ao ajuizado, ao sensatíssimo homem que eu cria conhecer, Estava à vontade, sozinho em casa, compreende-se, mas, já que falaste no assunto, tive uma ideia que poderia facilitar e apressar o trabalho, Espero que não tenciones pôr-me também a ver os teus filmes, não fiz nada que merecesse o castigo, Fica tranquila, os meus ferozes instintos não chegam a esse extremo, a ideia seria simplesmente escrever à empresa produtora pedindo-lhes um conjunto de dados concretos, relacionados, em especial, com a rede de distribuição, a localização das salas de exibição e o número de espectadores por filme, creio que me seria muito útil e me ajudaria a tirar algumas conclusões, Não vejo bem o que tenha isso que ver com os sinais ideológicos de que andas à procura, Pode ser que não tenha tanto quanto imagino, em todo o caso quero tentar, Tu saberás, Sim, mas há um pequeno problema, Qual, Não gostaria de ser eu a escrever essa carta, E por que não vais lá falar pessoalmente, há assuntos que se resolvem melhor cara a cara, e aposto que eles ficariam lisonjeados, um professor de História a interessar-se pelos filmes que produzem, E precisamente o que não quero, misturar a minha qualificação científica e profissional com um estudo que está fora da minha especialidade, Porquê, Não saberia explicar, talvez uma questão de escrúpulo, Então não estou a ver como irás solucionar uma dificuldade que tu próprio estás a criar, Poderias ser tu a escrever a carta, Aí está uma ideia absolutamente disparatada, explica-me como vou eu escrever uma carta a tratar de um assunto para mim tão misterioso como a língua chinesa, (HD, 2002, p. 123-24)

O professor de história resiste ao máximo em pedir o favor à Maria da Paz, mas, como não tem outra alternativa, acaba cedendo, ainda que a contragosto, e sempre esperando que ela se disponibilize a ajudá-lo sem muitas perguntas. Assim, é a situação social e econômica do sistema capitalista retratada no romance que obriga Saramago a suprimir os servos plautinos.

No texto de Plauto a história termina com Alcmena grávida de Hércules, filho que Júpiter nela gerara. Já no romance saramaguiano não há filhos de nenhuma parte. A duplicidade, no romance, não gera vida, e sim a morte.

Outro elemento que retoma a trama do Amphytruo plautino, mas de forma suprimida, é que, em $O$ Homem Duplicado, não há a presença de deuses que possam solucionar, ex machina, os conflitos existentes. Os deuses não existem. O Homem Duplicado expressa o fim, por parte da sociedade pós-moderna, da crença nos deuses. Se antes os deuses eram desacreditados por seus atos, agora a tecnologia ocupou seu lugar, por isso os deuses já não têm espaço para viver no mundo moderno. A crença teísta tornase coisa do passado e, mais do que isso, é colocada na clandestinidade, como se fosse um grande problema para a humanidade. Se os deuses dão um sentido e fundamentam o texto plautino, hoje eles já não têm valor algum, como podemos ver em

Alea jacta est, murmurou para os seus adentros, não há mais que discutir, o que tiver de acontecer, acontecerá, não poderá escapar a si mesmo. O rubicão é esta porta que se fecha, esta escada que se desce, estes passos que levam àquele automóvel, esta chave que o abre, este motor que suavemente o faz deslizar pela 
rua fora, a sorte está lançada, agora os deuses que decidam. Este mês é Agosto, o dia é sexta-feira, há pouco trânsito de carros e pessoas, tão longe estava a rua aonde se dirige e de repente fez-se perto. É noite há mais de meia hora (HD, 2002, p.284-85).

Aqui, dotado de uma fina ironia, o narrador saramaguiano consrtói seu relato de forma a antecipar certos acontecimentos, e, numa espécie de diminuição do elemento religioso, deixa a decisão - que já sabemos qual é - nas mãos dos deuses - dando a entender que, na verdade, os deuses não decidem nada por vontade própria.

$\mathrm{O}$ excerto em questão começa com uma famosa frase latina: alea jacta est (a sorte está lançada), pronunciada por Júlio César antes de cruzar o Rubicão. Ora, se este é o contexto da frase, sabemos que César cruza o Rubicão e consegue sair-se vitorioso. Ao trocar de lugar com António Claro/Daniel Santa-Clara, o professor de história está em frente do apartamento de seu sósia, sem saber se entra ou não para passar a noite com a mulher do outro. Pela menção à frase de César, sabemos que a personagem, para cumprir a ação que a expressão antecipa, adentrará o recinto e dormirá com a mulher do ator. Ou seja, cumprirá sua missão, tal qual Júlio Cesar cumpriu a dele - e, parodicamente, tal qual Júpiter cumpriu a sua. Destarte, se o discurso narrativo vale-se de uma prolepse para nos antecipar o que há de se passar, qual a necessidade de recomendar aos deuses que tomem a decisão em relação ao resultado do gesto do herói, senão pelo motivo óbvio de diminuí-los e menosprezá-los?

Não encontrando sustentação cabível no discurso religioso, o que o romance faz é dessacralizá-lo por meio de uma supressão irônica da crença expressa no texto plautino. Se antes era a religião que tudo resolvia, agora se delega a ela apenas aquilo cuja solução já sabemos qual será. Como expressa Bauman (2005), na sociedade líquida ou pós-moderna, "a ideia de eternidade, duração perpétua ou valor permanente, imune ao fluxo do tempo, não tem fundamento na experiência humana." (2005, p. 80). A igreja e sua doutrina foi banida, sendo impossibilitada de surgir, ex machina, ao final do romance, para tudo resolver. Ela já não é mais um órgão promissor, capaz de salvar. É apenas uma opção descartada pela sociedade, como diz o sociólogo polonês:

Para a grande maioria dos habitantes do líquido mundo moderno, atitudes como cuidar da coesão, apegar-se às regras, agir de acordo com os precedentes e manter-se fiel à lógica da continuidade, em vez de flutuar na onda das oportunidades mutáveis e de curta duração, não constituem opções promissoras (BAUMAN, 2005, p. 60).

Interrompido seu milenar poder, a Igreja se vê sem forças ou voz dentro da sociedade atual. Aqueles que ainda acreditam nela são privados, por essa própria 
sociedade, e estigmatizados como fracassados na vida, derrotados, desvalorizados por meio de uma dita inferioridade social. Apesar de o romance saramaguiano não falar diretamente dessa "diluição" da força religiosa - mesmo conhecendo o ateísmo do escritor -, ele o sugere em suas entrelinhas, como podemos constatar no seguinte excerto:

É de todos conhecido, porém, que a enorme carga de tradição, hábitos e costumes que ocupa a maior parte do nosso cérebro lastra sem piedade as ideias mais brilhantes e inovadoras de que a parte restante ainda é capaz, e se é verdade que em alguns casos essa carga consegue equilibrar desgovernos e desmandos de imaginação que Deus sabe aonde nos levariam se fossem deixados à solta, também não é menos verdade que ela tem, com frequência, artes de submeter subtilmente a tropismos inconscientes o que críamos ser a nossa liberdade de actuar, como uma planta que não sabe por que terá sempre de inclinar-se para o lado de onde lhe vem a luz. (HD, 2002, p. 86)

O narrador, ironicamente, comenta que a tradição e o hábito deturpam as ideias brilhantes que a sociedade produz. Sabemos que a religião é um costume por demais enraizado na sociedade e que, por suas crenças, já interveio em grandes fatos da história do homem. Exemplo são as Cruzadas ou a Inquisição, que sobrepujaram, por conta da crença, a situação histórica do homem. Dessa forma, quando o narrador de O Homem Duplicado critica o hábito e a tradição, ele critica também - indiretamente - a religião, expulsando-a do contexto pós-moderno.

Por fim, as supressões observadas no romance saramaguiano editam novas perspectivas sobre a questão pós-moderna, relativizando as antigas crenças e opiniões e instaurando, dentro do novo modelo de sociedade, uma visão líquida em relação à mesma.

\subsubsection{Inversões}

O romance do escritor português também apresenta várias inversões. A primeira delas acontece na representação. No Amphytruo, temos Júpiter, um deus, e Anfitrião, um guerreiro mortal. Duas figuras, uma das quais expressando a humanidade; a outra, os Campos Elíseos. Já no romance os duplicados são representantes dos homens, personagens comuns da sociedade atual: um professor de história e um ator. Se, na peça, tínhamos um embate entre deuses e homens, aqui temos esse embate invertido, pois acontece somente entre seres humanos.

A outra inversão se refere ao confronto. No romance, Tertuliano Máximo Afonso é advertido o tempo todo a evitar o confronto com seu duplo. Já Anfitrião nem pode retroceder e deixar as coisas como estão; ele precisa ir até as últimas consequências para 
provar que é o verdadeiro Anfitrião e que seu duplo é o sósia, Júpiter. O confronto é estimulado por todos, pois é a honra de Anfitrião que está posta em jogo.

As duas inversões do protótipo plautino realizadas por Saramago em O Homem Duplicado se justificam; são necessárias para expressar a identidade e as mudanças dos homens da sociedade pós-moderna, possibilitando que a diferença criada pelo autor seja líquida e que a paródia cumpra sua função de incorporadora de outros discursos, mas de forma reavaliadora e desafiadora.

As outras inversões que acontecem no romance se deslocam das personagens para a estrutura e a interdiscursividade temática que o romance possui em relação à peça plautina.

Quanto à estrutura, a inversão do romance saramaguiano está na forma como o ambiente é tratado por seu escritor. A peça principia e termina em um ambiente de paz, seguindo as tendências do modelo plautino. Entretanto, o romance de Saramago inverte essa proposição ao principiar em um ambiente de paz, mas terminar em um ambiente de explosivo. A morte do duplicado, a ligação de um triplicado e o uso da arma por parte de Tertuliano Máximo Afonso diluem o ambiente em um clima de insegurança, mistério e nervosismo. O romance não se finaliza, deixando em aberto - tal qual o modelo de sociedade que expressa - as possibilidades de ação da personagem quando esta se encontrar com seu triplicado. A inversão assume um ar de tragicidade por conta da morte anteriormente narrada e pela arma que Tertuliano Máximo Afonso carrega, propondo uma inversão paródica de seu modelo, pois expressa que, neste novo contexto, a paz jamais será alcançada pela personagem principal.

No que diz respeito aos temas, a inversão se dá de modo interdiscursivo, revelando as diversas possibilidades expressas em relação a seu protótipo.

Dessa forma, temos, no romance, uma função invertida dos duplos. Na peça teatral, Júpiter se dá a conhecer a Anfitrião no final da comédia, colocando as coisas em seus devidos lugares. Já no romance, a procura por desvendar-se a si mesmo para não perder a unicidade não tem fim. Essa busca infindável tem seu início na primeira página da história e termina com um telefonema de um outro duplicado, na última página. A inversão, no romance, nos mostra que este sujeito da modernidade é fragmentado e sua vida e ações são moldadas pelo outro.

O fruto do engano, na peça, é um filho, e a compensação da injustiça divina estará na glória dos atos heróicos que esse filho realizará. Hércules, filho que Júpiter gerad em Alcmena, deve ser motivo de orgulho para o mortal Anfitrião. O romance, entretanto, 
inverte essa situação, tornando a morte de António Claro/Daniel Santa-Clara e Maria da Paz o fruto do engano. Tertuliano Máximo Afonso, inversamente ao que ocorre em seu protótipo, não terá glória nenhuma ao saber da morte dos dois e seu lucro não será um filho, e sim um fardo.

Se Tertuliano Máximo Afonso é uma personagem que possui como protótipo Anfitrião, temos que o espírito da personagem do romance de Saramago também é invertido frente ao modelo latino. Tertuliano, mesmo antes de saber-se duplicado, é um homem com dificuldades em tomar decisões, apático, sem nenhuma motivação para a vida. Anfitrião, por sua vez, é um guerreiro, sai em batalha, vence-a e sabe para quem e para onde voltar.

Assim, se essa inversão acontece com as duas personagens masculinas, ela também acontecerá com as femininas. Alcmena, sendo protótipo de Maria da Paz, expressará uma função inversa àquela que Maria da Paz terá. Dessa forma, tanto Maria da Paz quanto Alcmena tiveram a experiência da individuação. Ambas conheceram na intimidade os duplicados. No entanto, Alcmena sobreviverá e lutará para defender sua honra e decifrar sua própria história, enquanto, no romance de Saramago, Maria da Paz não sobrevive para contar a história e permanecer nela. A personagem é morta para representar o inverso de seu modelo. Ela morre, uma vez que a história já não será a de uma vitória e coroação do ser humano por um deus, mas sim a da derrota do ser humano por suas fraquezas, vícios e desentendimentos.

A peça de Plauto não tem a preocupação de discutir a identidade do indivíduo; o tema da duplicação apresentado por ela é o viés para o cômico. No romance, a duplicação das personagens é o tema da busca interior como força motriz para conduzir o homem a um encontro consigo mesmo, convertendo-se essa comicidade em tragicidade. Essa inversão da questão identitária faz com que a continuidade do romance se dê pela morte e não pela vida. Tertuliano Máximo Afonso morre enquanto sujeito, para que ele mesmo sobreviva na persona do ator António Claro/Daniel Santa-Clara.

Outra inversão que tem como parâmetro a peça plautina refere-se à ajuda que a personagem principal recebe. Diferentemente do que ocorre na obra de Plauto, em que Anfitrião conta com a ajuda de amigos de batalha para o confronto com seu duplo, Tertuliano Máximo Afonso trilha sozinho o caminho da busca e enfrentamento, atitude que revela a solidão do ser humano na época pós-moderna. Esse fato exige que exista uma última inversão. Pois se o homem solitário tem de enfrentar sozinho seus problemas, o 
romance não gerará a vida, e sim a morte. No texto plautino, a história termina com a heroína grávida, enquanto no romance não há fillhos de nenhuma parte, o solidão impede que a vida seja gerada.

\subsubsection{Deslocamentos}

Relativamente aos deslocamentos, os primeiros a acontecer são em relação à qualidade das personagens, que são reeditadas de forma paródica no romance saramaguiano. Assim, podemos iniciar nossa análise detendo-nos na transposição, para as páginas do romance do escritor português, da figura da bela Alcmena plautina, que será vertida em Maria da Paz. Porém, essa transposição possui certas modificações que prefiguram uma inversão: se, na narrativa plautina, Alcmena não possui uma alma de heroína trágica, em $O$ Homem Duplicado Maria da Paz terá essa alma trágica que falta à matrona latina.

Tal alma já se delineia no nome de Maria da Paz. O nome da personagem porta, alegoricamente, a revelação de uma de suas facetas: sua aproximação em relação à figura de Maria, mãe de Jesus. Tanto a mãe de Jesus quanto a namorada de Tertuliano Máximo Afonso carregam as semelhanças de serem penitentes, caridosas e donas de trajetórias de vida dedicadas ao homem e à sua humanização.

Desse modo, tanto Alcmena quanto Maria da Paz são símbolos da fertilidade e expressam, seja no nome, seja na vocação, a graça da fertilidade. Entretanto, se a figura bíblica tem sua marca carregada de passividade, as personagens de Plauto e de Saramago não são assim tão passivas, mas, ao contrário, marcadas pela autoridade. Ao lermos os excertos a seguir, podemos constatar tais aspectos:

\footnotetext{
Não é verdade que, na existência, na juventude, há muito poucos prazeres, ao lado do que nos causa dor? Pode-se fazer uma verificação na vida dos homens. Mas foi isso que os deuses quiseram: que a dor sempre acompanhasse o prazer. Assim que alguma coisa boa sobrevém, vem também algo mais doloroso e pior. Eu acabo de ter essa experiência em casa e falo por mim: tive um pouco de prazer enquanto me foi possível estar na presença de meu esposo, uma única noite! E repentinamente ele se afastou de mim, antes mesmo do amanhecer. Agora me vejo sozinha, pois que ele está longe, ele a quem amo acima de tudo que existe. (PLAUTE, 2001, p. 44)
}

\footnotetext{
${ }^{53}$ No original: Satin parua res est uoluptatum in uita atque in aetate agunda, / praequam quod molestum est? Ita cuique comparatum est in aetate hominum; / ita di(ui)s est placitum, uoluptatem ut maeror comes consequatur: / quin incommodi plus malique ilico adsit, boni si optigit quid. / Nam ego id nunc experior domo atque ipsa de meo scio, cui uoluptas / parumper datast, dum uiri mei mihi potestas uidendi fuit /
} 
(...) não há outra explicação para o facto de subitamente se ter apagado a admiração nos olhos dela e de no seu lugar ter surgido uma expressão dolorida, um ar de compassiva lástima, falta saber se de si própria ou do homem que se encontra sentado na sua frente. (...) Maria da Paz não veio aqui para que the dessem explicações acerca de procedimentos sem pés nem cabeça, seja qual for a ponta por onde se lhes pegue, veio para saber quanto terá de pagar para que lhe seja devolvida, se tal é possível ainda, a pequena felicidade em que imaginou haver vivido nos últimos seis meses (HD, 2002, p. 100-101).

No primeiro trecho, percebemos a figura de Alcmena a filosofar e a colocar o seu papel de mulher em questão. Esse questionamento da personagem plautina expressa sua altivez e coragem frente às mulheres da época, demonstrando a autoridade que a personagem possui.

No segundo trecho, por meio da descrição do narrador, há a evocação da figura da de Maria, mãe de Jesus, na apresentação de Maria da Paz: um ar compassivo de lástima, uma expressão dolorida, sem saber sobre si e sobre o homem que está à sua frente. Temos, feitas as devidas ressalvas, a representação paródica da figura de Nossa Senhora das Dores. Mas, como a personagem expressa uma transgressão frente ao modelo onomástico, temos, ao invés de um ser passivo, a figura de uma mulher que luta por suas vontades, por sua felicidade. Assim, nas entrelinhas da interdiscursividade paródica, temos a construção da figura bíblica da mãe de Jesus, somada a uma força e virtude que a aproximam de Alcmena.

Ao deslocar a personagem plautina para um entrecho contemporâneo, Saramago relê certas características da época plautina em suas personagens. Senão vejamos:

\footnotetext{
Maria da Paz, é este o esperançoso e doce nome da mulher que telefonou, não tardará a sair para o seu emprego, e, se Tertuliano Máximo Afonso não lhe fala agora mesmo, a pobre senhora vai ter de viver um dia mais em ânsias, o que, quaisquer que tenham sido os seus erros ou os seus pecados, se em verdade os cometeu, não seria realmente justo. Ou merecido, que foi o termo que ela preferiu usar (HD, 2002, p. 62-63).
}

O trecho citado demonstra perfeitamente como a personagem saramaguiana retoma a Alcmena plautina. Uma mulher que, apesar de sua virtude da correção, está sempre no limiar entre o erro e o pecado. Sem saber se o que lhe acontece é merecido ou não, Maria da Paz, como nos informa o narrador, mantém sua esperança sempre viva, tal qual a matrona plautina, vivendo dias de ânsias e todo o tempo à espera da pessoa amada.

noctem unam modo; atque is repente abiit a me hinc ante lucem. / Sola hic mihi nunc uideor, quia ille hinc abest, / quem ego amo praeter omnis. 
Maria da Paz também possui uma atitude reflexiva e, na maioria das vezes, silenciosa. Essa atitude de Maria da Paz, que apenas aflora nos instantes mais importantes dos episódios decisivos, também é herdada de Alcmena. Na peça de Plauto, ela é a personagem que menos se expressa, mas, quando o faz, é capaz de calar a todos os homens e até de fazer com que o deus do Olimpo se pronuncie e esclareça os fatos para não permitir a continuação do imbróglio. Assim também age Maria da Paz, uma mulher calma e serena, mas que consegue despertar a atenção e a preocupação de todos a sua volta quando decide falar ou tomar alguma atitude mais séria.

Outra "personagem" que se desloca da peça plautina para a narrativa saramaguiana é o Senso Comum ${ }^{54}$. Essa personagem representa, no interior mais profundo da reescrita, uma instância que vai, aos poucos, se desvelando aos olhos do leitor mais atento. Desvelemo-la: lembra-nos Aristóteles que um dos elementos básicos para se compor uma tragédia é o coro, uma das partes quantitativas da tragédia. O coro é uma categoria formal clássica que tem, na tragédia, o papel de trazer a opinião do senso comum sobre o conflito trágico e também o de ser contraponto do herói. Ele representa a coletividade tebana na tragédia grega. Por certo que desaparece em certo momento da história da tragédia, mas reaparece na contemporaneidade por meio da voz. Segundo Pavis, "em sua forma mais geral, o coro é composto por forças (actantes) não individualizadas e frequentemente abstratas, que representam os interesses morais ou políticos superiores" (1999, p. 73). Ou, como expressa o romance,

(...) o papel do senso comum na história de vossa espécie nunca foi além de aconselhar cautela e caldos de galinha, principalmente nos casos em que a estupidez já tomou a palavra e ameaça tomar as rédeas da acção (...) (HD, 2002, p. 156).

Consciente de seu papel, o Senso Comum atua junto a Tertuliano Máximo Afonso sempre que a guarda e o cuidado do professor diminuem. Intervindo várias vezes ao longo da trama ${ }^{55}$, o Senso Comum alerta e vigia o desobediente professor de história, cumprindo, assim, sua função de trazer à baila a opinião comum dentro da tragédia.

\footnotetext{
${ }^{54}$ Para não causar dúvidas em nossa análise, faremos uma diferenciação entre o Senso Comum personagem do romance e o senso comum opinião pública. Para que não confundamos um com outro, usaremos Senso Comum com letras maiúsculas para nos referirmos à personagem do romance e senso comum com letras minúsculas para nos referirmos à opinião da maioria.

${ }^{55}$ Exemplos dessa intervenção podem ser constatados às páginas 109, 121, 222 e 285, dentre outras.
} 
Desta feita, temos, no romance de Saramago, reescrita palimpsesticamente na figura do Senso Comum, a personagem que representa o coro da antiga tragédia grega e que serve como um elemento sibilino e de contraponto dentro da trama. Aos poucos, as linhas do romancista português nos revelam quem é o Senso Comum e quais as suas funções na trama narrativa. Podemos perceber isso no trecho que diz:

Que faço eu se ele se dirigir a mim, Dizes-lhe que extraordinária coincidência, fantástica, curiosa, o que te parecer mais adequado, mas sempre coincidência, e cortas a conversa, Assim sem mais nem menos, Assim sem mais nem menos, Seria uma má-criação, uma indelicadeza, Às vezes é a única maneira de evitar males maiores, não o faças e já sabes o que sucederá, depois de uma palavra virá outra, depois do primeiro encontro haverá segundo e terceiro, às duas por três estarás a contar a tua vida a um desconhecido, já viveste anos bastantes para ter aprendido que com desconhecidos e estranhos todo o cuidado é pouco quando se trata de questões pessoais, e, se queres que te diga, não consigo imaginar nada mais pessoal, nada mais íntimo, que a embrulhada em que pareces estar a ponto de meter-te, É difícil considerar estranha uma pessoa que é igual a mim, Deixa-o continuar a ser o que foi até agora, um desconhecido, Sim, mas estranho nunca poderá ser, Estranhos somos todos, até nós que aqui estamos, A quem te referes, A ti e a mim, ao teu senso comum e a ti mesmo, raramente nos encontramos para conversar, lá muito de tarde em tarde, e, se quisermos ser sinceros, só poucas vezes valeu a pena, Por minha culpa, Também por culpa minha, estamos obrigados por natureza ou condição a seguir caminhos paralelos, mas a distância que nos separa, ou divide, é tão grande que na maior parte dos casos não nos ouvimos um ao outro, Ouço-te agora, Tratou-se de uma emergência, e as emergências aproximam, $O$ que tiver de ser, será, Conheço essa filosofia, costumam chamar-lhe predestinação, fatalismo, fado, mas o que realmente significa é que farás o que te der na real gana, como sempre, Significa que farei aquilo que tiver de fazer, nada menos, Há pessoas para quem é o mesmo aquilo que fizeram e aquilo que pensaram que teriam de fazer, Ao contrário do que julga o senso comum, as coisas da vontade nunca são simples, o que é simples é a indecisão, a incerteza, a irresolução, Quem tal diria, Não te admires, vamos sempre aprendendo, A minha missão acabou, tu farás o que entenderes, Assim é, Portanto, adeus, até outra ocasião, passa bem, Provavelmente até à próxima emergência, Se conseguir chegar a tempo (HD, 2002, p. 31-32 grifos nossos).

A citação nos revela a dimensão sibilina do Senso Comum. Aqui, em uma reestruturação irônica, a personagem 'Senso Comum' faz exatamente o papel de contraponto: ele conversa com o herói e com ele entra em conflito, já que ambos divergem tanto. O nome "Senso Comum" é irônico por si só, pois a função do coro era exatamente a de trazer a opinião do senso comum ao conflito. A personagem, então, ganha o nome de sua função na reescrita com afastamento crítico, ou seja, assume a função de coro deslocado.

Outra pista que o texto libera a seu leitor é a função predestinadora que o Senso Comum possui. Sendo um elemento que serve para alertar o herói, o Senso Comum não poderia expressar uma inverdade dentro da narrativa, senão estaria se contradizendo. Assim, tanto Tertuliano Máximo Afonso quanto o Senso Comum cumprem seus papéis de 
forma correta, um sendo o fatalista e o outro descumprindo, por conta de sua vontade, a condição ditada pelo primeiro.

Mas a função fatalista do Senso Comum é posta em xeque no romance. A própria personagem reconhece, na citação, a superioridade do desejo sobre a razão. Sendo assim, ele se assume como elemento que, apesar de conhecedor da verdade, não possui força de persuasão. Dessa forma, o Senso Comum assume sua impotência diante do destino, da fatalidade. Esse fato evidencia, dentro das disposições deste romance saramaguiano, que a razão lógica nem sempre impera nas decisões, questionando, assim, a racionalidade contemporânea.

Por conta desse questionamento, o deslocamento do coro no romance tem uma função paródica, pois o autor imita um procedimento recorrente na tragédia clássica com o objetivo de questioná-lo, demonstrando que os alicerces antigos foram sobrepostos por uma nova realidade, a da cisão pós-moderna, de que trataremos no próximo capítulo.

A estrutura usual das obras que já superaram o uso do coro tem o Senso Comum expresso geralmente por um coadjuvante, um companheiro do herói. Na obra, a ironia está em colocá-lo sob seu rótulo original de senso comum. Assim, o autor, contrapondo-se ao que recomenda o estilo grego, traz o modelo do coro para colocá-lo em discussão e discordar dele:

(...) não é saudável para o espírito viver de casa e pucarinho com o senso comum, comer com ele à mesa, dormir com ele na cama, levá-lo ao trabalho, pedir-lhe sua aprovação ou consentimento antes de dar um passo, alguma coisa tereis de arriscar por vossa própria conta, A quem te referes, A vocês todos, ao gênero humano (...) (HD, 2002, 2002, p.156).

Saramago ressignifica o senso comum em seu romance. Essa noção materializa-se por meio da soma do coro acrescido de uma espécie de voz consensual (ou a Doxa de que nos fala Roland Barthes: “a Opinião pública, o Espírito majoritário, o consensus pequenoburguês, a Voz do Natural, a Violência do Preconceito" (BARTHES, 1977, p. 53)). O senso comum é uma "cartilha popular", uma síntese da internalização de verdades históricas à semelhança das tábuas da lei oferecidas a Moisés, verdadeiros mandamentos, ordenadores da conduta humana, paródia do código de Hamurabi.

Importa-nos perceber que o Senso Comum mantém um constante diálogo com Tertuliano Máximo Afonso, de modo a exercer sua tradicional função repressiva, fundada em valores que o poder estabelece sorrateiramente e que se tornam inquestionáveis. Ganha estatuto próximo de personagem, mas permanece um domador de comportamentos 
ousados, um amansador de cidadãos, um perpetuador do sistema das ideologias a ele subjacentes.

Aceitar os acontecimentos diários seguindo as orientações do senso comum é achar que a vida seria apenas um caminho limitado, com bifurcações, problemas e emboscadas, mas sem livre arbítrio. Por isso Tertuliano Máximo Afonso não ouve a voz do Senso Comum. Se lembrarmos o coro dos anciões na tragédia grega, ao contradizer a voz do senso comum, o protagonista realiza a mesma atitude que o herói antigo, pois é por meio da negação aos apelos do coro que o herói incorre em hybris. Mas, por outro lado, a personagem do romance está menosprezando a sabedoria da velhice e se contrapondo às tradições antigas, além de enfrentar a falta de liberdade do ser humano e combater o poder centralizador e autoritário da Doxa. Assim, temos um reflexo da atitude discursiva que o romance tem frente ao seu modelo plautino.

Quanto ao Professor de Matemática, sua figura é a representação deslocada da personagem plautina Blefarão. Assim como na peça Blefarão era amigo do protagonista, dando-lhe apoio e tentando ajudá-lo em seus apuros, no romance o Professor de Matemática tem o mesmo tipo de laço afetivo com Tertuliano Máximo Afonso, e tenta ajudá-lo a sair de sua depressão por meio da indicação de um filme de segunda categoria. Este fato torna essa personagem o causador do nascimento do conflito narrativo, já que é ele quem indica ao amigo que assista Quem porfia mata caça, filme que dará origem às preocupações ônticas e existenciais de Tertuliano Máximo Afonso. Sua função na trama narrativa é a de ser uma personagem ambígua, que ora sabe de tudo, tal qual Blefarão sabia do que havia acontecido na guerra contra os Teleboas, ora desconhece tudo que se passa a sua volta, como um ingênuo que simplesmente indica o filme a seu amigo para, inocentemente, ajudá-lo, sem nenhuma intenção de que este veja um ator parecido consigo, assim como ocorre com Blefarão, que não sabe quem é o verdadeiro Anfitrião. Seu acréscimo no romance opera como elemento de renovação, que suscita o primevo no atual.

A vizinha do andar de cima é outra figura que se desloca da peça plautina para o romance de Saramago. Sua figura expressa as mesmas funções da escrava Brômia na peça plautina. Na peça, Brômia quase não aparece, servindo apenas para avisar a Anfitrião sobre o nascimento milagroso de seu filho divino; a vizinha do andar de cima, em $O$ Homem Duplicado, apenas vinha limpar a casa de Tertuliano Máximo Afonso. Como Brômia, ela é igualmente reduzida a segundo plano, aparecendo por volta de doze vezes na narrativa, sempre a fazer a limpeza ou a ajudar a personagem principal nos cuidados da casa. Sua 
função, tal qual a de Brômia, é a de empregada. Deslocada de lá para cá, a função da vizinha da cima na trama servirá apenas, tal qual a de seu protótipo, para complementar a narrativa de forma renovada.

Por fim, Tertuliano Máximo Afonso e seu duplo António Claro/Daniel Santa-Clara são as últimas personagens deslocadas do Amphytruo plautino. Colocamos aqui os dois juntos, pois pensamos não ser possível analisar uma personagem sem pensar imediatamente na outra. Os dois são partes constitutivas de uma terceira personagem que vai sendo moldada nas linhas e entrelinhas do romance, o Sr. Tertuliano Máximo Afonso/ António Claro/Daniel Santa-Clara: um ser que assume a vida de um, mas com a subjetividade do outro dentro uma terceira realidade, a de ser um e outro ao mesmo tempo.

Reflitamos primeiro sobre a relação que a dupla estabelece com a peça plautina. Se, em Plauto, temos dois pares de duplos que, por conta de suas aparências, causam enormes quiproquós, no texto de Saramago temos, a priori ${ }^{56}$, apenas um par. Porém, cada um desses pares é, em verdade, um ser duplo, que possui dois nomes ou duas personalidades, que expressam, por outros meios, aquele segundo par de duplos da peça plautina.

Assim, eles podem expressar, num primeiro momento, o deslocamento da situação de duplicação pela qual passou Anfitrião. Temos, portanto, uma relação intertextual alusiva, já que a estrutura da peça plautina é deslocada para o romance saramaguiano; mas identificamos ainda uma relação interdiscursiva, pois a alusão também acontece com relação à temática que a segunda obra incorpora da primeira.

Além dessa duplicação, os dois duplos também se envolvem em um grande quiproquó, pois acabam trocando de identidade e dormindo um com a mulher do outro. Essa troca simboliza a retomada da ideia de troca de marido tematizada no Amphytruo e permite o acréscimo da dupla troca, fato que inexistia na peça plautina e que Saramago reinventa em seu romance:

Quando o António Claro entrar amanhã em casa vai ter a maior das dificuldades
para explicar à mulher como foi que conseguiu dormir com ela e ao mesmo
tempo estar a trabalhar fora da cidade, Não imaginei que fosses capaz de tanto, é
um plano absolutamente diabólico, Humano, meu caro, simplesmente humano, o
diabo não faz planos, aliás, se os homens fossem bons, ele nem existiria, E
amanhã, Arranjarei um pretexto para sair cedo, Esse livro, Não sei, talvez o
deixe ficar aqui como recordação. O elevador parou no quinto andar, Tertuliano
Máximo Afonso perguntou, Vens comigo, Sou o senso comum, aí dentro não há
lugar para mim, Então, até à vista, Duvido (HD, 2002, p. 285-86).

\footnotetext{
${ }^{56}$ Fazemos essa ressalva, pois, como já vimos, Maria da Paz e Helena podem ser um outro par de duplos, que não podemos perceber tão claramente quanto Tertuliano Máximo Afonso e António Claro/Daniel SantaClara.
} 
$\mathrm{Na}$ conversa entre o Senso Comum e Tertuliano Máximo Afonso, percebemos como sua troca se evidencia também como um ato de vingança para com seu duplo, o que corrobora o deslocamento do fato, da peça para o romance.

O teatro é o espaço de representação da tragicomédia plautina; nele, o escritor latino reconstrói a cidade de Tebas, das grandes histórias mitológicas, dos deuses e heróis. Já o espaço da narrativa saramaguiana é qualquer grande cidade de nossa época, na qual os seres humanos, envolvidos no universo globalizado, onde tudo é massificado, inclusive as relações pessoais, perdem a sua individualidade.

Assim, a disposição do cenário no começo do Amphytruo já é suficiente para percebermos o alto e o baixo que caracterizam a obra. A peça começa com Mercúrio em um lugar acima de sua plateia, a dialogar e a antecipar os fatos que ocorrerão na peça. $\mathrm{Na}$ cena seguinte, o espaço representado é o da casa de Anfitrião. Nesses cenários ressaltamos a coexistência de elementos que se opõem: o das regiões do Olimpo, onde habita Júpiter, e o terreno, representado pela casa de Anfitrião e pela área desta.

Temos, disseminado pela peça, esse jogo entre os espaços celestes e terrenos, sendo que o terreno será o local das ações, sejam elas sexuais (relacionamento entre Júpiter e Alcmena), de revelações (aparecimento de Júpiter epifânico a Anfitrião), o lugar do conflito (briga entre Anfitrião e Alcmena, briga entre Sósia e Mercúrio, tensão entre os dois Anfitriões) etc.

Esse espaço é, guardadas suas devidas proporções, semelhante à praça pública carnavalesca de que nos fala Bakhtin. A praça pública é "o principal palco das ações carnavalescas”, uma vez que "o carnaval é, por sua própria ideia, público e universal, pois todos devem participar do contato familiar" (BAKHTIN, 1997, p. 131). Estas observações referem-se ao carnaval enquanto festividade, mas podem ser ampliadas e estendidas à leitura de espaços ficcionais que permitam e estimulem a interação plena entre as personagens, como aparece fortemente evidenciado no teatro de Plauto.

Já em O Homem Duplicado, a oposição entre o espaço sagrado e o profano dá-se pela representação da escola e do cinema. A escola é o lugar do tradicional, das certezas e das verdades, espaço que representa o sagrado. Já o cinema é o lugar da representação, da farsa e da mentira, um espaço que representa o profano. Trasladada para o romance, essa noção de espaços celestes e profanos adquire novo tom, passando por um deslocamento que os obriga a serem relidos por Saramago em nossa sociedade pós-moderna. É essa 
releitura que configura o deslocar do espaço celeste para a escola e do espaço terreno para o cinema.

Esta separação dicotômica entre os espaços é, por si só, conflitiva e pode ser vista como o viés da ação dramática, no qual se desenvolverá o enredo de cada uma das duas narrativas.

Outro elemento deslocado da peça plautina para o romance de Saramago está na questão do disfarce. $\mathrm{O}$ traje, na peça plautina, servia para que a simulação fosse perfeita (Cf. PLAUTE, 2001, p. 116-117) - tanto que uma mudança de traje correspondia à própria metamorfose de Júpiter em Anfitrião. Mercúrio vai deixar de lado seus chapéu e sandálias aladas, juntamente com seu habitual caduceu para vestir-se com a túnica curta, usada por escravos; Júpiter, por sua vez, prescinde das insígnias divinas para vestir-se com a pele do general tebano. $\mathrm{O}$ resultado obtido é tão enganador que se estabelece uma conivência entre a cena e o público: um sinal discreto, que as outras personagens não saberão detectar, será a marca que distinguirá duplicado de original: uma pena no chapéu identificará sempre Mercúrio e uma corrente de ouro sob a aba do capacete, o anfitrião divino (Cf. PLAUTE, 2001, p. 142-147).

Em O Homem Duplicado, essa questão da diferenciação entre Tertuliano Máximo Afonso e António Claro/Daniel Santa-Clara também se dá por meio de disfarces. No entanto, se, em Plauto, o disfarce era apenas o de uma pena ou de uma corrente de ouro, em Saramago essa ação se multiplicará em diversas formas, das quais as mais importantes e usadas são a barba postiça e a aliança. A escolha da barba é feita depois de uma longa reflexão sobre a necessidade e utilidade dela ou não, como podemos perceber nos trechos a seguir:

O recurso ao disfarce, aos clássicos postiços de barba, bigode e peruca, além de superlativamente ridículo, seria mais do que estúpido, iria fazê-lo sentir-se como um mau intérprete de melodrama oitocentista, como um pai nobre ou um cínico de quarto acto, e, como sempre havia temido que a vida se lembrasse dele para alvo das partidas de mau gosto em que não é raro esmerar-se, tinha a certeza de que o bigode e a barba lhe cairiam no justo momento em que perguntasse pelo senhor Daniel Santa-Clara e de que a pessoa ínterrogada desataria a rir e chamaria ao divertimento os colegas, Boa piada, boa piada, venham cá ver o senhor Daniel Santa-Clara a perguntar por si mesmo (HD, 2002, p. 20, grifos nossos)

O que finalmente nos deve tranquilizar, aclarados já os passos a dar, é a certeza de que Tertuliano Máximo Afonso poderá deslocar-se sem nenhum receio à loja dos disfarces e enfeites, escolher e adquirir o modelo de barba que melhor condiga com a sua cara, observando, no entanto, a cláusula incondicional de que uma barbica do género geralmente conhecido por passa-piolho, mesmo que o transformasse num árbitro de elegâncias, teria de ser firmemente rejeitada, sem regateio nem cedência às tentações de uma redução de preço, pois o desenho de 
orelha a orelha e a relativa curteza do pêlo, sem falar da nudez do lábio superior, deixariam pouco menos que à luz crua do dia as feições que justamente se pretende levar ocultas. Por ordem inversa de razões, ou seja, porque iria chamar demasiado a atenção dos curiosos, também deverá ser excluída qualquer espécie de barba longa, mesmo não pertencendo ao tipo apostólico. $\mathrm{O}$ conveniente será, portanto, uma barba cheia, bastamente povoada, tirando, porém, mais para o lado do curto que para o lado do comprido. (...) Quando pela primeira vez olhou a sua nova fisionomia sentiu um fortissimo impacte interior, aquela intima e insistente palpitação nervosa do plexo solar que tão bem conhece, porém, o choque não tinha sido o resultado, simplesmente, de se ver distinto do que era antes, mas sim, e isso é muito mais interessante se tivermos em conta a peculiar situação em que tem vivido nos últimos tempos, uma consciência também distinta de si mesmo, como se, finalmente, tivesse acabado de encontrar-se com a sua própria e autêntica identidade. Era como se, por aparecer diferente, se tivesse tomado mais ele mesmo. Tão intensa foi a impressão do choque, tão extrema a sensação de força que dele se apoderou, tão exaltada a incompreensível alegria que o invadiu, que uma necessidade angustiosa de conservar a imagem ofez sair de casa, usando de todas as cautelas para não ser visto, e dirigir-se a um estabelecimento fotográfico longe do bairro onde vivia, para que lhe tirassem o retrato (HD, 2002, p. 163-65, grifos nossos).

Se, no primeiro excerto, temos a insegurança de Tertuliano Máximo Afonso em saber se vai ou não disfarçar-se por meio de uma barba, a indecisão por qual tipo de barba escolher e o medo em se disfarçar, no segundo trecho temos a personagem sendo contaminada por seu disfarce. $\mathrm{O}$ apetrecho, utilizado pelo protagonista no rosto, servia-lhe para não ser confundido com o ator enquanto o professor percorria os mesmos espaços de António Claro/Daniel Santa-Clara, e também fazia-o vivenciar outra identidade que não a sua própria.

$\mathrm{O}$ artifício de se travestir em outro para vivenciar diferentes formas identitárias revela uma aproximação com a atividade profissional de António Claro/Daniel SantaClara. O ator vive diariamente utilizando-se de máscaras para dar vida às suas personagens. Usar a máscara tem o significado de sair de si, entrar no desconhecido, habitar o inabitável até então, mas uma experiência provisória na vida dos atores. Isso porque a máscara não é fixa, ela revela o talento do ator em poder se transformar em diferentes personagens em sua vivência de múltiplas identidades nos palcos, no cinema e/ou televisão.

Para o professor de História, a barba é um escudo; com o disfarce procura se defender daquilo que é estranho e, ao mesmo tempo, familiar: sua imagem física em outra pessoa, seu duplicado. Neste caso, ressaltamos a primeira ocorrência de Unheimlich da trama saramaguiana. Se, como já dissemos, o Unheimlich é algo familiar e, ao mesmo tempo, estranho e assustador, o professor de história, ao identificar uma personagem com aparência igual a sua, estranha o fato por isso ser cientificamente impossivel no nosso 
universo de possibilidades; mas, ao mesmo tempo, a personagem sente algo familiar, ja que a imagem do rosto que vê em frente à televisao é semelhante a sua, algo que ele está acostumado a ver todos os dias.

Assim, ao se disfarçar tal como Júpiter para sondar a vida do outro, Tertuliano Máximo Afonso acaba incorrendo na vontade de ser um outro, como está expresso na sua tomada de decisão em visitar urgentemente um estabelecimento fotográfico para guardar seu retrato com a face disfarçada. Mais do que se proteger ou tentar se diferenciar de seu duplo, o professor de história busca se reencontrar, criar uma nova imagem para si.

Somado ao disfarce da barba, temos também outro elemento que marca a diferença entre os dois duplicados: o sinal deixado pela aliança de ouro que António Claro/Daniel Santa-Clara usava no dedo anelar esquerdo. Se, em Plauto, Júpiter rouba as formas de Anfitrião e engana a esposa deste, em Saramago, António Claro/Daniel Santa-Clara usa a mesma estratégia para enganar Maria da Paz, namorada de Tertuliano Máximo Afonso, e com ela se relacionar sexualmente ${ }^{57}$.

A aliança, marca do casamento do ator com sua mulher, servirá como elemento de diferenciação entre ele e Tertuliano Máximo Afonso. Porém, se, na peça plautina, é somente o público quem sabe reconhecer a diferença entre os sósias e seus pares verdadeiros, na narrativa de Saramago é a personagem Maria da Paz quem descobre a diferença entre os duplicados. Ao sair com António Claro/Daniel Santa-Clara pensando que este é Tertuliano Máximo Afonso, a personagem percebe o sutil detalhe, o que desencadeará o clímax da narrativa e levará, por deslocamento, a tragicomédia plautina a ganhar foros de tragédia:

O dedo anelar mostrava a marca circular e esbranquiçada que as alianças longamente usadas deixam na pele. Maria da Paz estremeceu, julgou que estava a ver mal, que estava a sonhar o pior dos pesadelos, este homem igual a Tertuliano Máximo Afonso não é Tertuliano Máximo Afonso, Tertuliano Máximo Afonso não usa anéis desde que se divorciou, a marca do seu dedo há muito tempo que se desvaneceu. O homem dormia placidamente. Maria da Paz deslizou com mil cautelas para fora da cama, recolheu as suas roupas dispersas e saiu do quarto. Vestiu-se na sala de entrada, ainda demasiado aturdida para pensar com lucidez, impotente para encontrar uma resposta à pergunta que lhe dava voltas na cabeça, Estarei louca. Que o homem que a tinha trazido aqui e com quem passara a noite não era Tertuliano Máximo Afonso, disso tinha completa certeza, mas, se não era ele, quem seria então, e como é possível que neste mundo existam duas pessoas exactamente iguais, ao ponto de em tudo se confundirem, no corpo, nos gestos, na voz. Pouco a pouco, como quem vai procurando e descobrindo as peças certas para o puzzle, começou a relacionar

\footnotetext{
${ }^{57}$ Outras relações dialógicas, mas que não cabem nos quatro elementos aqui destacados, serão apresentadas no próximo capítulo.
} 
acontecimentos e acções, recordou palavras equívocas que havia escutado a Tertuliano Máximo Afonso, as suas evasivas, a carta recebida da produtora de cinema, a promessa que ele fizera de que um dia lhe contaria tudo. Não podia ir mais longe, continuaria a não saber quem era este homem, salvo se ele próprio o dissesse. A voz de Tertuliano Máximo Afonso ouviu-se lá de dentro, Maria da Paz. Ela não respondeu, e a voz insistiu, insinuante, cariciosa, Ainda é cedo, vem para a cama. Ela levantou-se da cadeira onde se havia deixado cair e dirigiu-se ao quarto. Não passou da entrada. Ele disse, Que ideia foi essa de te vestires, vá, tira a roupa e salta para aqui, a festa ainda não acabou, Quem é você, perguntou Maria da Paz, e antes que ele respondesse, De que anel é a arca que tem no dedo. António Claro olhou a mão e disse, Ah, isto, Sim, isso, você não é o Tertuliano, Não sou, de facto não sou o Tertuliano, Quem é, então (...) (HD, 2002, p. 31213).

O trecho revela em detalhes como a descoberta faz com que a troca de identidades processe uma mudança na trama, pois, de inocente, Maria da Paz passa a enganada que se revolta com o fato, o que culminará com sua morte e a morte de António Claro/Daniel Santa-Clara. A conclusão a que podemos chegar após essa transformação é que esses dois duplos (o pseudo-Anfitrião em Plauto e Tertuliano Máximo Afonso e António Claro/ Daniel Santa-Clara), em Saramago, além de se transformarem na personalidade alheia, também comprometem, reciprocamente, a relação amorosa um do outro; e essa relação amorosa deslocada é que gerará o conflito das duas narrativas.

Por fim, um último deslocamento está na questão do ciúme, que é deslocado da vida divina (em Plauto) para a vida humana (em José Saramago). Se, na peça de Plauto, Anfitrião se recusa a assumir sua mulher porque esta o traiu e só a aceita quando o deus do Olimpo vem em socorro de Alcmena, na narrativa saramaguiana, Tertuliano Máximo Afonso até se sente enciumado quando António Claro/Daniel Santa-Clara propõe dormir com Maria da Paz, mas logo cede em razão de seu medo do outro.

Assim, por motivos diferentes devido ao deslocamento sofrido, as duas personagens aceitam a traição que sofrem, mas aceitam a evidência de que o outro dormiu (em Plauto) ou dormirá (em Saramago) com a esposa.

Dessa forma, retomando o mito e, ao mesmo tempo renovando-o, Saramago instaura o distanciamento crítico por meio de expedientes intertextuais.

\subsection{As faces do caos}

O Homem Duplicado alcança sua originalidade por possibilitar ao leitor prescindir do conhecimento ou mesmo do exame detalhado de seus elementos intertextuais. Como uma espécie de corpo, o romance apresenta diversas peles, cada uma mais profunda que a 
outra e que, conforme as formos descobrindo, novos horizontes interpretativos nos são revelados.

É inegável que o leitor poderá realizar uma perfeita leitura e análise de $O$ Homem Duplicado sem o recurso à intertextualidade. Entretanto o conhecimento do Amphytruo e das outras fontes que dialogam com o romance possibilita ao estudioso penetrar, de forma mais profunda, na análise do texto e dele extrair uma significação nova e mais consistente. A atmosfera ambígua resultante de uma forte carga simbólica e sugestiva é bastante acentuada em $O$ Homem Duplicado, além da marca narrativa que é indicativo inconfundível próprio escritor português, o que faz com que o livro já traga um valor artístico por si só. Por esse meio, conhecer os possíveis diálogos e formas de comunicação que o romance estabelece com outros textos torna sua leitura muito mais rica e prazerosa. Sendo assim, ter o conhecimento das relações palimpsésticas que o texto cria irá sempre somar na interpretação do mesmo, mas o desconhecimento delas não prejudica o contexto como um todo.

Ainda abordando as relações presentes no romance português em análise, é possível ainda levantarmos uma última questão concernente às personagens e que se dá no nível alegórico do romance. Nesse nível, Saramago retomará um tema caro às suas narrativas: o questionamento da História. Se penetrarmos na leitura alegórica de O Homem Duplicado, notaremos que o autor se vale de um jogo metalinguístico, usando os dois principais duplos como a personificação de dois conceitos - Ficção e História - com o intuito de problematizá-los.

Tertuliano Máximo Afonso, professor de história e indivíduo organizado, que mantém a ordem cronológica até para ver filmes, é a personagem que representa a História. Já António Claro/Daniel Santa-Clara, ator, mestre do mascaramento, da invenção e da atuação, prefigura a representação do Ficcional.

Visto por essa faceta, o livro todo é uma discussão metalinguística a respeito da precedência da Ficção sobre a História ou vice-versa. Temos, no nível intertextual, um diálogo entre duas obras distintas e, no nível interdiscursivo, uma discussão há muito presente nos textos de Saramago, o eterno "conflito" entre História e Ficção. Na narrativa, o escritor questiona a veracidade da História, pois, segundo ele, ela é um saber narrativo e, enquanto narrativa, cria um fato histórico, já que o acontecimento passou e é irrecuperável. Dito de outro modo: outra, sem surpresa, sempre a fazem, ao passo que o romancista, de quem se 
conta que não faça mais que a sua ficçãozinha de cada dia, acaba por surpreender, e pelos vistos muitos, se guiou essa ficção pelos caminhos da história como se leva uma pequena lanterna de Mão que vai iluminando os cantos e os recantos do tempo com simpatia indulgente e irónica compaixão (CL1, 1997a, p. 113).

A imprecisão dos limites entre as duas formas de conhecimento permite que Saramago construa um romance no qual as fronteiras se interpenetram. Afirma Teresa Cristina que, "se a História tende para o literário, não é menos evidente que a ficção, de modo geral, sonhe penetrar nos domínios seguros da verdade histórica" (CERDEIRA, 1989, p. 26). Assim, Saramago está acostumado a escrever romances em que a “(...) História se quer ficção, e não apenas (sic) uma ficção que se compactua com a História (...)" (CERDEIRA 1989, p.26). Dessa forma, o autor problematiza, em seu romance, a certeza dos fatos e ausência de imaginação no que é contado pela História.

Retomando a velha dicotomia história e ficção, o romance de Saramago fabula um conflito entre dois personagens, cada um representando um dos polos dicotômicos. O conflito da narrativa, partindo deste ponto de vista, tem início quando as personagens se conhecem e têm a necessidade de saber quem nasceu primeiro e, portanto, qual tem a primogenitura e a primazia sobre o outro. $\mathrm{O}$ discurso romanesco aponta para um processo filosófico muito mais complexo que se revela nas entrelinhas do discurso: quem, afinal, é mais importante, a História ou a Ficção? Há "uma espécie de consciência de primogenitura que neste momento se está rebelando contra a ameaça, como se um ambicioso irmão bastardo aí viesse para apear o trono" (HD, 2002, p. 175). A importância desse dado é tão grande que, já no primeiro encontro, eles querem ver os documentos um do outro para saber quem nasceu primeiro. Descobrem que nasceram no mesmo ano, mês e dia, restando saber a hora em que nasceram. Tertuliano Máximo Afonso diz seu horário de nascimento primeiro, e, assim não sabemos se António Claro/Daniel Santa-Clara inventou ou não sua data de nascença, tendo em vista que este personagem mascara fatos e verdades.

Partindo dessa suposição, podemos analisar cada uma das duas personagens a partir desse pressuposto. António Claro/Daniel Santa-Clara possui um papel secundário no cinema, mas vem ganhando espaço, assim como a Ficção tem seu espaço como área de possibilidade de conhecimento. Ele vive da arte de representar ou, nas palavras de Aristóteles, sobrevive "daquilo que poderia ter acontecido".

Vivendo de altos e baixos, de mudanças bruscas e de posturas antagônicas, António Claro/Daniel Santa-Clara difere, em posturas e atitudes, de seu duplo Tertuliano Máximo Afonso: ele gosta de encenar. Tanto que obriga o professor de história a deixá-lo passar 
uma noite com Maria da Paz, fazendo-se passar pelo outro. Disso podemos inferir que a Arte, eventualmente, gosta de se fazer passar por História, gosta de tomar o seu lugar. Às vezes apenas para falseá-la, mas também para revelar uma outra faceta da verdade, como ciência de construção desse todo que é a realidade. Assim erige a Ficção um lugar seu, que lhe cabe por direito.

Para diferenciar Ficção de História, só se formos muito atentos, poderemos perceber-lhes as diferenças estruturais. Assim como, por exemplo, a marca da aliança no dedo fez com que Maria da Paz descobrisse o engodo, é por pequenas marcas que a Arte se revela enquanto construção, e não como expoente único da verdade. Dessa forma, é sempre com cautela que podemos perceber que não é História, mas criação artística se fazendo passar por História.

O uso de um nome artístico é outro indício da dissimulação por parte do ficcional em António Claro/Daniel Santa-Clara. Quase tudo no ator é ficção, até seu próprio nome é inventado. No entanto tem personalidade própriaEl e prefere que seu nome artístico seja considerado um heterônimo, ao invés de pseudônimo (cf. HD, 2002, 155). Isso, como já nos ensinou a lição literária de Fernando Pessoa, implica conceitualmente a invenção de outro ser com características próprias, o que permite à ficção e à realidade caminharem lado a lado.

Já Tertuliano Máximo Afonso afirma ter um emprego fixo e uma profissão honrada, que crê ser mais nobre, mas menos prestigiada que a de António Claro/Daniel Santa-Clara. Tal pensamento do professor de história pode ser visto no fragmento a seguir:

\begin{abstract}
$\mathrm{Eu}$, ao menos sou professor de história, murmurou. Uma declaração assim, que acintosamente tinha pretendido determinar e enfatizar a sua superioridade, não apenas profissional, mas também moral e social, em relação à insignificância do papel da personagem. (HD, 2002, p.89).
\end{abstract}

Assim, através da inventividade de Saramago, Ficção e História se aproximam pelos meandros da criação. Precisamos notar ainda que, apesar de ser romancista, Saramago elege como protagonista de sua trama uma personagem que se estabelece pelo lado do factual. Quereria Saramago demonstrar com isso a superioridade da História em relação à Arte?

Acreditamos que não. Em verdade, pensamos que o autor desconstrói a noção de superioridade entre as duas formas de conhecimento, entrelaçando-as por meio de um distanciamento narrativo, até alcançar de seus leitores uma visão diferenciada dessa mesma relação. Não há mais superioridade ou inferioridade entre elas. O que temos agora é um 
embaralhamento das duas ordens de conhecimento até chegar ao seu amálgama. Um perfeito exemplo desse entrecruzamento é o trecho a seguir, em que a personagem da História se traveste de personagem artística:

(...) o pior defeito deste homem, pelo menos desde que o conhecemos, tem sido o excesso de imaginação, na verdade ninguém diria que se trata de um professor de História a quem só os factos deveriam interessar, só por ter visto pelas costas a mulher que acaba de passar já o temos aqui a falsear identidades, ainda por cima de uma pessoa a quem não conhece, (...) Justiça deve ser feito no entanto a Tertuliano Máximo Afonso porque apesar de sua tendência para o desvairo imaginativo, ainda consegue, em momentos decisivos, sobrepor-lhe uma frieza de cálculo que faria empalidecer de ciúme profissional o mais encalecido dos especuladores da bolsa (HD, 2002, p.173).

Ao tomarem o lugar um do outro, parece que as personagens ficam mais excitadas, mais contentes com sua nova posição, por isso o tratamento dispensado pelos duplos à mulher do outro é tão diferente do que dispensam à sua própria. Tertuliano Máximo Afonso aprecia mais a esposa de António Claro/Daniel Santa-Clara, enquanto este gosta mais da namorada do professor de história. Por fim, Tertuliano Máximo Afonso toma o lugar de António Claro/Daniel Santa-Clara definitivamente, já que este morre. Isso simboliza o momento contemporâneo, em que temos uma aliança entre fícção e apropriação dos acontecimentos e personagens históricas. Ou, segundo a concepção e Hutcheon, temos a história apresentada dentro da ficção, uma tomada ficcional do espaço dito factual. Assim, a História sobrevive, mas disfarçada em Ficção. A título de ilustração, poderíamos ver o discurso seguinte:

\begin{abstract}
A diferença não é grande, A nossa colega de Literatura diria que é, pelo contrário, enorme, e ela entende dessas coisas, creio que subtilezas e matizes a literatura é quase como a matemática, Já eu, pobre de mim, pertenço à área da História, onde os matizes e as subtilezas não existem, Existiriam se a História pudesse ser, digamos assim, o retrato da vida, Estou a estranhá-lo, não é próprio de si ser tão convencionalmente retórico, Tem toda a razão, em tal caso a História não seria a vida, apenas um dos retratos possíveis dela, parecidos, sim, mas nunca iguais (HD, 2002, p. 145-146).
\end{abstract}

Logo, Tertuliano Máximo Afonso e António Claro/Daniel Santa-Clara têm representantes alegóricos no romance, apresentam um falseamento: História e Arte são ficções construídas pelo escritor Saramago. O autor faz-nos crer que pensa a História como uma espécie de reverso da Arte. Parece-nos revelar que o relato histórico, até certo ponto, segue os fatos, mas é cheio de surpresas inventadas. Para fazer com que esse discurso factual seja revisto pelo olhar ficcional, nada melhor que se valer da paródia, já que, conforme Hutcheon, (1991, p. 28), a paródia, “paradoxalmente, incorpora e desafia aquilo a que parodia. Ela também obriga a uma reconsideração da ideia de origem ou 
originalidade", estimulando o leitor a reavaliar suas opiniões e atitudes frente ao objeto parodiado.

O Homem Duplicado se caracteriza por uma busca de novas possibilidades romanescas, concebendo o fazer literário como essencialmente invenção e criação. Nele, há o forjamento de uma "visão" diferenciada, à margem da oficial ou real, da questão da História e da Verdade. Essa "outra" visão pretende levar o leitor a questionar as supostas verdades veiculadas pela ideologia dominante e pôr em constante dúvida o mundo em que vivemos, combatendo a imposição de uma ideia absoluta, seja ela moral, religiosa ou política. Aqui se explica o porquê do retorno ao tema já há muito discutido pelo escritor: combater o monologismo da História enquanto verdade absoluta; encontrar uma outra forma, mesmo que menos científica e mais ficcional, de ver o ser humano e suas labirínticas vidas.

Podemos, então, inferir que o autor de O Homem Duplicado representa a importância da arte literária: coloca um historiador - representante do Real, do concreto em uma busca obsessiva pelo ator, seu duplo - representante da Ficção. O contato entre as duas personagens permite que reorganizemos nossas bases interpretativas sobre o que seja história e/ou ficção.

Em suma, a ação narrativa do escritor português é pautada em semelhanças e dessemelhanças em relação a seu protótipo latino. Os expedientes de que nos valemos para analisá-las nos permitem afirmar que, se o romance renova e se distancia criticamente de seu protótipo, a base da fábula, mesmo deslocada no tempo e no contexto, permanece a mesma. O Amphytruo reescrito em $O$ Homem Duplicado é uma materialização da época em que vivemos. Ora, se, por antonomásia, o vocábulo anfitrião se tornou "todo aquele que bem recebe em sua casa", também o protagonista de $O$ Homem Duplicado pode ser, guardadas as devidas proporções, o representante especular de qualquer indivíduo deste atormentado início de século XXI.

Importa notarmos, por fim, que o sujeito atormentado do século XXI é um ser fragmentado, no qual a conclusão inexiste. Ele é aberto, sempre posto em xeque, caótico por natureza. Este homem do limiar, que transita constantemente entre um lugar e outro, não é mais isto ou aquilo, ele é isto e aquilo ao meso tempo. É essa multifacetada face, em contraposição ao sujeito uno e monolítico de Plauto, que tentaremos interpretar a seguir. 


\title{
CAPÍTULO IV
}

\section{Ordem/Caos: elementos para um remate técnico da arte vivida (ou da vida estetizada)}

\author{
Uma das pessoas vai riscando no chão uns traços \\ enigmáticos que tanto podem ser um retrato como uma \\ declaração de amor ou a palavra que faltasse inventar. \\ (A93, p. 9). \\ “...connaître l'autre et soi est une seule et même chose" \\ $(\text { TODOROV })^{58}$.
}

O tempo que a sociedade de hoje projeta se constitui por meio de um processo em que o virtual e o individual parecem ter se tornado os únicos caminhos para o ser humano. Essa sociedade a qual chamamos - em consonância com Bauman - de liquida é individual e fragmentaria por opção de seus próprios membros. Estes cobram um mundo acabado e sem as mazelas contemporâneas; cobram uma realidade surgida num passe de mágica. Não existindo essa realidade cobrada, o discurso social torna-se vazio e sem sentido, já que os sentidos preexistentes que a sociedade condena são, por ela mesma, alimentados.

Este tempo em que vivemos dá-nos azo a reflexões que muitas vezes se direciona pra a questão da identidade e da alteridade. Essa reflexão, de uma forma ou de outra, estão presentes dentro do contexto artístico das duas obras analisadas até agora. Tanto $O$ Anfitrião quanto $O$ Homem Duplicado temos como núcleo base de suas escritas justamente o processo de tomada de consciência de si, mas de forma diferente, conforme o tempo em que elas se localizam e relacionadas ao tempo em que tais livros foram escritos.

Partindo desse tema motivador para nossas reflexões, notamos que os livros de Plauto e Saramago permitem a seus leitores, além de diversas questões, uma reflexão sobre a questão da identidade dos sujeitos de suas épocas. Partindo desse pressuposto, nossa tarefa neste momento será ver como se delineia a identidade das personagens das obras por meio do conceito de alteridade - foi condutor deste capítulo -, extraindo dessa delineação os elementos interpretativos plausíveis para cada uma dos livros analisados.

Podemos notar que, por serem escritos em períodos e épocas diferentes, cada uma das obras expressa modelos condizentes com suas épocas. $\mathrm{Na}$ Antiguidade (aqui representada pelo Amphitruo plautino) há uma unidade primitiva em que o eu e o outro,

\footnotetext{
58 "Conhecer ao outro e a si mesmo é uma e a mesma coisa." Tradução livre nossa.
} 
apesar do embate, em que não entram em um conflito intrínseco - ou heterogêneo - de identidade entre os duplicados. Apesar do embate, o conflito entre os sujeitos do texto plautino resolvem seu conflito, ajustando suas necessidades por meio interferência divina. Já O Homem Duplicado retoma o tema plautino no qual o conflito de identidade é conflitivo e não apresenta solução tal qual o de seu protótipo. Há um processo conflitivo no qual o monolitismo não se sustém.

Tanto em uma quanto em outra narrativa, é por meio do tema do duplo que a questão identitária desabrocha; a presença do outro desestabiliza o eu fazendo com que o mesmo entre em crise. A estabilidade identitária, que encontra seu equilíbrio no outro, fica desequilibrada porque o eu, ao invés de aceitar o outro em sua alteridade, o nega. A cisão da personalidade originaria na figura do duplo cinde a a personalidade dos sujeitos dos livros de Plauto e Saramago.

Partindo desse pressuposto, retomamos os conceitos de duplo explicitados em nosso primeiro capítulo para utilizá-los em nossa análise aqui proposta. Os elementos que analisamos, tanto em Plauto (capítulo II) quanto em Saramago (capítulo III), retornam para que possamos compor o mosaico interpretativo da questão identitária nos dois escritores em questão.

Etimologicamente, o vocábulo identidade nos remete a idem, que é proveniente do latim e significa "o mesmo, a mesma coisa" (SARAIVA, 2006, p. 568). Mas, pelos estudos realizados ao longo do tempo sabemos que, na verdade, possui outros aspectos que ultrapassam a definição etimológica dicionarizada por Saraiva. A identidade não é algo inato, que permanece sendo sempre a mesma coisa como expressa Saraiva, mas sim um processo, na qual há vários estágios de construção, que se realizam por meio do contato com o outro - individual e social.

A questão da identidade remete a uma dicotomia na constituição da identidade: a do igual e do diferente. $\mathrm{O}$ conceito de identidade evoca tanto a qualidade do que é idêntico, igual, como a noção de um conjunto de caracteres que fazem reconhecer um indivíduo como diferente dos demais. Como diz Jacques Rancière, "a pluralidade humana tem o duplo aspecto da igualdade e da diferença" (2005, p.164).

Já para o olhar dos estudos culturais, a identidade 
à sua consciência de ser limitado e diferenciado por um corpo próprio (MEZAN, 1988, p. 256).

Ao penetrar o espaço literário, a questão da identidade é pautada pela intersecção de diversas áreas do conhecimento, no qual os contornos nem sempre são bem definidos, sendo assim, dentro da realidade romanesca a questão identitária encontra na temática do duplo uma perfeita unidade, pois à medida que avança o enredo romanesco, os dois aportes criam um mutável mosaico - ou ainda um calidoscópio - que assume diferentes formas conforme se combinam. A questão identitária, mediada pela tópica da duplicidade, recupera e/ou repete situações passíveis de serem interpretadas. Situações estas que permitem que possamos refletir sobre características da sociedade que as mesmas representam.

A tensão vivida pelo sujeito cindido numa cultura cindida passa a ser tema e atravessa as obras tanto de Plauto quanto de José Saramago. Nos dois autores, o topos da duplicidade e a questão identitária ganham dimensões literárias.

Entretanto, percebemos que cada uma das duas narrativas que ora trabalhamos apresenta uma perspectiva identitária diferente, conforme as posições e o contexto sóciohistórico permitem aos escritores trabalhar.

Partindo dessa premissa, temos que, segundo Hall (2003), a identidade é um fenômeno social em constante progresso e desenvolvimento. Ela é formada por meio da interação social e depende da competência interativa do sujeito para se constituir. Para além dessa função social, a identidade também resulta de uma relação dialética entre interioridade e exterioridade do indivíduo. O sujeito é, ao mesmo tempo, um ser teleológico e social.

Ainda de acordo com Hall, há três concepções de sujeito: o sujeito do iluminismo, o sujeito sociológico e o sujeito pós-moderno. O primeiro é baseado unicamente na pessoa humana, sendo o sujeito um indivíduo "totalmente centrado, unificado, dotado das capacidades de razão, de consciência e de ação" (Idem, 2003, p. 10). Seu centro reside em um núcleo interior, permanecendo o mesmo durante toda a existência.

Já o segundo sujeito - o sujeito sociológico - reflete a crescente complexidade do mundo moderno. Já não possui um núcleo interior centrado como o sujeito iluminista, mas uma consciência não é auto-suficiente. Já possui a percepção de que sua identidade é formada na relação com "outras pessoas importantes para ele", que lhe mediam valores, sentidos e símbolos - a cultura - dos mundos que habita (Idem, 2003, p. 11). Conforme 
esta concepção, o sujeito não é autônomo e constrói-se a partir da interação de sua essência interior com a sociedade (eu somado à sociedade). Sua interioridade é formada e modificada em um diálogo contínuo com os mundos culturais de sua exterioridade e com as identidades que esses mundos disponibilizam.

O terceiro e último sujeito - o sujeito pós-moderno - é classificado como não tendo uma identidade fixa, pois forma-se e transforma-se continuamente pelas características sociais que o rodeiam. Esse sujeito assume identidades diferentes em diferentes momentos, identidades que não são unificadas ao redor de um 'eu' coerente. "Dentro de nós há identidades contraditórias, empurrando em diferentes direções, de tal modo que nossas identificações estão sendo continuamente deslocadas" (Idem, 2003, p. 13).

\subsection{Identidades Clássicas, Solidez e Harmonia}

À primeira vista, podemos afirmar que a peça do escritor latino desvela ser o Anfitrião uma personagem que se apresenta com as qualidades do sujeito iluminista proposto por Hall. A identidade do sujeito romano da época de Plauto se define, basicamente, por um conjunto de representações particulares que se somam àquelas que definem o sujeito iluminista. O centramento do indivíduo é alicerçado na crença religiosa, pautada pela fé. O centro do sujeito plautino em Amphytruo é um individuo direcionado por uma concepção teísta e interior, que, mesmo frente à crise e à fragmentação, tem seu processo identitário centralizado por meio de um monolitismo implantado pela religião.

Tal indivíduo todo centrado, com o legado da religião imbuído em suas ações, é perfeitamente delineado no teatro de Plauto. Anfitrião, Alcmena e Sósia são seres totalmente manipulados pela divindade, descobrem que são enganados, mas a recompensa celeste não lhes permite permanecer na identitário-fragmentária pela qual passam. A fidelidade à religião permanece inalterada, mesmo quando as personagens chegam a não saber quem são quando suas identidades lhes são subtraídas.

Um exemplo dessa perda identitária com marcas de fidelidade religiosa se encontra no diálogo entre Sósia e Mercúrio a seguir:

MERCÚRIO: E agora? Estás convencido de que não és Sósia? SÓSIA: E tu afirmas que eu não sou eu? MERCÚRIO: E como não hei-de afirmá-lo, se Sósia sou eu?! SÓSIA: Juro, por Júpiter, que sou Sósia e que falo verdade. MERCÚRIO: E eu juro... por Mercúrio que Júpiter não acredita em ti: pois tenho a certeza de que ele se fiará mais em mim, sem juras, do que em ti, com os teus juramentos. 
SÓSIA: Então quem sou eu, se não sou Sósia? Não me dirás?! (PLAUTE, 2001,p. )

Plauto apresenta como núcleo da tensão dramática a crise de identidade pela qual passam as personagens Sósia e Anfitrião, ação que suscita reflexões sobre a questão da cisão do eu. As personagens vivem, a revelia da situação, fragmentações de suas identidades e que as colocam numa posição complexa. Essa crise só poderá ter fim por meio de sua aceitação - no caso do texto plautino, essa aceitação é religiosa. Ou seja, é a aceitação que unifica e torna os sujeitos da peça seres monolíticos. Tanto Anfitrião quanto Sósia vivem uma situação trágica que os coloca em crise.

Assim, ao compor uma peça em que as personagens tanto heróicas quanto divinas são carnavalizadas, Plauto está pondo em xeque a religião romana, mesmo que depois isso se negue dentro da peça. Segundo Hobsbawm e Ranger (Apud HALL), um dos elementos que marcam a identidade nacional é

(...) o que chamam de Invenção da Tradição, ou seja, "tradições que parecem ou alegam ser antigas são muitas vezes inventadas... Tradição inventada significa um conjunto de práticas (...), de natureza ritual ou simbólica, que buscam inculcar certos valores e normas de comportamentos através da repetição, a qual, automaticamente, implica continuidade com um passado histórico adequado (2003, p. 54, grifos do autor).

Assim Plauto está, de certa forma, reinventando a tradição. O escritor retoma a narrativa mitológica, recria as personagens e, ao acrescer, suprimir, inverter e deslocar elementos propõe uma nova forma de avaliar os valores, comportamentos e normas sociais que a sociedade da época possuía. Antes de negar essa postura, na verdade a peça plautina reavalia e dá continuidade a seu passado histórico, propondo novas identidades individuais, que influirão na identidade nacional.

As linhas do texto plautino demonstram que, na conversa entre Sósia e Mercúrio, está manifesto o empenho de cada um deles em afirmar sua identidade e, consequentemente, em desmascarar o impostor. Ambos buscam, dramaticamente, sua individualidade e tentam, a todo custo, negar sua tragicidade. Entretanto, apesar da troca de identidades feita por Júpiter deixar Sósia apavorado e Anfitrião indignado, manifestando a tragicidade da peça, o desenvolvimento do enredo plautino se dá vias cômicas, a plateia se diverte em vista do sofrimento da personagem.

Portanto, o sujeito plautino é centrado e que quando se desestabiliza tragicamente, logo volta a se estabilizar em favor desse centramento - tanto a época quanto a sujeição religiosa impedem que o descentramento seja mantido. Tudo é resolvido ao final da trama 
pela interferência de Júpiter ex machina. Quando o deus invade o espaço de Anfitrião, este contesta o senhor do Olimpo por estar em crise, descentrado. Mas quando Júpiter intervém com suas palavras e ação, logo tudo volta ao normal, pois a justificativa do senhor supremo reorganiza a vida de Anfitrião e reorganiza e desfaz a tragicidade da peça em favor da comicidade e do monolitismo da mesma.

O sujeito expresso pela dramaturgia plautina jamais contestará o deus. Anfitrião é monolítico. Apesar de sua revolta implícita, Plauto sempre reconduzirá seus escritos à unidade monolítica inicial. Dessa forma, a desordem instalada no inicio da peça é recuperada em seu término. O duplo cederá lugar ao uno: após o caos sempre haverá a ordem.

É a subversão paródica dessa condição que Saramago promoverá em seu romance ao recuperar, palimpsesticamente, a peça plautina e o mito da duplicação.

\subsection{Identidades Contemporâneas, e Duplicadas}

Ao retomar o topos do duplo, Saramago catalisará em seu romance elementos que permitirão erigir uma reflexão sobre a questão identitária do sujeito. Entretanto, diferentemente da perspectiva adotada por Plauto, a identidade expressa pelo sujeito saramaguiano é contemporânea.

No romance em questão, logo no início da trama, percebemos que a personagem principal atinge certo grau de tensão emocional, de ansiedade ou de medo, o que acaba por desestabilizar sua identidade, colocando-a em estado de alerta. A partir desse momento de transformação identitária, iniciam-se momentos de conflito interno ou de sentimentos extremos, o que desestabiliza ainda mais a personagem, permitindo com que sua identidade entre em choque, permitindo-nos refletir sobre esse processo.

Como já dissemos anteriormente há, para Hall (2003), três concepções identitárias de sujeito: a iluminista, a sociológica e a pós-moderna. Se o sujeito da primeira concepção é um indivíduo "totalmente centrado, unificado, dotado das capacidades de razão, de consciência e de ação" (Idem, p. 10), ele não pode ser expresso pelo romance de Saramago, já que todas as personagens estão em constante mudança e sem um núcleo interior que as direcione. Não há núcleo interior imutável, mas indecisão e mutabilidades periódicas. Exemplo dessa mutabilidade se dá nos trechos especulares do início e final da narrativa, no 
qual a personagem Tertuliano Máximo Afonso demonstra, em uma mesma situação, essa indecisão e mutabilidade periódica:

O auscultador foi deixado sobre a mesa, logo outra vez levantado, a voz de ambos irá repetir-se como um espelho se repete diante de outro espelho, Sou António Claro, que deseja, Chamo-me Tertuliano Máximo Afonso e sou professor de História no ensino secundário, Disse à minha mulher que se chamava Máximo Afonso, Foi para abreviar, o nome completo é este, Muito bem, que deseja, Já notou certamente que as nossas vozes são iguais [...] Não é só nas vozes que somos parecidos, Que quer dizer, Qualquer pessoa que nos visse juntos seria capaz de jurar pela sua própria vida que somos gêmeos, Gémeos, Mais que gémeos, iguais, Iguais, como, Iguais, [...]. (SARAMAGO, 2002, p. 177-178).

O telefone tocou. Sem pensar que poderia ser algum dos seus novos pais ou irmãos, Tertuliano Máximo Afonso levantou o auscultador e disse, Estou. Do outro lado uma voz igual à sua exclamou, Até que enfim. Tertuliano Máximo Afonso estremeceu, nesta mesma cadeira deveria ter estado sentado António Claro na noite em que lhe telefonou. Agora a conversação vai repetir-se, o tempo arrependeu-se e voltou para trás. É o senhor Daniel Santa-Clara, perguntou a voz, Sim, sou eu, Andava há semanas à sua procura, mas finalmente encontrei-o, Que deseja, Gostaria de me encontrar pessoalmente consigo, Para quê, Deve ter reparado que as nossas vozes são iguais, Parece-me notar uma certa semelhança, Semelhança, não, igualdade, Como queira, Não é só nas vozes que somos parecidos, Não entendo, Qualquer pessoa que nos visse juntos seria capaz de jurar que somos gêmeos, Gêmeos, Mais que gêmeos, iguais, Iguais, como, Iguais, simplesmente iguais [...]. (2002, p. 315).

Se na primeira citação a personagem principal toma a frente e conduz o diálogo, dono da situação, na segunda citação - a qual apresenta quase que a mesma situação Tertuliano Máximo Afonso se apresenta tímido, com medo e assustado.

A personagem saramaguiana tramita do que se conhece como sujeito moderno para o que Hall (e também Linda Huchteon) chamam de sujeito pós-moderno ou sujeito contemporâneo $^{59}$, que é fragmentado, descentrado.

A esse sujeito contemporâneo, sem apego a uma identificação fixa, Berman chamará de desnudo, ilustrando essa condição moderna e retratando a própria instabilidade e as mudanças constantes do mundo tecnológico:

A natureza do novo homem moderno, desnudo, talvez se mostre tão vaga e misteriosa quanto à do velho homem, o homem vestido, talvez ainda mais vaga, pois não haverá mais ilusões quanto a uma verdadeira identidade sob as máscaras. Assim, juntamente com a comunidade e a sociedade, a própria individualidade pode estar desmanchando no ar moderno. (BERMAN, 2007, p.136).

É justamente esse sujeito desnudo, contemporâneo, fragmentado que o romance de José Saramago expressa. Uma personagem que migra, constantemente, de sua condição de

\footnotetext{
59 Há também a variante sujeito da modernidade tardia, proposta por Fredric Jameson em seu Pós-
} modernismo: a lógica cultural do capitalismo tardio. 
sujeito sociológico para pós-moderno - para ficarmos na terminologia de Hall. Tanto Tertuliano Máximo Afonso quanto António Claro/Daniel Santa-Clara são seres fronteiriços, que se situam entre o eu e o outro.

Transformado continuamente pelas características sociais que o rodeiam e sem um centro unificador, o sujeito "pós-moderno"60 é um indivíduo que apresenta várias identidades, eventualmente contraditórias, por modo de usá-las conforme as necessidades de mudança estruturais e/ou institucionais. A identidade desse sujeito é definida pela História, e não mais pela religião. Assim se expressam os indivíduos de $O$ Homem Duplicado. Esse sujeito, que assume identidades diferentes em diferentes momentos e que apresenta mutabilidades conforme suas realidades e necessidade.

Temos, como exemplo dessa mutabilidade, a postura do professor de História ao assumir o lugar de seu duplo:

(...) levo-a, ninguém me verá, E como me vais levar tu, se já não tens carro, Estou com o que era dele. A mãe abanou a cabeça tristemente e disse, O carro dele, a mulher dele, só falta que passes a ter também a sua vida, Terei de descobrir outra melhor para mim, e agora, por favor, vamos comer qualquer coisa, tréguas à desgraça (HD, p. 306).

Um eu devastado e tentando se reconfigurar por medo de ser deflagrado. Assim se encontra a personagem principal do romance. Um sujeito sem direção do que fará de sua vida:

(...) agora não sabe o que fazer com o erro em que ele próprio, de um instante para outro, se tinha visto convertido. (p. 28)

E depois, perguntou o professor de História, como uma criança que não sabe que não adianta perguntar pelo que ainda não sucedeu, que farei depois disto, que farei depois de saber que esse homem entrou em quinze ou vinte filmes, que, tanto quanto pude verificar até agora, além de recepcionista, foi caixa de banco e auxiliar de enfermagem, que farei. (SARAMAGO, 2002, p. 75).

Essa quebra de referências no romance reconfigura, sistematicamente, as diversas formas de o narrador buscar sua identidade perdida. E essa obsessão pelo duplo é o que opõe, por exemplo, a tradição metafísica que se funda no um, na unidade, na identidade, a um pensamento do múltiplo, que se funda na diferença, no corpo, no rastro imotivado, no rizoma. Representar é apresentar de novo e, assim como repetir, pressupõe algo que lhe é anterior, que garanta sua possibilidade. Para a metafísica, a semelhança pressupõe uma identidade que se reconhece a si enquanto presença, uma unidade, uma origem, um

\footnotetext{
${ }^{60}$ Usamos o conceito de sujeito pós-moderno de ora em diante segundo a perspectiva proposta por Hall.
} 
princípio que funda toda a cadeia que se dirige a um telos e ordena o mundo em pares de opostos.

O sujeito já não está sozinho: o tu responde aos sentimentos do eu. Dessa forma, ao negar o outro, as personagens não conseguem se relacionar uma com a outra, o "eu" fíca isolado do "outro", unidade é cindida, cujo desmembramento torna o sujeito mais fraco. O outro é o fisionomicamente igual, mas portador de um universo interior, histórico e social diferentes. Sendo assim, o outro é portador de identidade, mas também de alteridade.

A identidade surgiu como questão antropológica e sociológica na década de 70 do século passado. Ao tomarmos esse fato como marco, a Europa deixa de ser local de saída e se tornou lugar de entrada do "outro". Ou seja, já não se exporta o sujeito europeu como modelo de perfeição, mas ele passa a incorporar diversas e diferentes categorias, agora matéria da diversificação a que foi submetido ou a que se submeteu.

É dentro dessa perspectiva de lugar de entrada do "outro" que surge o sujeito pósmoderno. Acompanhando mais de perto a reflexão realizada por Hall, notamos que esse sujeito está confrontado "por uma multiplicidade desconcertante e cambiante de identidades possíveis, cada uma das quais poderíamos nos identificar - ao menos temporariamente" (2003, p. 13). Grande parte dessa mudança formadora do sujeito pósmoderno se dá por conta de um fenômeno impactante chamado globalização, na qual as sociedades modernas são vistas "como sociedades de mudança constante, rápida e permanente" (Idem, 2003, p. 14). Ou seja, essa sociedade possui uma forma altamente reflexiva de vida, na qual a cada interconexão global ondas de transformação social atingem a superfície toda da terra, mesmo que superficialmente. E esse "desalojamento do sistema social" que se dá pelo processo de globalização provoca transformações tanto no tempo quanto no espaço.

Mas, o que mais caracteriza a sociedade contemporânea é o fenômeno da descontinuidade. Segundo Harvey (Apud HALL, p. 16), essa descontinuidade é um rompimento com a condição precedente caracterizada por um sem fim processual de rupturas e fragmentações internas. Laclau (Idem, Ibidem) considera esse processo como deslocamento, uma estrutura cujo centro é deslocado e substituído por uma pluralidade de centros. Ora, essa sociedade que é atravessada por essa diversidade de antagonismos e divisões, mas que não se desintegra por sua conjuntura estrutural, só pode articular sujeitos cujas identidades sejam abertas, em constante mudança e afeiçoamento, ou, para usar a terminologia de Hall, descentrada. 
Um exemplo destes descentramentos está no trecho em que Tertuliano Máximo Afonso assiste ao filme de António Claro/Daniel Santa-Clara:

Outra vez sentado na cadeira, ocupando portanto a posição relativa da actriz que interpretava o papel de Inês de Castro, brincou a ser, também ele, cliente do hotel, Chamo-me Tertuliano Máximo Afonso, anunciou, e depois, sorrindo, E você, a pergunta era das mais conseqüentes, se duas pessoas iguais se encontram, o natural é quererem saber tudo uma da outra, e o nome é sempre a primeira coisa por que imaginamos que essa é a porta por onde se entra (HD, 2002, p. 24).

Ao assistir o filme interpretado por seu duplo, o professor de História perde seu centro, se fragmenta, e experimenta ser seu duplo; se coloca no lugar do outro, perde seu centro, mas transita entre duas realidades: se imagina ator, mas assume seu próprio nome. A personagem vive o que Hall chama de descentramento. Está em um processo de descontinuidade, rompendo com a condição precedente e se fragmentando internamente. Em outras palavras, Tertuliano Máximo Afonso vive uma situação de limiar.

Assim também acontece no momento em que a personagem principal vai escolher o que irá comer antes de assistir ao filme:

Depois de ter passado pela casa de banho foi ao quarto para mudar de roupa,
trocou de sapatos e calças, enfiou um pulôver por cima da camisa, deixando ficar
a gravata porque não gostava de ver-se esgargalado, e entrou na cozinha. Tirou
de um armário três latas de diferentes comidas, e como não soube por qual
decidir-se, lançou mão, para tirar à sorte, de uma incompreensível e quase
esquecida cantilena de infância que muitas vezes, naqueles tempos, o tinha
deixado fora de jogo, e rezava assim, um dó li tá, era de mendá, um sulete
colorete, um dó li tá. Saiu um guisado de carne, que não era o que mais lhe
apetecia, mas achou que não devia contrariar o destino. Comeu na cozinha,
empurrando com um copo de vinho tinto, e, quando terminou, quase sem pensar,
repetiu a cantinela com três migalhas de pão, a da esquerda, que era o livro, a do
meio, que era os exercícios, a da direita, que era o filme. Ganhou Quem Porfia
Mata Caça (...) (HD, 2002, p.16).

A indecisão por escolher tanto o que comerá quanto aquilo que fará depois de comer é típico do sujeito do limiar, que não sabe qual sua postura frente às coisas. Ele está contrabalançado pelos contrários. Não é mais isso ou aquilo, mas isso e aquilo. Assim, a brincadeira auxilia a personagem em suas tomadas de decisões e - na falta de alguém para interagir - é perspectivada no lugar do outro. A personagem novamente se descentra, fragmenta-se.

Está em um processo de descontinuidade, rompendo com a condição precedente e se fragmentando internamente. Em outras palavras, Tertuliano Máximo Afonso vive uma situação de limiar, sempre transitando em um processo de formação de identidade.

Podemos, pois, reconhecer que a questão da identidade em O Home Duplicado visa, também, a um redimensionamento do eu em um mundo condicionado pelo 
capitalismo e pela cultura consumista, um ente perdido que tem seus modelos de comportamento sociais ditados por essa sociedade. Dentro dessa perspectiva,

uma vez que a identidade muda de acordo com a forma como o sujeito é interpelado ou representado, a identificação não é automática, mas pode ser ganhada ou perdida. Ela tornou-se politizada. Esse processo é, às vezes, descrito como constituindo uma mudança de uma política de identidade (de classe) para uma política de diferença. (HALL, 2003, p. 21)

O sujeito expresso em $O$ Homem Duplicado passa por um descentramento regido por concepções mutantes do humano, ou seja, o sujeito é visto como uma figura discursiva que é moldada pelos discursos do pensamento da sociedade e pelos seus processos de moldura. Esse sujeito, líquido por excelência, é "a figura do individuo isolado, exilado ou alienado, colocado contra o pano-de-fundo da multidão ou da metrópole anônima e impessoal" (Idem, p. 32). Assim o descreve o narrador:

Para se ter uma ideia clara do seu caso [de Tertuliano Máximo Afonso], basta dizer que esteve casado e não se lembra do que o levou ao matrimónio, divorciou-se e agora não quer nem lembrar-se dos motivos por que se separou. (p. 9)

O Double António Claro/Daniel Santa-Clara, expressará, de acordo com Hall,uma identidade fluida. A personagem se vê deslocada em sua identidade e na sua identificação com o espaço e o tempo. Diante de um mundo em constante transformação, António Claro/Daniel Santa-Clara acaba por perceber o mundo de forma contraditória, sem sentido único, o que o descentraliza. Podemos notar isso por intermédio da solidão que acompanha a personagem. Mesmo casada, ela sente-se constantemente sozinha:

Podíamos ir para a casa de campo, peço a alguém da povoação que vá limpar-nos o jardim, Sufoco naquela solidão, Então vamos para outro sítio, Já te disse que prefiro ficar em casa, Será outra solidão, Mas nesta sinto-me bem, Se é isso o que realmente queres, Sim, é isso o que quero realmente. Não havia mais que dizer. O pequeno-almoço foi tomado em silêncio, e meia hora mais tarde Helena estava na rua, a caminho do emprego. António Claro não tinha a mesma pressa, mas também não tardou a sair (HD, 2002, p. 234).

Essa profunda acídia que toma conta das duas personagens tente ser resolvida pelas mesmas quando um conhecer a existência do outro. Entretanto, por não haver solução no romance a mesma sempre retorna. Enquanto dialogam apenas consigo mesmos (projetando o outro na figura do Senso Comum no caso de Tertuliano Máximo Afonso ou assumindo outras curtas identidades em filmes no caso de António Claro/Daniel Santa-Clara), as personagens se alienam, vivem no limiar de suas vidas e não possuem uma autoconsciência de si mesmas. Elas flanam nos interstícios de suas inquietações, mas não buscam respostas com o outro, esquecem que dependem do outro para (sobre)viver. 
A verdade, ou as verdades, que as personagens de $O$ Homem Duplicado acabam por buscar em suas trajetórias é aquela relacionada com a constituição mais básica da identidade: “quem somos nós?”. Entretanto, essa resposta só será, em parte, atingida se as personagens aceitarem a identidade como um processo dinâmico de identificação do indivíduo com o outro e com os papéis sociais por ele representados ao longo da vida. Mas temos dois seres perdidos dentro de seus "eus", que não conseguem se aproximar e aceitar um ao outro. É necessário que as duas personagens se interajam para que exista o eu, já que "o homem tem uma necessidade estética absoluta do outro, (...) que é capaz de criar para ele uma personalidade externamente acabada; tal personalidade não existe se o outro não a cria" (BAKHTIN, 2006, p. 33).

Tertuliano Máximo Afonso é o primeiro a sentir essa necessidade do outro, pois, ao reconhecer seu duplo nos filmes de série B, inicia sua busca por seu duplo em um processo que lhe transtorna. Já António Claro/Daniel Santa-Clara só notará essa necessidade do outro quando encontrar o professor de História. Por fim, as duas personagens viverão em trânsito, no limiar de suas identidades. Para elas não há mais isto ou aquilo, mas isto e aquilo. Tanto que, a certo momento elas deixam de ser a elas mesmas para encarnarem a figura de seu duplo.

Mikhail Bakhtin, ao referir-se à carnavalização, destaca a questão do limiar nas narrativas polifônicas. No romance polifônico temos "consciências eqüipolentes e seus mundos que aqui se combinam numa unidade de acontecimento, mantendo a sua imiscibilidade.” (BAKHTIN, 1998, p. 4, grifos do autor). Nesse jogo em que as múltiplas vontades não se sobrepõem, as personagens que serão expressas pelo romance não podem possuir uma identidade acabada, eles tem de ter personalidades possíveis, que se moldam à realidade circundante ou a desafiam em favor de uma outra realidade ou possibilidade. É pela divergência entre personagens e pelo confronto entre personagens e autor que se formam as diversas opiniões que o romance polifônico apresenta em seu interior. Não há consenso. Por isso, a personagem do romance se apresenta por meio de mudanças bruscas e repentinas de ser e de agir:

O telefone tocou. (...) Tertuliano Máximo Afonso levantou o auscultador e disse, Estou. Do outro lado uma voz igual à sua exclamou, Até que enfim. Tertuliano Máximo Afonso estremeceu, (...). Agora a conversação vai repetir-se (...). É o senhor Daniel Santa-Clara, perguntou a voz, Sim, sou eu, Andava há semanas à sua procura, mas finalmente encontrei-o, Que deseja, Gostaria de me encontrar pessoalmente consigo, Para quê, Deve ter reparado que as nossas vozes são iguais, Parece-me notar uma certa semelhança, Semelhança, não, igualdade, Como queira, Não é só nas vozes que somos parecidos, (...) Acabemos com esta conversa, tenho que fazer, Quer dizer que não acredita em mim, Não acredito em 
impossíveis, (...) Tertuliano Máximo Afonso respirou fundo, depois perguntou, Onde está, Numa cabina telefónica não muito longe da sua casa, E onde posso encontrá-lo, Terá de ser num sítio isolado, sem testemunhas, (...) Muito bem, repetiu Tertuliano Máximo Afonso pousando o telefone. Puxou uma folha de papel e escreveu sem assinar, Voltarei. Depois foi ao quarto, abriu a gaveta onde estava a pistola. Introduziu o carregador na coronha e transferiu um cartucho para a câmara. (...). Entalou a pistola no cinto e saiu (HD, 2002, p. 315-16).

Retomo o fragmento para pensar a mudança de agir. Se antes a personagem ameaça ir armado, mas não leva armas, agora, já no final da trama, ela não diz nada, entretanto, armasse e vai ao encontro do outro já imaginando um encontro trágico.

A atitude divergente com a postura anterior da personagem foi formada, justamente, pelo confronto que já havia acontecido anteriormente. É ele quem muda a perspectiva de Tertuliano Máximo Afonso. Como define Bakhtin, "a verdade não nasce nem se encontra na cabeça de um único homem; ela nasce entre os homens, que juntos a procuram no processo de sua comunicação dialógica" (Idem, p.110, grifos do autor).

Se esse sujeito inacabado não apresenta identidade fixa e nem definida, sua manifestação só pode ocorrer em um espaço em que a relatividade e a polêmica sejam tônicas. Esse espaço é o que Bakhtin chama de limiar. O limiar expressa, então, um espaço que corresponde ao inacabamento, lugar de trânsito, de conflito e de tensão, carnavalesco por excelência. Opõe-se ao limite, espaço que corresponde ao fechamento, ao acabamento, à perfeição. O limiar é a porta da ficção, uma "superfície que separa a região do mesmo e a região do outro" (BACHELARD, 1993, p. 224). Nele, as fronteiras embaralham-se bruscamente ou desaparecem. No romance de Saramago o limiar é o espaço por excelência nos quais as personagens transitam. Um exemplo desse trânsito se encontra logo no início da narrativa, quando Tertuliano Máximo Afonso sente uma presença estranha em sua casa, sai a procurá-la e para diante do vídeo. Ao assistir ao filme Quem porfia mata caça, o professor de História nota a imagem do ator televisivo que se semelha à sua, observa o ator como se fosse ele e afirma ao ver o outro na tela: "sou eu" (HD, 2002, p.23).

É a passagem pelos limiares que leva as personagens a ter mais informações acerca do outro e de si mesmo, afinal, é só a o partir do outro que as personagens conseguem entender tudo o que deseja saber, uma vez que o que dá o verdadeiro sentido do eu é a busca pelo outro. Outro espaço do limiar é a escola, local em que o desenrolar da trama inicia-se (é nela que Tertuliano Máximo Afonso recebe o conselho do professor de Matemática em assistir ao filme Quem Porfia Mata caça). É mele que o professor de História transita e passa por uma crise de identidade que a conduz a diferentes caminhos. Assim: 
(...) De uma pessoa que declarou ter estado durante dois dias entregue à serenidade de uma leitura histórica, observou o colega de Matemática, esperaria eu tudo, menos essa cara atormentada, É impressão sua, não tenho nada que me atormente, devo é ter cara de quem dormiu pouco, Você poderá dar-me as razões que quiser, mas a verdade é que desde que viu aquele filme não parece o mesmo, Que quer dizer com isso de que não pareço o mesmo, perguntou Tertuliano Máximo Afonso num tom inesperado de alarme, Nada senão o que disse, que o noto mudado, Sou a mesma pessoa, Não duvido, É verdade que ando algo apreensivo por causa de uns assuntos de ordem sentimental que ultimamente se me complicaram, são coisas que podem suceder a qualquer, mas isso não significa que me tenha tomado em outra pessoa, Nem eu o disse, não tenho nenhuma dúvida de que continua a chamar-se Tertuliano Máximo Afonso e é professor de História nesta escola, Então não percebo por que é que insiste em dizer que não pareço o mesmo, Desde que viu o filme (...). (Idem, p. 144-45).

Ao transitar pela escola e interagir com seus companheiros de trabalho principalmente o professor de Matemática - Tertuliano Máximo Afonso percebe seu inacabamento e reflete sobre sua própria postura, culminando em uma identidade fragmentada e em constante (trans)formação.

A identidade do protagonista, representada pela dualidade entre a ficção (seu duplo existente na fita de vídeo) e a realidade cotidiana, começa a se multifacetar como a identidade do indivíduo liquido contemporâneo. A personagem está, no trecho citado, no limiar de confluência, ou seja, ela se descobre fundamentalmente ambivalente. É assim também que Bauman, por outras palavras, define o sujeito fluido:

O que foi separado não pode ser colado novamente. Abandonai toda a esperança de totalidade, tanto futura quanto passada, vós que entrais no mundo da modernidade fluida. Chegou o tempo de anunciar, como o fez recentemente Alain Touraine, o "fim da definição do ser humano como um ser social, definido por seu lugar na sociedade, que determina seu comportamento e ações". (2005, p. 29).

A identificação pela qual passa ao assistir o filme provoca uma mudança na personalidade de Tertuliano Máximo Afonso enquanto professor. A personagem realmente passa de uma personalidade mais "sociológica" para uma personalidade mais próxima da “pós-moderna". Há uma dissolução do sujeito por conta de sua obnubilação ao ver seu duplo no vídeo. Temos então o primeiro descentramento da personagem. Ele abandona sua postura rígida quanto ao horário das aulas, seus compromissos com a correção dos exercícios, o preparo das aulas e das provas e até sua leitura sobre os Caudeus para dedicar-se inteiramente a descobrir quem é esse que se parece tanto consigo.

A partir desse momento, a personagem passa seu tempo quase que todo a assistir vídeos nos quais aparecem o seu duplicado. Parece que há uma espécie de contaminação dos elementos ficcionais - filmes - pelos mais factuais - livro histórico sobre os Caudeus, dentre outros. É a partir desse fato que a personagem passa a trocar sua vida de professor - 
que estuda e pesquisa - por uma vida de procuras, já que não sossegará enquanto não descobrir quem seja seu duplo. Nesse processo ele troca o livro de História pelos filmes ou seja, o factual pelo ficcional - e a vida regrada e com horários do sujeito sociológico pela vida "desordenada" do sujeito pós-moderno. Há, implícita nessa troca, uma ao epíteto do livro já que foram os Caudeus que criaram o primeiro código de conduta da nossa História - o Código de Hamurabi. Ao trocar o livro sobre os Caudeus pelos filmes de ficção, a personagem opta abandonar a ordem em favor do Caos - opção, aliás, que acompanhará Tertuliano Máximo Afonso ao longo da narrativa. Temos, via de regra, a sobreposição da duplicidade presente nos filmes sobre a ordem prescrita no Código de Hamurabi, desestabilizando-o; processo que se repetirá, de forma diferente, durante todo o romance, pois o duplo da personagem surgirá para desestabilizar a ordem de sua vida cotidiana: "Perceber-se duplo de alguém é perturbador (...)." (HD, 2002, p. 28), dirá a personagem principal da narrativa.

A temática do duplo, no romance de José Saramago, além de proporcionar ao leitor o estranhamento, a dúvida, a angústia do não saber que caminho está percorrendo, metaforicamente, nega a ordem e a lei, instaurando uma situação de limiar, na qual o sujeito se situa como fronteiriço, entre o eu e o outro. Esta oposição entre o "real" e o ficcional proposto nas entrelinhas do romance de Saramago é um dentre os vários fatos que prova ser esta narrativa uma alegoria sobre a questão da História e da ficção como já comentamos anteriormente.

A presença desse outro, física e emocionalmente, concretiza a existência do eu. Conhecendo a alteridade, o eu descobre-se a si próprio como ser humano e exibe o seu ser profundo. $\mathrm{O}$ eu, mesmo querendo, não existe sem o outro. A identidade do indivíduo também é composta pelo outro, pois é pela imagem do outro que construímos a de nós mesmos; e é pela conjugação desta às imagens que são formadas sobre nós a partir da visão das outras pessoas que surge a integralidade do "eu". A construção da identidade individual é inextricavelmente relacionada à construção da identidade do grupo; dessa forma, o tecido social é que gera os sentimentos individuais das personagens e que desencadeia sua crise. O duplo, nesse caso, firma-se como o elemento de metamorfose na identidade das personagens, as quais viverão acontecimentos excepcionais capazes de dar início ao processo de autoconsciência.

A identidade individual é, portanto, parte da identidade coletiva, pois está circunscrita em uma relação de reciprocidade com o grupo ao qual pertence. Ao 
observarmos o indivíduo, há que se levar em conta os grupos e subgrupos no quais ele está inserido como ser humano. Ao negar-se inserir numa comunidade identitária (afinal, essa inserção compete uma troca de conceitos subjetivos aos quais a personagem se nega a realizar), Tertuliano Máximo Afonso se exclui do possível autoconhecimento, que gera o conflito na construção da identidade e uma consequente insatisfação do ser.

Depois de assistir ao filme, Tertuliano Máximo Afonso passa por seu processo de fragmentação, perdendo suas bases por negar-se a aceitar o outro enquanto seu duplo. $\mathrm{O}$ duplo passa, antes de mais nada, pelo tema identidade, ou, em outras palavras, pelo modo como o sujeito se concebe ora único ora projetado especularmente em outro de si mesmo. Essa fragmentação pela qual passa a personagem principal é definida por Hall (2005, p. 13) como sendo a do sujeito pós-moderno, já que a fragmentariedade não é necessariamente o acabar da mesma, mas uma de suas possibilidades de existência.

Ao assistir ao vídeo, Tertuliano se descobre outro; tal processo de clivagem também é representado pela forma da narrativa:

Sim, era aquilo, o aparelho de televisão, o leitor de vídeo, a comédia que se chama Quem Porfia Mata Caça, uma imagem lá dentro que havia regressado ao seu sítio depois de ir acordar Tertuliano Máximo Afonso à cama. (HD, 2002, p. 22).

No trecho citado, Tertuliano Máximo Afonso desloca-se até aparelho de televisão e de vídeo que estão ligados. Todo o trecho (e, por conseguinte, quase que toda a cena) é construído por diversas pausas, ora representadas por pontos finais, ora por vírgulas. Essa forma de construção assemelha-se, feitas as devidas proporções, como imagens cinematográficas.

A imagem cinematográfica até bem pouco tempo era construída, via de regra, por meio de diversas "fotografias" que vão se substituindo para criar a impressão de movimento. Essas partículas de imagens estáteis, mas progressivas produzem o movimento da imagem. É essa qualidade de partículas progressivas que possibilita a proximidade com as curtas frases, aproximando a arte escrita do texto saramaguiano da representação fílmica. Identicamente ao processo fílmico, as frases usadas pelo escritor na narrativa em análise são constantemente sucedidas vírgula após vírgula imitando, assim, as sobreposições cinematográficas em que uma imagem surge uma após a outra numa sequência instantânea e rápida. As frases são, figurativamente, a representação gráfica das partículas fotográficas presentes no filme, produzindo, dessa forma, a representação, no 
papel, da imagem visual. Temos, na representação sígnica do romance, um processo icônico no qual o texto se torna aquilo que representa.

Outro processo de aproximação acontece pela forma como a narrativa apresenta os acontecimentos da trama. Todos os elementos surgem como se fossem fotografias de um filme. São pequenos flashes que vão construindo a imagem da narrativa. São takes dos objetos que compõem o quadro narrativo que esta a ser descrito pelo narrador, tais como o aparelho de televisão, o leitor de vídeo e a fita de Quem Porfia Mata Caça. Essa retratação narrativa do momento em que Tertuliano Máximo Afonso assiste ao filme de seu duplicado ilustra como a identidade da personagem principal é entrecortada, dividida. O filme, que é construído em pedaços, ao se aproximar do modo de composição narrativa de Saramago, sugere a quebra, o montar e desmontar da identidade da personagem Tertuliano Máximo Afonso ao longo da trama.

A identidade da personagem se constitui nesse árduo processo de modelagem que, pela sua lenta formação/gestação, se assemelha a um parto. Ficção e metaficção confluem nesse processo de criação em que, por meio dessa formação/gestação, mimetiza simultaneamente o nascimento de um ser vivo e de uma obra de arte. Temos um exemplo dessa gestação no trecho a seguir que acontece em uma conversa entre Carolina e Tertuliano Máximo Afonso:

(...) Não ando a dormir, não sou sonâmbulo, tenho a minha vida, o meu trabalho,
Há uma parte de ti que dorme desde que nasceste, e o meu medo é que um dia
destes sejas obrigado a acordar violentamente, (...) Logo, tu és um daqueles
troianos que não acreditaram, e por isso Tróia foi queimada, Neste caso não há
nenhuma Tróia para queimar, Quantas Tróias com outros nomes e noutros
lugares foram queimadas depois dessa, Inúmeras, Não queiras tu então ser mais
uma, Não tenho nenhum cavalo de madeira à porta de casa, E se o tiveres, escuta
a voz desta Cassandra velha, não o deixes entrar, Estarei atento aos relinchos (...)
(Idem, p. 260)

A fala de Carolina confirma a necessidade de um equilíbrio entre a individualidade e a alteridade que está em processo de formação em seu fillho. É ao homem ser socializado, sendo o isolamento o pior castigo e a mais triste infelicidade que a sociedade lhe pode infligir. Lembremo-nos da amargura das cartas de Cícero quando de seu exílio de Roma, ou, hodiernamente, da solidão angustiada que se vive nas prisões. Tertuliano Máximo Afonso é alguém que representa dois papéis sociais conflitantes, o que, teoricamente, impede que ele avance em seu processo de auto-reconhecimento e permaneça em seu mimético de nascimento do ser humano/obra de arte. 
Essa identidade multifacetada da personagem se contrapõe à profissão que ela exerce. Tertuliano Máximo Afonso ministra suas aulas de História baseando-se no ensino de uma ciência que se quer exata e dona de todo conhecimento. O método científico positivista da História assume uma personalidade ligada ao racionalismo e ao cientificismo, postulados que alicerçam seu modo de trabalho.

Reforça-lhe a conveniência de não sair de casa o facto de ter trazido trabalho da escola, os últimos exercícios dos seus alunos, que deverá ler com atenção e corrigir sempre que atentem perigosamente contra as verdades ensinadas ou se permitam excessivas liberdades de interpretação. A História que Tertuliano Máximo Afonso tem a missão de ensinar é como um bonsai a que de vez em quando se aparam as raízes para que não cresça, uma miniatura infantil da gigantesca árvore dos lugares e do tempo, e de quanto neles vai sucedendo, (...) (HD, 2002, p. 15).

O pequeno excerto demonstra como se delineia a concepção de História para Tertuliano Máximo Afonso. A matéria que a personagem leciona é - para ele - totalmente verdadeira, sem excessos ou deslimites. Essa concepção só mudará a partir do momento em que sua identidade sofre o abalo por meio de seu duplo.

Quanto a António Claro/Daniel Santa-Clara, não sabemos como se dá esse esfacelamento da identidade em primeiro momento, pois o narrador não nos descreve a vida da personagem antes de ela se encontrar com o professor de História. Todavia, podemos inferir por conta de suas ações e diálogos que a questão da crise de identidade está atrelada, no ator, ao colapso do bem estar social que este sofreu quando da descoberta de seu duplo Tertuliano Máximo Afonso. Quando o ator descobre existir um duplo seu, cresce nele uma sensação de insegurança que o obriga, por exemplo, a ir armado ao seu encontro com o professor de História.

O resultado da condição de instabilidade e limiaridade provocado pelo reconhecimento entre o ator e o professor é que, depois do encontro entre eles o ator coadjuvante não consegue mais se manter estável em seu relacionamento com a sua esposa Helena. A confrontação física e a certeza de que tanto o ator quanto sua o professor de História são iguais em cada pequeno detalhe do corpo dá-lhes a sensação de um roubo da suas identidades, fazendo com que um se sinta constantemente ameaçado pela presença do outro.

Transfigurados pelo encontro, Tertuliano Máximo Afonso e António Claro/Daniel Santa-Clara tentam, a todo custo, esquecer seu duplo - o que lhes causou uma espécie de nova diluição fragmentaria da identidade como modo de negociar com as necessidades de mudança estruturais e institucionais. Contudo, essa mudança é irreversível. O outro muda 
completamente a figura, o pensamento, as ações e a alteridade do eu. Como referenda Bakhtin,

(...) não tomo consciência de mim mesmo senão através dos outros, é deles que eu recebo as palavras, as formas, a tonalidade que formam a primeira imagem de mim mesmo. Só me torno consciente de mim mesmo, revelando-me para o outro, através do outro e com a ajuda do outro. (Apud TODOROV, 1981, p. 148) ${ }^{61}$

Pode-se afirmar, então, que é somente na interação com as outras pessoas que o ser humano se constitui. Subjacente a essa perspectiva está a ideia de que o eu só existe por meio do outro e o outro é aquele que nos direciona, ou, nas palavras do teórico russo, “ocorre que nossa própria relação com a imagem externa não é de índole imediatamente estética, mas diz respeito apenas ao seu eventual efeito sobre os outros (...)" (BAKHTIN, 2006, p.30). O teórico russo apenas reafirma que só podemos definir nossa posição em relação ao outro, isto é, somos o que somos para e através do outro. Nossa alteridade é formada e mediada pelo outro.

Contudo, mesmo com medo de mudar, as personagens sabem que serão transformadas. Elas são projetadas a mudar desde o início do romance, e essa mudança é anteipada ao leitor por meio de diversos dados. Um desses dados antecipadores sao os nomes das personagens. Se, ao sermos nomeados adquirimos certa identidade, quando pensamos na atitude do autor em nomear as personagens de seus romances, não podemos pensar que essa nomeação aconteça de forma inocente. Ela reflete uma intenção significante do autor em também expressar, por meio dos nomes, a identidade de suas personagens. Tanto que no romance o conhecimento das personagens se dá ao leitor, quase que exclusivamente, por meio dos nomes como no trecho a seguir:

Poderei falar com o senhor Daniel Santa-Clara, perguntou Tertuliano Máximo
Afonso quando a mulher dele atendeu, Suponho que é a mesma pessoa que ligou
para aqui no outro dia, estou a reconhecê-lo pela voz, disse ela, Sim, sou eu, O
nome, por favor, Não creio que mereça a pena, o seu marido não me conhece,
Também o senhor não o conhece a ele, e apesar disso sabe como se chama, É
natural, ele é actor, portanto uma figura pública, Todos nós andamos por á, mais
ou menos somos todos figuras públicas, o número de espectadores a assistir é
que difere, O meu nome é Máximo Afonso, Um momento. (HD, p.177).

Sabendo que o nome é a forma de sermos reconhecidos no mundo, o professor de História utiliza-se, no exemplo citado, apenas de seu sobrenome, numa tentativa de preservar sua identidade verdadeira à esposa de António Claro/Daniel Santa-Clara. O prénome Tertuliano, que no início do romance fora escondido pelo professor para não revelar

\footnotetext{
${ }^{61}$ Todas as traduções dessa obra - cujo original é francês - são de nossa responsabilidade.
} 
sua completa identidade ao funcionário da loja de filmes - atitude que acaba por dar errado, já que o mesmo lê seu nome na ficha da loja e desmascara a identidade de Tertuliano Máximo Afonso por conta de sua reação ao ouvir seu nome -, agora é escondido para não revelar a identidade nem a Antonio Claro/Daniel Santa-Clara ou à esposa do ator, Helena.

De fato, todas as personagens revelam, por meio de seus nomes, uma faceta de sua identidade, além de hipertextualizarem de forma simples ou imitativa com algumas referências emblemáticas da cultura ocidental. Ancorados em Ziff, acreditamos que a definição do nome próprio é "um ponto fixo no mundo que se move" (1996, p. 102) ${ }^{62}$. O teórico americano vê nos ritos batismais de nomeação a maneira mais precisa de determinar uma identidade para o indivíduo.

Feita a ressalva, pensemos no nome Tertuliano Máximo Afonso. A personagem que catalisa a história possui um nome triplo. Essa tripartição nominalista pode nos direcionar para a duplicidade da personagem que virá a ser, no final do romance, um sujeito triplicado. Ao pensarmos no significado que cada nome aqui representa, poderemos comprovar a tripartição da personagem, calcados nos próprios sinais que o nome dela nos aponta.

Uma primeira observação diz respeito ao nome Tertuliano, que remete ao vocábulo tertius, palavra latina que pode significar tanto um nome quanto a palavra "terceiro" (SARAIVA, 2006, p. 1194), fato que sugere o porquê de a personagem possuir três nomes. O nome oferece uma espécie de chave interpretativa da vida da personagem, pois o vocábulo tertius aponta para a questão da triplicação pela qual a personagem passa no fim do romance, já que ela encontrará, no final da narrativa, um terceiro sujeito que se diz ser igual a ela. O nome tertius é o primeiro sinal que o vocábulo Tertuliano nos aponta, e já nele notamos o esfacelamento identitário que o romance reflete.

Tertuliano remete também, pela própria etimologia de seu nome, a "tertúlia" um substantivo coletivo que significa "reunião familiar; agrupamento; assembléia" (CUNHA, 1986, p. 766), fato que justifica esse conjunto de nomes em sua designação.

Por fim, o vocábulo Tertuliano também remete-nos à figura histórica, de origem latina, Quintus Septimus Florens Tertulianus. Pensemos em primeira instância no primeiro nome da personagem principal: Tertuliano. Como informa Paratore (1980, p. 862),

\footnotetext{
${ }^{62}$ Tradução de nossa responsabilidade.
} 
Tertulianus era filho de pai romano - centurião da guarda pró-consular - e de mãe talvez africana; viveu entre os anos de 160 e 225 d.C., nascendo em Cartago, por volta do ano 160 d. C. Foi clérigo, doutor em Ciências Jurídicas e apologista de renome na Igreja Católica no século II. É autor de numerosos discursos-escritos-apologéticos dirigidos aos governantes provinciais suplicando a liberdade religiosa para os cristãos e dividindo com Santo Agostinho o primado na literatura latina cristã.

Outro detalhe que chama a atenção é que o nome Tertuliano, de origem latina, ao nomear a personagem do romance saramaguiano, permite que façamos uma espécie de remissão paródica ao texto/contexto com o qual dialoga. Ao eleger Tertuliano como nome, a desinência /ano/ evoca nomes de imperadores romanos, tais como Diocleciano, Vespasiano, Domiciano, Aureliano, dentre outros; esses imperadores de figuração forte, brava, corajosa e imponente, apresentam características exatamente contrárias àquelas que possui a personagem Tertuliano Máximo Afonso. Essa remissão paródica - já que a desinência evoca sujeitos corajosos e de forte postura, atitude contraria à da personagem Tertuliano Máximo Afonso - corrobora nossa ideia de que o nome da personagem revela seus sua identidade.

A personagem histórica Quintus Septimus Florens Tertulianus, em seu projeto cristão de escrita, leva ao cume a apologética latina. Lança também, com genialidade, as bases da patrística ocidental, enfrentando problemas até então complexos do nascente pensamento teológico, tais como a questão trinitária, a questão cristológica e o problema do mal. Segundo consta, o tratado De praescriptione haereticum (escrito por volta do ano 200), foi o documento que inaugurou a patrística latina.

Seus documentos contêm em suas linhas a "primeira e decisiva, se bem que não precisa, formulação ocidental da doutrina ortodoxa sobre a Trindade." (Idem, 1980, p. 879). Paratore ainda nos diz que foi Tertulianus quem fez o cristianismo "falar verdadeiramente a língua latina pela primeira vez". (Idem, 1980, p. 868), e também o declara "fundador genial da patrística latina e verdadeiro criador da linguagem latina cristã" (Idem, 1980, p. 881). Como nos ilumina Paratore, é por meio de Tertulianus que a língua latina cristã estabelece suas bases. Para dar um exemplo, "os termos persona e trinitas, no tratamento do problema da trindade e, por conseguinte, no caminho para a formulação do respectivo dogma, foram um achado do gênio lingüístico de Tertuliano" (Idem, 1980, p. 868). 
Em seus escritos, o apologista criticou a perseguição movida pelos governos e pelos povos contra os cristãos, combateu o paganismo e os movimentos considerados heréticos, principalmente o gnoticismo e defendeu o "Fideísmo" (doutrina segundo a qual as verdades religiosas e morais só podem ser alcançadas pela fé) (Cf. Idem, 1980, p. 868). Por volta de 202, aderiu ao montanismo, seita cristã herética fundada por Montano (que se dizia inspirado diretamente pelo Espírito Santo e profetizava a iminência da segunda vinda de Cristo) ${ }^{63}$.

Tertulianus foi um gênio sombrio que construiu uma obra apologética dentro da doutrina católica e, em dado momento, tomou outro rumo, com tendências algo heréticas, avessas à sua doutrina anterior. Essa mudança é atestada em suas obras: Apologéticas, Sobre a Idolatria, Sobre a Readmissão dos Heréticos e Sobre a Fuga na Perseguição.

A sua vida cheia de contradições e mudanças bruscas faz com que o Tertulianus histórico se aproxime da personagem do romance saramaguiano, afinal os dois são, do ponto de vista do senso comum, pessoas desconcertantes. Além disso, as duas personagens se identificam por destacarem-se em meio à grande multidão e desviarem-se do caminho dito convencional que vinham seguindo para construir uma trajetória particular, única e ascendente. É interessante notar que, assim como a personagem saramaguiana, o Tertulianus histórico também passa por uma grande mudança identitária.

Além disso, a postura do Tertulianus histórico em manter duas perspectivas diferentes (o cristianismo católico e o montanismo) em sua vida reflete diretamente a postura ambígua que a personagem do romance demonstra ter. Como a personagem histórica, Tertuliano Máximo Afonso não se decide em nada. Não sabe se procura ou não seu duplo, não consegue decidir se assiste a um filme ou lê um livro sobre a civilização caldéia e assim por diante. A personagem do romance saramaguiano em questão é totalmente indecisa, sempre entre duas decisões e sem coragem para tomar uma. Um bom exemplo para ilustrar essa contradição é o seu sentimento por Maria da Paz. Ao mesmo

\footnotetext{
${ }^{63}$ "Montano, um frígio do século II, seguido por uma multidão de mulheres excitadas, as assim chamadas profetizas, rejuvenescera a interpretação milenarista do verbo cristão, isto é, a que considerava iminente a chegada do Reino de Deus (...) A heresia montanista representa, portanto, a reaç̧ão extrema à gnose: (...) Montano pregava de novo a iminência da vinda do Reino, sob o signo do Paráclito, do Espírito Santo, que inspirava e guiava directamente os crentes puros, sem necessidade de qualquer intermediário eclesiástico; era a primeira manifestação daquela corrente vigorosa que, durante séculos, alimentará a fé num reinado do Espírito Santo, que haveria de se seguir ao reinado do Filho (Novo Testamento), como este seguira ao reinado do Pai (Antigo Testamento), e que haveria de instaurar efectivamente a caridade e o amor entre os homens" (PARATORE, 1980, p. 878).
} 
tempo em que a evita, Tertuliano Máximo Afonso luta por ela quando entende a proposta de seu duplo, que deseja passar uma noite com ela. Ao mesmo tempo em que ama, Tertuliano Máximo Afonso desiste rapidamente de seu amor. Dessa forma:

(...) Muito bem, irei apresentar-me em carne e osso à sua amiga e contar-lhe-ei o que lhe ocultou por falta de coragem ou qualquer outra razão que só você conhece, Se tivesse aqui uma arma, matava-o, É possível, mas isto não é cinema, meu caro, na vida as coisas são muito mais simples, mesmo quando há assassinos e assassinados, Despeje o saco de uma vez, falou com ela, respondame de uma vez, Falei, sim, pelo telefone, E que lhe disse, Convidei-a para ir hoje comigo ver uma casa de campo que está para alugar, A sua casa de campo, Exactamente, a minha casa de campo, mas fique descansado, quem falou pelo telefone com a sua amiga Maria da Paz não foi António Claro, mas sim Tertuliano Máximo Afonso, Você está doido, que diabólica tramóia é esta, que pretende, Quer que lhe diga, Exijo-o, Pretendo passar esta noite com ela, nada mais. Tertuliano Máximo Afonso levantou-se de rompante e avançou para António Claro de punhos cerrados, mas tropeçou na pequena mesa que os separava e teria ido ao chão se o outro não o tivesse segurado no último instante. Esbracejou, debateu-se, mas António Claro, agilmente, dominou-o com uma prisão rápida de braço que o deixou imobilizado (...) (HD, 2002, p. 277).

Amor e desinteresse caracterizam o sentimento de Tertuliano Máximo Afonso por Maria da Paz. Ao mesmo tempo em que "avança de punhos cerrados" contra aquele que ameaça sua namorada, desiste quando é subjugado pela força de seu duplicado Antonio Claro/Daniel Santa-Clara.

O protagonista do romance possui ainda dois outros nomes, Máximo e Afonso. Se por um lado temos o superlativo absoluto sintético Máximo, vocábulo que significa "o mais alto grau a que e pode chegar", por outro temos Afonso, que se origina do teutônico "nobre; guerreiro; de ânimo combativo" (NASCENTES, 1952, p. 388).

Os dois nomes possuem uma função paródica em relação à identidade da personagem principal. Temos em "Máximo" um vocábulo que expressa grandeza e força. Essa grandeza e força são levadas ao extremo pelo teutônico "Afonso" e pela agudeza do "nobre, combativo", significados que se aglutinam na composição da identidade da personagem. Entretanto, esses vocábulos - Máximo e Afonso - desencantam-se por representarem uma falsidade. Por causa da banalidade em que vive sua existência, os nomes de Tertuliano Máximo Afonso causam estranheza e soam irônicos à personagem que denominam. São paródicos em certo momento. Parecem ironicamente arbitrários e incongruentes com sua imagem; eles se contrapõem ao anonimato e ao embotamento (dentro do plano da narrativa) que Tertuliano Máximo Afonso vive.

Ao soar incomum, a onomástica do protagonista aponta para um dos provérbios presentes em $O$ Homem Duplicado e que nos antecipa que nem tudo correrá bem. "Tem cuidado, vigia-te, quando uma pessoa começa a falsear nunca se sabe até onde chegará” 
(HD p. 125). Tertuliano Máximo Afonso é aquele que tornar-se-á falso. Assumirá a identidade de outro em um processo que "não se sabe até onde chegará".A personagem falsa, pois sendo ela mesma, agirá na pele de um outro eu, passando-se por ele, uma espécie de caos que precisa ser decifrado.

Se os nomes próprios ajudam a traduzir muito do caráter dos personagens, dos seus comportamentos e dos seus anseios, a onomástica também nos permite relacionar o nome do antagonista Antonio Claro/Daniel Santa-Clara com alguns de seus traços psicológicos e comportamentos ao longo da narrativa.

O nome Daniel Santa-Clara é um duplo de António Claro, fato que expressa ser essa personagem um ser duplicado. Como todo duplicado heterogêneo, este também não aceita ser um boneco articulado por seu outro, entrando em conflito com ele e negando o seu original/modelo/criador:

(...) Daniel Santa-Clara, em rigor não existe, é um sombra, um títere, um vulto variável que se agita e fala dentro de uma cassete de vídeo e que regressa ao silêncio e à imobilidade quando acaba o papel que lhe ensinaram, ao passo que esse outro, esse António Claro, é real, concreto, tão consistente como Tertuliano Máximo Afonso, o professor de História que vive nesta casa e cujo nome pode ser encontrado na letra A da lista telefônica (...)” (HD, p. 158, grifos nossos).

Sendo ator, Antonio Claro ganha, por certo período de tempo, variados nomes que correspondem às suas personagens, o que de certo modo esvazia sua nomeação. Se Tertuliano Máximo Afonso expressa certa incongruência em seus diversos nomes, Antonio Claro possui uma multiplicidade em seus nomes.

Duplicado em seu nome - assim como Tertuliano Máximo Afonso -, o ator terá expresso nele certas características identitárias: tanto em sua onomástica artística quanto na verdadeira. O nome artístico, por ser um simulacro - ou seja, algo criado e que ocupa o lugar do verdadeiro - expressa um falseamento da verdade, pois são nomes que identificam algo que inexiste, ou existe apenas por algumas horas e que nem é verdadeiro.

$\mathrm{O}$ mesmo acontece com o nome e sobrenome verdadeiros, pois eles remetem à religiosidade e ao desapego material em um homem que possui desmedida ambição. Há em sua onomástica o bíblico Daniel, do hebraico "Deus é meu juiz; Deus determina, julga" (SARAIVA, 2006, p. 334) e Santa Clara, uma nobre que fez voto de pobreza, tornou-se discípula de São Francisco de Assis e fundou a ordem das Clarissas.

Já o nome batismal António Claro apresenta, por seus significados, outra faceta do nomeado - a do guerreiro que sempre enfrenta seu inimigo. O nome Antonio vem do latim, e significa "inestimável; o que não tem preço; o que enfrenta e faz frente ao inimigo" 
(NASCENTES, 1952, p. 20). Por fim, o vocábulo Claro é ambíguo e pode ser interpretado de formas opostas dependendo do contexto: ora como iluminado, ilustre, ora como lacunar, lugar vazio, clareira (lembremos que Lúcifer provém de luz e, de certa maneira, está contido em Claro). A personagem antagonista apresenta essa mesma ambigüidade do nome. É uma espécie de camaleão, adaptável a situações várias.

As personagens duplicadas são, em essência, descentradas, multiplicadas e fragmentadas a partir dos próprios nomes, um - Daniel Santa Clara/Antonio Claro portador de um pseudônimo artístico e o outro - Tertuliano Máximo Afonso - portador de “(...) apelidos, os quais sendo também nomes próprios, talvez lograssem empurrar para a sombra o nome autêntico, o nome verdadeiro (...)" (HD, p. 49).

Nesta obra de Saramago, o tema do duplo transforma-se em grande metáfora, desvelando a aproximação entre a crise existencial que perturba a personagem principal quando ela descobre seu duplo - e a crise existencial que assola o homem contemporâneo - que se vê sob a ameaça concreta de perder a identidade.

As personagens terminam por não compreenderem que suas identidades só serão formadas por meio da mediação com o outro. A identidade não é algo fixo, mas um processo em constante mutação, fruto de uma negociação de sentidos, de choques, ou de interações culturais. Descobrir o outro é descobrirmo-nos a nós próprios. Os contornos do nosso corpo não limitam as nossas peculiaridades idiossincráticas; não somos seres estranhos a tudo o que escapa à esfera do eu - o eu é o outro, o outro é o eu. Estas noções se baseiam em Todorov (1990, p.11), que inter-relaciona, estreitamente, o eu e o outro. Para ele, encontram-se "apenas separados pelo [meu] ponto de vista segundo o qual eles estão todos lá e só eu estou aqui”.

Assim, ao negarem se duplo, tanto Tertuliano Máximo Afonso quanto António Claro/Daniel Santa-Clara impedem de que sua alteridade seja constituída. O encontro com o $t u$ funda a identidade do eu, na medida em que, frente ao outro, o eu se interroga sobre as suas características naturais e se descentraliza em termos individuais, sociais e étnicos. Esse dialogismo permite, assim, o reconhecimento de si e do outrem, cuja troca de informações ou vivências diferentes enriquece ambos. O constante e variado contato entre eu e outro, leva a que o ego acumule vários altri, e vice-versa. Dessa forma, o conhecimento da alteridade põe em prática a essência social do ser humano.

Essa necessidade do outro é natural ao ser humano. Mal nasce, a criança está inserida num mundo que invade e pelo qual é invadida, iniciando um processo de 
socialização e aprendizagem, durante o qual se modifica e cresce. Torna-se, então, uma do $e u$-natural com o eu-aprendido. Isolado do outro, limitado à realidade aparente e desnudado das aprendizagens as duas personagens protagonistas do romance sentem-se sozinhas, sem contato com seus altri.

Segundo Lacan (Apud AUTHIER-REVUZ, p.134), a noção de uma identidade consolidada, bem definida e definitiva não passa de uma miragem, por isso a necessidade do diálogo constante, sempre em processo. É isso o que realiza o narrador. Passando de ser humano a uma figura discursiva moldada por um discurso social excludente e por seus processos de moldura, esse narrador revela em suas personagens indivíduo isolados, exilados e alienados, que sobrevivem frente a um pano-de-fundo metropolitano, anônimo e impessoal.

Segundo Lacan, "a linguagem é a condição do inconsciente" e "o inconsciente é o discurso do outro", ou seja

(...) o sujeito é compreendido como um efeito de linguagem que ele enuncia e na realidade que o enunciam, o sujeito não é senão da ordem da linguagem na qual ele tem sido acumulado (AUTHIER-REVUZ, 1982, p.137).

Depreendemos então que unidade identitária almejada pelo homem é ilusória; a presença do outro em si mesmo é condição necessária à construção da alteridade e, consequentemente, ao equilíbrio da personalidade, que flana conforme as necessidades sociais - já que o social se impõe ao biológico. O outro é indispensável para a própria existência do ser, assim como para o conhecimento sobre si mesmo.

A descoberta do outro leva tanto Tertuliano Máximo Afonso quanto António Claro/Daniel Santa-Clara a uma crise de identidade, pois as duas personagens não aceitam a existência do outro. São sujeitos do limiar, que, apesar de não aceitarem, necessitam do outro para terem a percepção do eu. O filósofo Clément Rosset (1988, p. 22) que diz que o duplo nos proporciona o fenômeno da paramnésia: o falso reconhecimento, a sensação do "dèjá vu", que sugere uma certeza de já ter visto ou presenciado tal coisa, como se tivéssemos sonhado e nos tornado estranhos a nós mesmos, querendo apenas observar e perceber/buscar aproximações que corroborem o fato/situação. Essa noção de paramnésia se aproxima da ideia de Unheimlich proposta por Freud. No trecho citado, o outro, entendido como ameaça, causa um enfraquecimento do ego, o que gera um desequilíbrio na psique humana, ou, nas palavras de Freud, gera o Unheimlich, um processo de desestabilização e descentrando o sujeito.

Essa desestabilização é comum Na realidade da sociedade liquida, na qual 
O mundo em nossa volta está repartido em fragmentos mal coordenados, enquanto as nossas existências individuais são fatiadas numa sucessão de episódios fragilmente conectados. Poucos de nós, se é que alguém, são capazes de evitar a passagem por mais de uma "comunidade de idéias e princípios", sejam genuínas ou supostas, bem-integradas ou efêmeras, de modo que a maioria tem problemas em resolver (...) a questão da la mêmete (a consequência e continuidade da nossa identidade com o passar do tempo). Poucos de nós, se é que alguém, são expostos apenas a uma "comunidade de idéias e princípios" de cada vez, de modo que a maioria tem problemas semelhantes com a questão da l'ipséite (a coerência daquilo que nos distingue como pessoas, o que quer que seja) (BAUMAN, 2006, p. 18-19).

Entre o eu (Tertuliano Máximo Afonso) e o outro (António Claro/Daniel SantaClara) há uma zona nebulosa de figurações nos quais a alteridade é ofuscada pela inaceitação de um pelo outro, gerada a partir do modo como o eu percebe o outro e também como se percebe com relação ao outro.

Mas como a própria alteridade se constrói necessariamente em função do outro, um identidade lábil e flutuante resultará também numa forma deficitária de relação. A alteridade na qual a mera identificação com o outro substitui a interação, dispensa quase por completo a participação ativa do outro. Mais do que isso, esse outro pode representar uma ameaça a frágil identidade do mesmo. $\mathrm{O}$ outro é fator de desestruturação do mesmo quando eles não se interagem. Por isso os duplos se negam. Eles possuem uma identidade lábil que para se manter se flexibiliza, projetando a metade virtual num duplo que ele não conhece por não ter se aceito. Essa forte identificação negativa com o outro apresenta dois aspectos decisivos: ela impede o eu (ou o mesmo) de perceber o outro como uma identidade independente dele; paralelamente também impede o mesmo de se perceber como uma identidade independente do outro.

Por fim, há que se deixar claro que não há, na narrativa saramaguiana, a tentativa de uma leitura moral. Não temos uma identidade mais positiva. Tanto a identidade coesa do início do romance quanto a fragmentária são postas em evidência. Não temos juízo de valor. O enredo nunca aponta uma das identidades como positiva ou negativa. Há sempre um intercâmbio entre as diferentes identificações. O que fica é a experiência paradoxal da busca pelas identidades, uma vez que o sujeito contemporâneo é essencialmente múltiplo.

Porém, a relação identidade/alteridade no romance, duplo movimento de introjeção/projeção tenta, fracassadamente, substituir o outro externo pela imagem internalizada desse mesmo outro. Isso coincide com a percepção da própria identidade como algo externo e construído. Esse movimento é percebido no romance quando temos, por exemplo 
Boas noites, estava à tua espera, disse o senso comum, Era inevitável que aparecesses, Que ideia é essa de aqui vires, Não armes em ingénuo, sabe-lo tão bem como eu, Vingar-te, desforrar-te, dormir com a mulher do inimigo, já que a tua está na cama com ele, Exacto, E depois, Depois, nada, à Maria da Paz nunca lhe passará pela cabeça que dormiu com o homem trocado, E estes daqui, Estes vão ter de viver a pior parte da tragicomédia, Porquê, Se és o senso comum devias sabê-lo, Perco qualidades nos ascensores, Quando o António Claro entrar amanhã em casa vai ter a maior das dificuldades para explicar à mulher como foi que conseguiu dormir com ela e ao mesmo tempo estar a trabalhar fora da cidade, Não imaginei que fosses capaz de tanto, é um plano absolutamente diabólico, Humano, meu caro, simplesmente humano, o diabo não faz planos, aliás, se os homens fossem bons, ele nem existiria, E amanhã, Arranjarei um pretexto para sair cedo, Esse livro, Não sei, talvez o deixe ficar aqui como recordação. $O$ elevador parou no quinto andar, Tertuliano Máximo Afonso perguntou, Vens comigo, Sou o senso comum, aí dentro não há lugar para mim, Então, até à vista, Duvido (HD, p. 285-86).

Se, na antiguidade clássica, a figura do duplo foi usada por Plauto na representação lúdica de substituição de identidades distintas, na sociedade liquida hodierna representada por Saramago, ela passa a significar, cada vez mais, a divisão e, no limite, até o estilhaçamento da identidade, representado o drama do eu que se alienou de si mesmo. Não há conquista de alteridade, só fragmentação.

Por isso que, quando da morte de seu duplo, Tertuliano Máximo Afonso sente-se novamente perdido. Já não há seu “outro eu”, sua outra projeção para o direcionar. O duplo o deixava no limiar de sua vida, o que lhe obrigava a ter algum tipo de posição. A alteridade se situa, então, no próprio limiar físico do eu.

Temos então que, se a identidade de Anfitrião é sólida, a de Tertuliano Máximo Afonso é liquida. Se em Plauto o sujeito que se desestabiliza retoma sua unicidade ao fim da peça, em Saramago a personagem é aniquilada pela pulverização de sua identidade. Tertuliano Máximo Afonso e seu duplo mostram-se como sujeitos desestabilizados identitariamente por não saberem conviver com o conflito. Elas até tentam, mas sempre são colocadas em xeque novamente. Isso porque não há como concluir a identidade do sujeito contemporâneo. Ela é inconclusiva por natureza, vive no limiar, precisa ser entendida em sua alteridade para ter sustento (mas não sentido).

Também por ser uma narrativa paródica, O Homem Duplicado subverte o texto primeiro - o Amphytruo plautino - tanto textual quanto discursivamente, impondo a suas personagens atitudes e posturas outras que as das personagens do texto plautino que analisamos anteriormente.

Podemos, pois, concluir que é possível um diálogo entre ambas as obras em análise. Confirmamos por meio das análises e comparações que as duas obras, dialogicamente, ora se aproximam, ora se distanciam uma da outra. Esse diálogo transita por marcas, ora mais 
explícitas, ora menos explícitas. O motivo do duplo - assunto eleito para cotejá-las constitui-se um recurso que ressalta a fragmentação das personagens e sua consequente crise de identidade, sendo que na Antiguidade essa fragmentação é apenas conflitiva, elemento reordenado no final da peça, enquanto na contemporaneidade é inconclusiva por natureza. Isso porque não se pode mais pensar em uma Literatura que apresente a visão do todo. Hoje, a Literatura é de fragmentos. O eu não é mais focalizado individualmente, mas como parte do todo fragmentário que a Literatura representa. 


\title{
Considerações Finais: ao modo de conclusão, mas apenas o começo
}

\author{
"Não há mais que ver", sabia que não era assim. O \\ fim duma viagem é apenas o começo doutra. É \\ preciso voltar aos passos que foram dados para os \\ repetir, e para traçar caminhos novos ao lado deles. \\ É preciso recomeçar a viagem. Sempre. O viajante \\ volta já. (VP, 1990, p. 257) \\ Quanto mais te disfarçares, mais te parecerás a ti \\ próprio. (HD, 2002, p. 157)
}

Todo trabalho de análise pode incorrer no risco de deixar perdidas pelo caminho as questões básicas que presidiram ao seu desenvolvimento. Diante de diversos modos de pensar os objetos literários aqui apresentados, tentamos escolher um que contemplasse o percurso analítico-interpretativo que procuramos efetuar de cada obra, somado à intenção que nos movia de visualizar o modo pelo qual um escritor cria um objeto estético que, sem jamais prescindir de seu valor como arte em si, mediatiza a compreensão do homem, de seu mundo, seu tempo e sua história.

Tentamos tomar o cuidado de alinhavar os capítulos de modo que não só um funcionasse como pressuposto do outro, mas também que acabassem todos por conjugar ou reafirmar uma série de dados que nos pareciam linhas de força das considerações que agora se esboçarão. É neste momento que tais linhas mais claramente virão tramar a malha do texto.

$\mathrm{Na}$ trajetória aqui realizada, encontramos, no topos do duplo, subsídios para examinar a questão da identidade apresentada tanto por Plauto quanto por Saramago. Notamos que o conceito de duplo é, em si mesmo, uma resposta ao contexto em que se constrói - o que nos leva a acreditar que cada tempo possui um modo próprio de exprimirse. Buscamos, nos textos eleitos, o princípio estruturador, uma especificidade que nos permitisse visualizar essa relação estreita, dialética e dialógica - essa interação, enfim entre o texto e o mundo.

Para atingir esse ponto de chegada, delimitamos nosso campo de ação: percorremos as veredas que a questão do duplo suscitou no Amphitruo, do escritor latino Plauto, e n'O 
Homem Duplicado, de José Saramago. Evidentemente, trata-se de um recorte que entendemos como significativo e, de certo modo, capaz de sintetizar algumas das constantes desse tema quando tomadas em seu todo. A tematização da questão do duplo e sua relação intrínseca com a problemática da identidade e da alteridade, por outro lado, avultam de tal maneira que é impossível fechar os olhos a elas.

Se, por um lado, essa evidência da questão do duplo facilita sobremaneira o exercício da leitura - pois o dado em questão salta à vista - ela exige, por outro, um elo realmente significativo de relação entre o duplo, a questão identitária e os elementos de intertextualidade, que possibilitem uma interpretação capaz de ser, de alguma maneira, produtiva. Tal processo precisaria oferecer um contributo, ainda que pequeno, à interpretação e à avaliação das obras, para que pudesse, também, estabelecer a especificidade dessa relação na antiguidade clássica e na contemporaneidade, estudo que, apesar de bem realizado por muitos, nos parecia pouco explorado ao se tratar dos dois escritores (Plauto e Saramago) em suas relações.

Refletindo, então, sobre o modo como esses textos se organizam e apoiando-nos nas reflexões teórico-críticas que apontam para as particularidades da identidade, observamos que, no romance de Saramago em pauta, a retomada da questão do duplo traz, embutida em seu âmago, a questão da intertextualidade - traço distintivo desse romance.

Fomos, então, atraídos por esses traços e desafiados a pensar de forma objetiva as possibilidades interpretativas que o Amphytruo plautino e $O$ Homem Duplicado saramaguiano carregam e quais as relações que as duas obras estabelecem entre si.

Assim, partindo da questão do duplo, vimos - no capítulo I de nosso trabalho - que o topos surgiu há muito tempo, na Epopeia de Gilgamesh, sendo retomado em diversas narrativas religiosas subsequentes, tais como no Hinduísmo - a narrativa que conta sobre a natureza do Brahma - ou no Cristianismo - as narrativas de Adão e Eva, Esaú e Jacó etc. Após tal incursão, no detivemos nas concepções filosóficas que apresentam, em suas linhas, a presença da duplicidade - Platão, Nietzsche e Freud - e nas ideias de Carla Cunha e Nicole Fernandes Bravo, que trabalham com conceitos de duplicidade e investigam o desenvolvimento da questão do duplo nos diversos estágios da história.

Após uma pequena reflexão sobre a questão norteadora de nosso trabalho, no capítulo II definimos os conceitos de acréscimo, supressão, inversão e deslocamento para, posteriormente, poder usá-los na análise da peça do escritor latino Plauto. O levantamento dos elementos intertextuais serviu para demonstrarmos como o autor do Amphytruo 
retomou intertextualmente o mito do duplo presente na narrativa mítica de Anfitrião. Constatamos, na peça plautina, que a identidade da personagem Anfitrião - representante do sujeito clássico -, apesar de cindir-se em um determinado momento da peça, é totalmente sólida. Ou seja, mesmo que se reconheça cindido depois que toma conhecimento da sua duplicidade com Júpiter, no final da peça Anfitrião retorna à sua condição anterior, recupera a sua identidade monolítica.

Verificamos ainda que, por meio do processo de aemulatio, Plauto cria uma peça que se diferencia de seu protótipo mitológico, pois insere o novo e renova o mito. Nesse sentido, constatamos que, por meio dos acréscimos, supressões, inversões e deslocamentos, o escritor latino ora renovou, ora inovou e renovou, ora preservou a narrativa mítica, conforme as exigências do texto. Durante nosso percurso analítico, verificamos ainda quais as convenções da época e quais as preocupações que estão expressas ao longo do texto plautino.

No capítulo III, abordamos a forma como o discurso plautino se faz presente no romance saramaguiano, sem deixar de lado outras questões, como a alegoria e os elementos intertextuais - os mesmos acréscimos, supressões, inversões e deslocamentos que analisamos no capítulo referente a Plauto. Ainda neste terceiro capítulo, investigamos também quais as formas de renovação, inovação ou preservação de que Saramago lançou mão n'O Homem Duplicado para retomar o protótipo plautino. Constatamos que, no romance do escritor português, diferentemente do que ocorre na peça, o ser humano já não é mais monolítico, sólido, mas fluido, líquido e cindido. Heterogêneo por natureza.

Por fim, no capítulo IV, analisamos a função do duplo em cada obra, sabendo que é impossível pensar esse topos sem relacioná-lo com a questão da identidade e da alteridade. Metodologicamente, procuramos destacar, dessas duas obras, os fragmentos que concentram a sua pertinência em relação à questão identitária e suas possibilidades de leitura. Buscamos, para isso, instrumentalizar um método interpretativo coerente com a peça de Plauto e o romance de Saramago. Tal aproximação entre as obras fez-nos ver, antes de qualquer outra coisa, o seu trabalho artístico e sua capacidade de expressão.

Finalmente, por intermédio da análise do corpus, apreendemos que, na literatura produzida por Plauto - representante da antiguidade clássica -, o conflito da perda da identidade era apenas pontual, não aberto, sendo o conflito resolvido com uma conclusão fechada, monolítica - marca da duplicidade homogênea. Já na literatura produzida por José Saramago - representante da contemporaneidade -, com frequência esse tipo de perda 
identitária atinge desfechos marcados pela fragmentariedade, o trânsito pelo limiar e a abertura total - marca da duplicidade heterogênea.

Se, na peça plautina, o conflito é instalado e resolvido pelas mãos de Júpiter, n’O Homem Duplicado, por sua vez, há a instauração de uma crise ontológica que, ao ser retomada sob o olhar aquilino de Saramago, produz uma bela metáfora que revela o conflito ontológico vivido pelo ser humano do século XXI.

Percebemos, então, que o romance de Saramago, ao mesmo tempo que remete à questão do duplo, aponta também para outro traço distintivo de sua construção, a paródia e a construção do sentido por ela levada a efeito. Contrariamente ao que possa parecer, a paródia - como nos ensina Hutcheon (cf. 1985, p. 42 ss) - não nega o objeto sobre o qual opera, mas aponta para as suas ambiguidades e virtualidades significativas. O conceito de paródia proposto por Linda Hutcheon - repetição com diferença - faz-nos entender paródia não mais como oposição, como um sentido contrário ao do objeto parodiado. Segundo a teórica americana, a paródia é repetição com distância crítica. Ou seja, ela instala a diferença no seio mesmo das semelhanças, constituindo uma recodificação do passado que não intenta destruir o objeto, mas deformá-lo: dar-lhe uma nova forma capaz de produzir, pela sua indissolubilidade de natureza incontestável, um novo sentido ${ }^{64}$. A paródia configura-se, então, como estratégia discursiva cujo sentido preciso se dá por meio do distanciamento crítico do texto parodiado. Segundo essa visão, ela não se vincula necessariamente ao riso, ao cômico, mas a um movimento tenso e dual, que recupera e desestrutura os textos de que se vale. Cabe aqui observar que, por ser dual, essa estratégia convém à composição de textos que retomam o topos do duplo, produzindo uma consonância perfeita entre tema e mecanismo discursivo.

A solidão humana, o individualismo e a desreferencialização do homem contemporâneo abrigam-se na existência do protagonista Tertuliano Máximo Afonso, um ser perdido, sem direção. Tal fato se coaduna perfeitamente com a declaração que o escritor português faz de suas personagens. Ele diz:

(...) quando afirmo que aquilo que o autor sabe das suas personagens é o passado, quero dizer que do futuro não sabe nada. (...) Nas linhas seguintes que vou escrevendo, não é que se me vá tornando claro, mas de repente há como uma

\footnotetext{
${ }^{64}$ Etimologicamente inclusive, para também significa ao longo de, e isto, ao contrário de implicar contraste, sugere exatamente um acordo, uma cumplicidade entre os objetos. $O$ que instala a distância - que permite a revisão crítica do objeto parodiado, e não a sua negação - é justamente a ironia, a estratégia discursiva de que o gênero mais frequentemente se utiliza.
} 
espécie de necessidade da própria história que necessita que aquela personagem se determine desta ou daquela forma (...) (In: REIS, p. 133).

A personagem, em Saramago, parece remeter à dificuldade de fixidez identitária de qualquer indivíduo no mundo atual. As possibilidades de interpretação do protagonista parecem retratar as próprias estruturas da contemporaneidade, responsáveis pela identificação provisória do homem de hoje.

Já a retomada do tema da duplicidade, em seu caráter mítico e ficcional - por meio do conflito criado pelas personagens duplicadas no romance -, resgata uma maneira metafórica - que teve o seu auge no Romantismo do século XIX - de ilustrar essa condição multifacetada do sujeito da sociedade líquida moderna.

Embora Tertuliano Máximo Afonso muito se tenha empenhado para ver o seu duplo, sucumbe no limiar por medo do encontro. Isso acontece porque cada vez que o eu se aproxima do outro, estes não se aceitam, negam-se um ao outro - ou seja, rejeitam a alteridade - e entram em crise. É esse acontecimento que nos permite fazer uma reflexão sobre a personalidade cindida, a fragmentação do sujeito e a multiplicidade de personae. Tudo isso nos possibilita identificar - ancorados nas considerações de Hall e em nossa interpretação d'O Homem Duplicado (capítulo IV da dissertação, que comprova nossos argumentos) - a identidade múltipla como uma das características do sujeito contemporâneo, que se contrapõe ao sujeito clássico, uno e monolítico - representado na peça plautina.

A multiplicidade de identidades é muitas vezes representada no romance de Saramago pelo deparar-se diante de um espelho. Esse ato instaura a tensão entre o espelho e o seu reflexo, que, como ensinou Lacan, expressa a tensão entre o eu e o outro.

O livro O Homem Duplicado, de José Saramago apresenta sua autonomia e pode ser entendido por um público que desconheça Plauto. Mas uma leitura com o conhecimento do escritor latino certamente pode tornar mais rica a apreciação da arte da imitação e modalizações desenvolvidas pelo escritor português. Por exemplo, em Anfitrião, a personagem Sósia apresenta quase um prenúncio do que ocorrerá com Tertuliano Máximo Afonso, pois, se o escravo padece diante de seu duplo Mercúrio, o professor de História também sofrerá no confronto com António Claro.

Considerando os resultados da comparação, foi possível refletir sobre o processo de criação (modus faciendi) de Plauto e José Saramago, especialmente no que diz respeito ao caráter híbrido das fontes de ambos: de um lado, um misto de textos clássicos (Comédia 
nova grega e a poética aristotélica, para Plauto; Plauto e a poética aristotélica, para Saramago), e, de outro, manifestações que expressam a conjuntura cultural de cada época (a questão da identidade em cada um dos textos analisados).

O papel feminino nas obras foi outra vertente que analisamos, detendo-nos particularmente em quatro personagens: Alcmena, Carolina, Helena e Maria da Paz. Elas foram interpretadas por meio das suas alusões mitológicas, históricas e bíblicas e, com isso, possibilitaram a retratação da figura feminina pelos dois escritores, além de levar-nos a matizar uma das visões da expressão feminina nos séculos IV a.C. e XXI.

Também notamos que toda a história do duplo é reveladora da existência de uma ruptura entre as categorias do eu e do outro, que se manifesta quer positiva, quer negativamente. Em consequência disso, o eu anseia pelo preenchimento do vazio existencial mediante a busca do outro. Essa questão é apresentada tanto por Plauto quanto por Saramago de forma distinta e em épocas diferenciadas.

Em relação às ocorrências desse tema nos dois textos analisados, podemos constatar, em Plauto, o seu uso para fins cômicos, estruturando a peça. Já em Saramago, esse mesmo tema apresenta-se como um caso de oxímoro, que consiste na combinação e conciliação de elementos paradoxais, revelando que a conciliação de contrários é possível, como vemos principalmente no final d'O Homem Duplicado.

Finalmente, o exame a que procedemos nos levou a concluir que o duplo é um tema onipresente em diversas instâncias da produção literária, clássica, moderna ou contemporânea. No entanto, outros assuntos ainda ficaram por ser estudados tanto no Amphytruo quanto em $O$ Homem Duplicado. No primeiro, temos, por exemplo, a questão da escravidão, a falta de valoração e voz da personagem Alcmena, ou a função dos servos na peça, aspectos que apenas tangenciamos, mas não desenvolvemos por se desviarem do assunto principal de que tratamos. Além disso, faltaria ainda um comentário mais específico sobre as formas e escolhas da tradução, a questão da versificação ou do gênero palliata.

Quanto ao romance, temos o problema da alegoria, no qual não nos detivemos o suficiente. O foco narrativo e sua especularidade, presentes na narrativa, a estrutura trágica ou a narrativa em abismo são outros aspectos aqui ignorados por não caberem dentro dos limites deste trabalho.

Sabemos que as obras analisadas sempre serão maiores que o analista, sendo impossível esgotar sua gama de possibilidades. Permanece em nós, como vontade e desejo, 
a esperança de dar continuidade, com maior fôlego, ao estudo dos livros aqui abordados, tentando dar conta desses diversos matizes que não foram exploradas.

Esperamos que este trabalho, não obstante suas limitações, seja mais uma contribuição para os demais pesquisadores da temática do duplo, quer nas obras literárias componentes do corpus, quer nas muitas outras oferecidas pela arte em geral. 


\section{REFERÊNCIAS BIBLIOGRÁFICAS}

\section{A - Autores trabalhados}

PLAUTE. Amphitryon. Asinaria. Aulularia. Texte établi et traduit par A. Ernout. Paris: Les Belles Lettres, 1970.

PLAUTO. O Anfitrião. Trad. Carlos Alberto Louro Fonseca. Lisboa: Edições 70, 1993. . Os Menecmos. In: . Comédias. Trad. Jaime Bruna. São Paulo: Cultrix, 1978.

PLAUTO \& TERÊNCIO. A Comédia Latina. Tradução e notas de Agostinho da Silva. Rio de Janeiro: Edições de Ouro, 1969.

SARAMAGO, José. As Opiniões que o DL Teve. Lisboa: Caminho, 1974. . Objecto Quase. Lisboa: Moraes, 1977. . O Ouvido. In: et al. Poética dos Cinco Sentidos. Lisboa: Bertrand, 1979a. . A Noite. 2.ed. Lisboa: Caminho, $1979 \mathrm{~b}$.

- Que farei com este livro? 2.ed. Lisboa: Caminho, 1980. . Viagem a Portugal. Lisboa: Círculo de Leitores, 1981. . Os Poemas Possíveis. 2. ed. Lisboa: Caminho, 1982. . Deste Mundo e do Outro. 3. ed. Lisboa: Caminho, 1985. . Levantado do Chão. Rio de Janeiro: Bertrand, 1988. . A segunda vida de Francisco de Assis. Lisboa: Caminho, 1989. . Os Apontamentos: Crônicas Políticas. 2.ed. Lisboa: Caminho, 1990. . O Ano da Morte de Ricardo Reis. São Paulo: Companhia das Letras, 1994. . Provavelmente Alegria. 2.ed. Lisboa: Caminho, 1995a. . A Jangada de Pedra. São Paulo: Companhia das Letras, 1995b. . A bagagem do Viajante: crônicas. 2.ed. Lisboa: Caminho, 1996a. . Ensaio sobre a Cegueira. São Paulo: Companhia das Letras, 1996 b. . Memorial do Convento. 17. ed. Rio de Janeiro: Bertrand, 1996c. . Cadernos de Lanzarote. Vol. I (Diários I, II e III). São Paulo: Companhia das Letras, 1997a.

. Terra do Pecado. 7. ed. Lisboa: Caminho, $1997 \mathrm{~b}$. . Todos os Nomes. São Paulo: Companhia das Letras, 1998. 
. Cadernos de Lanzarote. Vol. II (Diários IV e V). São Paulo: Companhia das

Letras, 1999a.

. Folhas Políticas. Lisboa: Caminho, 1999b.

. In nomine Dei. São Paulo: Companhia das Letras, 2000a.

. A Caverna. São Paulo: Companhia das Letras, 2000 b.

. O Evangelho segundo Jesus Cristo. São Paulo: Companhia das Letras, 2000c.

. A maior Flor do mundo. São Paulo: Companhia das Letrinhas, 2001a.

. História do Cerco de Lisboa. São Paulo: Companhia das Letras, 2001b.

. Manual de Pintura e Caligrafia. São Paulo: Companhia das Letras, 2001c.

. O Homem Duplicado. São Paulo: Companhia das Letras, 2002.

. O Conto da Ilha Desconhecida. São Paulo: Companhia das Letras, 2003 b.

. Ensaio sobre a Lucidez. São Paulo: Companhia das Letras, 2004.

. As Intermitências da Morte. São Paulo: Companhia das Letras, 2005a.

. Don Giovanni ou o dissoluto absolvido. São Paulo: Companhia das Letras, 2005b.

. As pequenas Memórias. São Paulo: Companhia das Letras, 2006.

. O Ano de 1993. São Paulo: Companhia das Letras, 2007.

. A Viagem do Elefante. São Paulo: Companhia das Letras, 2008.

. O Caderno. São Paulo: Companhia das Letras, 2009a.

. Caim. São Paulo: Companhia das Letras, 2009b.

\section{B - Geral}

ALTHIER-REVUZ, J. Hétérogénéité montrée et hétérogénéité constitutive: élements pour une approche de l'autre dans le discours. In: DRLAV-Revue de Linguistique, $\mathrm{n}^{\mathrm{o}}$ 26, 1982, pp. 91-151.

ARISTÓTELES. Poética/Peri Poihtikhs. Trad. Eudoro de Souza (Ed. Bilíngüe). São Paulo: Ars Poética, 1992.

. Arte Retórica e Arte Poética. Trad. Antônio Pinto de Carvalho. São Paulo:

Difusão Européia do Livro, 1964.

ARMSTRONG, Karen. Breve Historia do Mito. Trad. Celso Nogueira. São Paulo:

Companhia das Letras, 2005.

BAKHTIN, Mikhail M./VOLOCHINOV, V. N. Marxismo e Filosofia da Linguagem.

Trad. de Michel Lahud e Yara Frateschi Vieira. 6. ed. São Paulo: HUCITEC, 1992. 
BAKHTIN, Mikhail. Problemas da Poética de Dostoievski. Trad. Paulo Bezerra. Rio de Janeiro: Forense Universitária, 1998.

. Estética da Criação Verbal. Trad. Paulo Bezerra. São Paulo: Martins Fontes, 2006.

BARTHES. Roland. Roland Barthes por Roland Barthes. Trad. Leyla Perrone-Moisés. São Paulo: Cultrix, s.d.

BAUMAN, Zigmunt. Modernidade Liquida. Trad. Carlos Alberto Medeiros. Rio de Janeiro: Jorge Zahar, 2005.

. Identidade. Trad. Carlos Alberto Medeiros. Rio de Janeiro: Jorge Zahar Ed., 2006.

Bíblia de Jerusalém. 5a edição. São Paulo: Edições Paulinas, 1992.

BERRINI, Beatriz. Ler Saramago: O Romance. Lisboa: Caminho, 1998.

BOUCHÉ, Claude. Lautréamont du lieu commun à la parodie. Paris: Larousse, 1974.

BRANDÃO, Junito de Souza. Dicionario Mítico-Etimológico. 3 ed. Petrópolis: Vozes, 2000. 2 vols.

BRAVO, Nicole Fernandes. Duplo. In: BRUNEL, Pierre et al. Dicionário de Mitos Literários. $3^{\text {a }}$ ed. Rio de Janeiro: José Olympio, 2002.

BRUNEL, Pierre et al. Dicionário de Mitos Literários. $3^{\mathrm{a}}$ ed. Rio de Janeiro: José Olympio, 2002.

CARDOSO, Zélia de Almeida. Figuras femininas em Plauto: convencionalismo e originalidade. In: Lingua e Literatura. 19: p. 29-37, 1991.

. O mito de Anfitrião na dramaturgia latina. In: Anais do IX encontro nacional da ANPOLL, vol. I. Caxambu: João Pessoa-PB, 1995. p. 352-62.

. A literatura latina. São Paulo: Martins Fontes, 2003.

CERDEIRA, Teresa Cristina. José Saramago: entre a história e a ficção, uma saga de portugueses. Lisboa: Publicações Dom Quixote, 1989.

CICERON. Brutus. Texte établi et traduit par Jules Martha. Paris: Las Belles Lettres, 1966. CIRLOT, Juan-Eduardo. Dicionário de Símbolos. Lisboa: Moraes, 1984.

CITRONI, Mario et all. Literatura de Roma Antiga. Trad. Isaías Hipólito e Margarida Miranda. Lisboa: Fundação Calouste Gulbenkian, 2006.

CUNHA, Antonio Geraldo da. Dicionário etimológico Nova Fronteira da língua portuguesa. Rio de Janeiro: Nova Fronteira, 1986.

CUNHA, Carla. Duplo. In: CEIA, Carlos. E-Dicionário de Termos Literários. http://www2.fcsh.unl.pt/edtl/verbetes/D/duplo.htm. Consultado em 10/07/08. 
ECO, Umberto. Obra aberta. $2^{\mathrm{a}}$ ed. Trad. Giovanni Cutolo. São Paulo: Perspectiva, 1971. . Sobre os espelhos. In: . Sobre os Espelhos e outros ensaios. Trad. Beatriz

Borges.Rio de Janeiro: Nova Fronteira, 1989. P. 11-37.

ELIADE, Mircea. Mefistófeles e o andrógino. Trad. Ivone Castilho Benedetti. São Paulo:

Martins Fontes, 1991.

EURÍPEDES. As Bacantes. Trad. Trajano Vieira. São Paulo: Perspectiva, 2003.

FERREIRA, Aurélio Buarque de Holanda. Dicionário da Língua Portuguesa. 3 ed. Rio de Janeiro: Nova Fronteira, 1999.

FREUD, Sigmund. O estranho. In: . Edição Standard Brasileira das Obras

Psicológicas Completas de Sigmund Freud. Rio de Janeiro: Imago, 1976. v.XVII, pp. $237-$ 68.

O estranho. In: . Edição Standard Obras Completas de Sigmund Freud versão eletrônica. Rio de Janeiro, Imago (edição eletrônica em CD-ROM).

GENETTE, Gerard. Introdução ao Arquitexto. Lisboa: Vega, 1986.

. Palimpsestos (excertos). Trad. Luciene Guimarães e Maria Antonia Ramos

Coutinho. Belo Horizonte: Faculdade de Letras, 2006. Disponível em

http://www.letras.ufmg.br/labed/download/palimpsestosmono-site.pdf. Consultado em 08/06/2009.

Gilgamesh. Trad. Maysa Monção Gabrielli. São Paulo: Editorial Cone Sul, 1998.

GRIMAL, Pierre. Dicionário de Mitologia Grega e Romana. Trad. Victor Jabouille. 2 ed. Rio de Janeiro: Bertrand Brasil, 1993.

GUÉRIOS, Rosário Farâni Mansur. Dicionário Etimológico de Nomes e Sobrenomes. São Paulo: Editora Ave Maria, 1973.

HACQUARD, Georges. Dicionário de Etimologia Grega e Romana. Trad. Maria Helena Trindade Lopes. Porto: Edições Asa, 1996.

HALL, Stuart. A Identidade Cultural na Pós-modernidade. $2^{\mathrm{a}}$ ed. Rio de Janeiro: DP\&A, 1998.

HANNS, Luiz Alberto. Dicionário comentado do Alemão de Freud. Rio de Janeiro: Imago, 1996.

HARVEY, Paul. Dicionário Oxford de Literatura Clássica. Trad. Mário da Gama Kury. Rio de Janeiro: Jorge Zahar Editor, 1998.

HESÍODO. Teogonia: a origem dos deuses. Trad. Jaa Torrano. São Paulo: Iluminuras, 1991. 
HOFFMANN E. T. A. O homem de areia. In: CALVINO, Ítalo (org.). Contos fantásticos do século XIX: o fantástico visionário e o fantástico cotidiano. Trad. Luiz A. de Araújo. São Paulo: Companhia das Letras, 2001. p. 49-81.

HORÁCIO. A Arte poética. Trad. Dante Tringali. São Paulo, Musa: 2000.

HOUAISS, Antônio. Dicionário Houaiss da Língua Portuguesa. Rio de Janeiro: Objetiva, 2001 .

HUTCHEON, Linda. Uma Teoria da Paródia. Trad. Teresa Louro Pérez. Lisboa: Edições $70,1985$.

Poética do Pós-Modernismo: História, Teoria e Ficção. Trad. Ricardo Cruz. Rio de Janeiro: Imago, 1991.

JAEGER, Werner. Paidéia. A Formação do Homem Grego. Trad. de Artur M. Parreira.

São Paulo: Martins Fontes, 1999.

JOLLES, André, Formas Simples: legenda, saga, mito, adivinha, ditado, caso, memorável, conto, chiste. Trad. Álvaro Cabral. São Paulo: Cultrix, 1976.

KIEFER, Charles. Borges que amava Estela e outros duplos. Porto Alegre: Mercado Aberto 1995.

KOTHE, Flavio. Parodia \& Cia. In: Tempo Brasileiro (Sobre a Paródia), 62, jul-set./1980.

KRISTEVA, J. Introdução à Semanálise. Trad. de Lúcia Helena França Ferraz. São Paulo: Perspectiva, 1974.

LAUSBERG, Heinrich. Elementos de Retórica Literária. Trad. R.M. Rosado Fernandes. Lisboa: Fundação Calouste Gulbenkian, 1972.

MEZAN, Renato. Identidade e Cultura. In: . A vingança da Esfinge. São Paulo:

Editora Brasiliense, 1988.

MINER, Earl. Poética Comparada: um ensaio intercultural sobre teorias da literatura.

Trad. Angela Gasperin. Brasília: Editora UNB, 1996.

MOISÉS, Leila-Perrone. Literatura comparada, intertexto e antropofagia. In:

Flores da escrivaninha. São Paulo: Cia das Letras, 1990. p. 91-99.

MUCCI, Latuf Isaías. Andrógino. In: Carlos. E-Dicionário de Termos Literários. www.fcsh.unl.pt/edtl/ahtm, consultado em 10/08/2009.

NASCENTES, Antenor. Dicionário Etimológico de Língua Portuguesa. Rio de Janeiro: Livraria Francisco Alves, 1952.

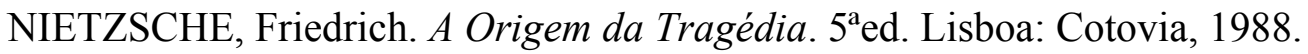
. A Origem da Tragédia, $5^{\mathrm{a}}$ ed. Trad. de Álvaro Ribeiro. Lisboa: Guimarães 
Editora, 1989.

. A Origem da Tragédia (ou Helenismo e Pessimismo). Trad. Jacó Guinsburg. $2^{\mathrm{a}}$ ed.

São Paulo: Cia. das Letras, 1992.

PARATORE, Ettore. História da Literatura Latina. Trad. Manuel Losa, S. J. Lisboa:

Fundação Calouste Gulbenkian, 1980.

PAVIS, Patrice. Dicionário de Teatro. Trad. Jacó Guinsburg et al.. São Paulo:

Perspectiva, 1999.

PETERLINI, Ariovaldo José. As Ressurgências de Anfitrião no teatro do Ocidente. In: Anais do IX encontro nacional da ANPOLL, vol. I. Caxambu: João Pessoa-PB, 1995. p. 319-46.

PLATÃO. Diálogos. Trad. Albertino Pinheiro. São Paulo: Cultrix, s.d.

RANCIÈRE, Jacques. A partilha do sensível / estética e politica. Trad. Mônica Costa

Netto. São Paulo: EXO experimental / Ed. 34, 2005.

RANK, Otto. O Duplo. Trad. Mary B. Lee. Rio de Janeiro: Coeditora Brasílica, 1939.

REIS, Carlos. O homem diante do espelho. In: Jornal de Letras, ano XXI, nº 838, de 13 a 26 de novembro de 2002.

SARAIVA, Francisco R. dos Santos. Dicionário Latino-Português. 12ª Ed. Rio de Janeiro: Livraria Garnier, 2006.

SEIXO, Maria Alzira. Lugares da ficção em José Saramago. Lisboa: Imprensa Nacional, 1999.

The Upanishads. Translated by Alistair Shearer \& Peter Russell; photographs by Richard Lannoy. London Boston: Unwin Paperbacks, 1989.

TODOROV, Tzvetan. Le príncipe dialogique. Paris: Seuil, 1981. Introdução à literatura fantástica. Trad. Maria Clara Correa Castello. 3. ed. São Paulo: Perspectiva, 1985.

VERNANT, Jean-Pierre. Mito e Religião na Grécia Antiga. Trad. Joana Angélica d'Avila Melo. São Paulo: WMF Martins Fontes, 2006.

WELLECK, René \& WARREN, Austin. Teoria da Literatura. Trad. Mira-Sintra. 4. ed. Publicações Europa-América, 1971.

WILDE, Oscar. O Retrato de Dorian Gray. Trad. Januário Leite. Lisboa: Portugália, 1945. ZIFF, Paul. Semantic Analysis Ithaca. Chicago: Cornell University Press, 1996. 


\section{BIBLIOGRAFIA}

ABELAIRA, Augusto. Anfitrião, outra vez. Lisboa: Moraes Editores, 1980.

ADORNO, T. A posição do narrador no romance contemporâneo. In: Os Pensadores

(Benjamin, Horkheimer, Adorno, Habermas). 2. ed. São Paulo: Abril Cultural, 1983. p. 269-73.

AGUIAR e SILVA, V. M. Teoria da Literatura. $3^{\text {a }}$ ed. Coimbra: Almedina, 1979.

AGUILERA, Fernando Gómes. José Saramago: a consistência dos Sonhos, cronobiografia. Trad. António Gonçalves. Lisboa: Caminho, 2008.

ARIAS, Juan. José Saramago: o Amor Possível. Trad. Rubia Prates Goldoni. Rio de Janeiro: Manati, 2003.

AUGÉ, Marc. Não-lugares: Introdução a uma antropologia da supermodernidade. Campinas: Papirus, 1994.

AUTHIER-REVUZ, J. Heterogeneidade(s) enunciativa(s). Trad. de Celene Cruz e João W.

Geraldi. In: Cadernos de Estudos Lingüísticos, 19, pp. 25-42. Campinas: IEL Unicamp, 1990.

BAKHTIN, Mikhail. Questões de Literatura e de Estética: a teoria do romance. Trad.:

Aurora Fornoni Bernadini. 4. ed. São Paulo: Unesp, 1998.

BAYET, Jean. Literatura Latina. Barcelona: Editorial Ariel, 1996.

BERMAN, Marshall. Tudo que é sólido desmancha no ar: a aventura da modernidade.

Trad.: Carlos Felipe Moises, Ana Maria L. Ioriatti. 2. ed. São Paulo: Cia. das Letras, 2007.

BERRINI, Beatriz. José Saramago, uma homenagem. 3. ed. São Paulo: Educ, 1999.

BORGES, Jorge Luis \& GUERRERO, Marguerita. El Libro de los Seres Imaginarios.

Buenos Madrid: Aliança Editorial, 1967.

BRAIT, B. Ironia em perspectiva polifônica. Campinas: Editora da Unicamp, 1996.

BRIDI, Marlise Vaz. Modernidade e pós-modernidade na ficção portuguesa

Contemporânea. Revista Todas as Letras. Universidade Presbiteriana Mackenzie: São

Paulo, 2005.

CAMPELO, J. N. A ficção da ficção em $O$ ano da morte de Ricardo Reis. Revista Letras. Curitiba: Editora da UFPR, n. 34, p. 39-43, 1985.

CAMPOS, J. A. Segurado. Em torno de Anfitrião. In: Classica. 24, p. 101-110, 2002.

CARDOSO, Isabella Tardin. Ars Plautina. Tese (Doutorado em Literatura Latina).

Faculdade de Filosofia, Letras e Ciências Humanas. São Paulo: Universidade de São 
Paulo, 2005.

CARRATORE, Enzo Del. Plauto e a helenização de Roma: alguns aspectos. In: Alfa. 2223: p. 5-43, 1976-77.

Colóquio - Letras, Lisboa, n 151/152, jan.- jun. 1999.

COMPAGNON, Antoine. O Trabalho da Citação. Trad. Cleonice P. B. Mourão. Belo Horizonte: Editora UFMG, 2007.

COSTA, Aída. Temas Clássicos. São Paulo: Cultrix, 1978.

COSTA, Horácio. O lugar de José Saramago na literatura contemporânea. Folha de São Paulo. 27.04.1988. Ilustrada. p.8. 27.04.1988.

Sobre a pós-modernidade em Portugal. Saramago revista Pessoa. Colóquio Letras. (Lisboa), n.109, p.41-8, 1989. . José Saramago: o período formativo. Lisboa: Caminho, 1997. . José Saramago, o despertar da palavra. In: Revista CULT, n 17, 1998, p.24.

FERREIRA, Aurélio Buarque de Holanda. Dicionário da Língua Portuguesa. $3^{\mathrm{a}} \mathrm{ed}$. Rio de Janeiro: Nova Fronteira, 1999.

FIGUEIREDO, Guilherme Oliveira de. Um Deus dormiu lá em Casa. Peça em três Atos. Rio de Janeiro: Serviço Nacional de Teatro, 1973.

FONSECA, Carlos Alberto Louro. Introdução. In: PLAUTO. O Anfitrião. Trad. Carlos Alberto Louro Fonseca. Lisboa: Edições 70, 1993.

FRANÇOIS, Fredric. Dialogismo e romance ou Bakhtin visto através de Dostoiévski. In: BRAIT, Beth. Bakthin: dialogismo e construção de sentidos. Campinas: Unicamp, 2005. GIDDENS, Anthony. As consequências da modernidade. São Paulo: EDUNESP, 1991. GOMES, A.C. A voz itinerante. São Paulo: Edusp, 1993.

HALL, Stuart. Quem precisa de identidade? In: SILVA, Tomaz Tadeu da (Org.).

Identidade e diferença: a perspectiva dos estudos culturais. Petrópolis: Vozes, 2000. p.103-133.

HORÁCIO. A Arte Poética. Trad. Dante Tringali. São Paulo, Musa: 2000.

HUCHTEON, Linda. Teoria e política da ironia. Trad.: Júlio de Jeha. Belo Horizonte: UFMG, 2000.

JENNY, Laurent. A estratégia da forma. In: et al. Intertextualidades. Trad. C. C.

Rocha. Coimbra: Almedina, 1979. P. 5-49.

Jornal Independente. Lisboa, 17 de Maio de 1991. 
JUNG, Carl Gustav. Tipos psicológicos. Trad. Álvaro Cabral. Rio de Janeiro: Zahar editores, 1967.

KERÉNYI, Karl. Os deuses gregos. Trad. Octávio Mendes Cajado. São Paulo: Cultrix, 1996.

LANDOWSKI, Eric. Presenças do outro. São Paulo: Perspectiva, 2002.

LOPONDO, Lílian. Saramago segundo Terceiros. São Paulo: Humanitas/FFLCH-USP, 1998.

LOTMAN, Iuri. A estrutura do texto artístico. Trad.: Maria do Carmo Vieira Raposo, Alberto Raposo. Lisboa: Estampa, 1978.

LOURENÇO, Antonio Apolinário. Crônica do Ano da Peste. In: Diário de Lisboa. Lisboa, 28 de janeiro de 1988.

MAFFESOLI, Michel. Elogio da razão sensível. Trad.: Albert C.M. Stukenbruck.

Petrópolis: Vozes, 1998.

. O Instante Eterno. O retorno do trágico nas sociedades pós-modernas. Trad.

Rogério de Almeida e Alexandre Dias. São Paulo: Zouk, 2003.

MAHEIRIE, Kátia. Constituição do sujeito, subjetividade e identidade. Revista Interações, jun. 2002, v. 7, n. 13, p. 3144. Disponível em: http://pepsic.bvspsi.org.br/scielo.php?script. Acessado em: 23/03/ 2010.

O Estado de São Paulo, Caderno 2, Ano XVII, n. 5.634, 2 de novembro de 2002, D1. OLIVEIRA FILHO, Odil José. Carnaval Convento: Intertextualidade e Paródia em José Saramago. São Paulo: EDUNESP, 1993.

PICCHIO, Luciana Stegagno. José Saramago: A lição da pedra. In: Colóquio - Letras, Lisboa, n 151/152, jan.- jun. 1999, p. 13-19.

POE, Edgar Allan. William Wilson. In: . Histórias Extraordinárias. Trad. Brenno

Silveira et al. São Paulo: Abril Cultural, 1981. O Gato Preto. In: . Histórias Extraordinárias. Trad. Brenno Silveira et al. São Paulo: Abril Cultural, 1981.

RIBEIRO, Raquel de Sousa. Saramago e Bruegel: a cegueira e suas visões. In: ANAIS DO XI ENCONTRO REGIONAL DA ABRALIC. São Paulo, 2007. Disponível em: www.abralic.org.br/enc2007/anais/41/1087.pdf. Consultado em: 02/05/ 2009. SEIXO, M. A. Alteridade e auto-referencialidade no romance português de hoje (A propósito das obras de J. Saramago, M. Cláudio e Maria Gabriela Llansol). In: . A 
palavra do romance. Ensaios de genologia e análise. Lisboa: Livros Horizonte, 1986. p. $21-7$.

. O Essencial sobre José Saramago. Lisboa: Imprensa Nacional - Casa da Moeda, 1987.

SILVEIRA, Francisco Maciel. Saramago: Eu-próprio, o Outro. Aveiro: Ed. da Universidade de Aveiro, 2007.

SPALDING. Tassilo Orpheu. Pequeno Dicionário de Literatura Latina. São Paulo:

Cultrix, 1977.

STAIGER, Emil. Conceitos Fundamentais de Poética. Rio de Janeiro: Tempo Brasileiro, 1969.

STEVENSON, Robert Louis. O estranho caso do Dr. Jekyll e de Mr. Hide. Trad.: Pietro Nasseti. 7. ed. São Paulo: Ática, 1996. 